\title{
SO DARK THE CON(TU) OF MAN: THE QUEST FOR A SOFTWARE DERIVATIVE WORK RIGHT IN SECTION 117
}

\author{
Lateef Mtima*
}

\begin{abstract}
Computer software programs have various unique characteristics as copyrightable works. Among other things, unlike traditional copyrightable works, it is necessary to copy and often to modify software programs in order to use them. In addition, as functional works, the development of additional programs, an overarching goal of copyright protection, often requires the "efficient reuse" of protected elements of preexisting programs. The copyright law currently provides an ambiguous and contradictory response to these issues. While section 117 of the Copyright Act provides program users with the privilege to prepare "adaptations" of copyrighted programs, section 106 reserves to copyright holders the exclusive right to prepare derivative versions of their programs. This article proposes that user adaptation privileges can be distinguished from, and reconciled with, copyright holder derivative work exclusive rights by virtue of the impact that a user-prepared adaptation will have upon the market for the original copyrighted program: "market benign" adaptations should be treated as privileged adaptations, while "market pernicious" adaptations should be treated as derivative works and therefore, subject to the rights of the copyright holder in the original program. In addition, the "practical-use versus market-impact" balancing rationale used to draw the foregoing distinction can also be used to reconstruct the traditional derivative work right into a narrower "software derivative work right." This software derivative work right would limit the copyright holder's exclusive right to that of creating derivative programs that are likely to compete with, or otherwise have an undue impact on the market for, the original copyrighted software program. This would enable judicial recognition of a new "public derivative work privilege" to create non-competitive derivative software programs from preexisting works.
\end{abstract}

* Copyright (C) 2007, Lateef Mtima, Professor of Law and Director, Institute of Intellectual Property and Social Justice, Howard University School of Law. I would like to thank Steven Jamar, Carey Lening, and Greg Vetter for their extremely helpful comments on various drafts of this article. I would also like to thank Ron Jones, HUSL '08, Lyndsey Kuykendall, HUSL '07, John Montevideo, '08, and Monica Ullagaddi, HUSL '07, for their excellent research assistance. Finally, I would like to thank Dean Kurt L. Schmoke and HUSL for research and resource support. Any errors are my own. 


\section{INTRODUCTION}

For more than a quarter century, the extension of copyright protection to computer software programs has presented a panoply of legal and social utility challenges. The courts, practitioners, and members of the software industry have struggled to fit this unique form of intellectual property into the substantive copyright framework, particularly the copyright system of exclusive rights. One of the most nettlesome problems in this regard is the application of the copyright holder's exclusive right to prepare derivative versions of her work.

When applied to software programs, the derivative work right does not accommodate the principal objectives of the copyright law as traditionally understood. The traditional derivative work right fails to account fully for the utilitarian nature of software programs and the extent to which subsequent programs must necessarily incorporate certain expressive aspects of preexisting works. Accordingly, this article proposes that the derivative work right should be narrowed in its application to software programs, and that section 117 of the Copyright Act, which explicitly balances the interests of software users and copyright holders, can be invoked to bring about this result. Relying upon section 117 as well as derivative work right jurisprudence, the software copyright holder's exclusive dominion over derivative versions of her work should be limited to precluding unauthorized versions which unfairly compromise the commercial market for the original work, such as where the derivative version is amenable to commercial distribution in direct competition with the original program. Consequently, software users would obtain a "public privilege" to develop derivative versions of copyrighted software programs so long as the unauthorized versions do not unduly impact the commercial market for the original program.

Narrowing the derivative work right in connection with computer software programs advances overarching copyright social policy while maintaining the principal author incentive objectives that underlie the derivative work right. In addition, the corollary creation of a public derivative work privilege further implements the software-user versus copyright-holder balancing policies embodied in section 117. This, in turn, facilitates the beneficial use of software programs. Finally, such a public derivative work privilege is consistent with the fair use doctrine as codified in section 107 of the Copyright Act. 


\section{The Software Square Peg}

As numerous commentators have observed, the "uneasy fit" of computer software programs into the copyright regime is rooted in the very nature of software programs as a socially useful form of intellectual property. Unlike the artistic works traditionally protected by the copyright law, such as novels and songs, software programs are primarily utilitarian in nature, meaning that the salient purpose of a software program is to undertake a task as opposed to expressing aesthetic ideas. Thus, the social policy goals of the copyright law - the stimulation of aesthetic interpretation, expression, and cultural advancement and enlightenment - are not immediately compatible with the utilitarian nature of and concomitant benefits presented by computer software programs.

Further, the innately digital format of software programs is directly antagonistic to the specific author incentive mechanism employed by the copyright regime. The secular incentives provided to copyright holders under the copyright law are embodied within the enumerated exclusive rights - that is, the express reservation of specific uses of a copyrighted work to the copyright holder. These exclusive rights include the right to reproduce and/or distribute the copyrighted work, as well as the right to create derivative versions of the work. Because works in digital format are easily duplicated, distributed, and/or revised, however, it is extremely difficult to enforce even the most fundamental exclusive rights and protections afforded to software developers under the copyright law.

\section{The Roundest Hole-The Derivative Work Right}

Of all the exclusive rights, however, perhaps the most difficult to apply to computer software programs is that of the exclusive right to prepare derivative versions of a copyrighted work. In general, the derivative work right reserves to the copyright holder the right to use the constituent expressive elements of her work, such as the specific characters or plot devices in a novel, in subsequent or alternative creative works, settings, and formats. At the same time, the public remains free to create wholly original characters and/or creative works that are stimulated or inspired by the copyright holder's overall work and the specific characters, plot devices, and ideas contained therein.

The difficulties in applying copyright protection to software programs are particularly prominent in the application of the derivative work right in connection with these works. First, as a utilitarian work, the principal purpose 
of a software program is to accomplish particular tasks. Accordingly, in light of the overarching social policy goals of the copyright law, copyright protection should inspire and facilitate the development of additional, and in particular, more efficient programs to accomplish the same and/or other tasks. Given that there are typically a limited number of ways in which to efficiently accomplish a task, however, it will often be socially desirable that subsequent programmers incorporate some aspects of the first programmer's specific approach in the development of their own software programs.

In other words, whereas "start from scratch" is a laudable social directive in encouraging artistic expression, it can be counterproductive in facilitating utilitarian endeavors. The creation of more efficient software programs as well as programs intended to undertake different tasks - which collectively represent the social policy objective of copyright protection in this context-requires not only the inspiration provided by the example of preexisting programs, but in the interest of efficiency, some later programs must also incorporate specific expressive elements of preexisting programs. Such incorporation, however, contravenes the derivative work right. While the copyright doctrines of merger and scènes à faire provide some relief in this regard, they do not assure optimal socially beneficial software program development. Accordingly, the utilitarian nature of software programs, and certain of the benefits to be derived therefrom, are pragmatically incompatible with the property right and incentive mechanisms embodied within the derivative work right.

Second, the innately digital format of software programs presents a formidable challenge to enforcement of the derivative work right. Because software programs are easily revised and even disseminated without the copyright holder's knowledge or consent, few practical obstacles exist to prevent the surreptitious creation and distribution of unauthorized derivative versions of copyrighted software programs.

Finally, as if the foregoing intrinsic characteristics of computer software programs were not enough, one further challenge exists to the application of the derivative work right to such works: the proper construction of 17 U.S.C. $\S 117$. Section 117 was enacted to accommodate some of the unique characteristics of software programs as copyrightable works. For example, the end user must load a software program onto a computer to access it. In addition, because of differences in computer languages, operating systems, and personal computer formats, software programs are not always "ready to use" on an individual computer and may require some modifications to enable their proper use. In short, unlike traditional copyrighted works, it is often not possible for the public to enjoy the use and benefit of software programs 
without in engaging in one or more of the exclusive rights reserved to the owner of the copyright therein.

Consequently, Congress amended the copyright statute and enacted section 117 to provide the public with some necessary exemptions from the enumerated exclusive rights. Among other things, section 117 provides that the user of a software program is allowed to make input, access, and certain other kinds of copies of the program without violating the copyright holder's exclusive reproduction right. In addition, section 117 authorizes the user to make "adaptations" of a software program when changes are needed to engage in the ordinary use of the program, such as when modifications are made to a program to enable it to work on an individual computer system.

This latter exemption, the user's ability to make adaptations of software programs, adds the final wrinkle in the application of the derivative work right to computer software programs. While section 117 authorizes software users to make necessary adaptations of software programs, it offers no guidance as to how to distinguish this user "adaptation privilege" from the copyright holder's exclusive derivative work right. In other words, how far can a user go in "adapting" a copyrighted software program before her revisions result in the creation of a derivation work in derogation of the copyright holder's exclusive derivative work right?

Invoking and Inverting Section 117: Reconciling the Adaptation Privilege and the Derivative Work Right

Although section 117 interjects additional considerations into the software derivative work right analysis, when properly construed, the adaptation versus derivative work interface provides the basis for a socially responsible application of the derivative work right in connection with software programs. While section $117(1)$ creates an ambiguity with respect to the distinction between adaptations and derivative works, section 117(2) explicitly prohibits the distribution of adaptations to third parties without the permission of the copyright holder. Thus, section 117 is best regarded as a congressional initiative to reconcile the public interest in the broadest use of software programs with the conflicting commodification incentives of the copyright framework. Through section 117, the copyright law facilitates the socially beneficial use of software programs, and by conterminously prohibiting distribution of the adaptations prepared pursuant to its provisions, it also reaffirms one of the chief property rights afforded under the copyright law - the preservation of the commercial market(s) for the copyrighted work. 
This conceptualization of section 117 signifies a substantive demarcation between permissible user section 117 adaptations and impermissible user section 106 derivative works. Fully embracing the foregoing practical-use versus market-preservation balancing rationale, proper section 117 adaptations can be defined as revised programs which (i) have been prepared in order to engage in the proper use of the original program, and (ii) do not impair the copyright holder's exclusive right of distribution or articulated pragmatically, do not unduly compromise the commercial market for the original program. Where the software user's modification activities unduly impact the copyright holder's commercial market interests, however, such as where the resulting work is amenable to commercial distribution in direct competition with the original program, the unauthorized work should not be evaluated as a section 117 adaptation, but rather as an unauthorized derivative version of the original program which may usurp the copyright holder's derivative work right.

\section{Using Section 117 to Narrow the Software Derivative Work Right}

While the practical-use versus market-preservation balancing rationale articulated above might at first appear to diminish the rights of software users, a closer look reveals that, overall, it expands them. This is because, in addition to providing a basis for distinguishing between adaptations and derivative works, the practical-use versus market-preservation balancing rationale can be utilized to narrow the derivative work right for software programs in general.

The proliferation of software programs is a compelling social objective underlying the extension of copyright protection to such works. Congress determined that this objective would be both served and properly counterbalanced by the promulgation of specific mechanisms to preserve software developers' commercial market interests. The development of additional and better software programs would seem to be a social imperative of comparable significance to that of assuring the proliferation and use of existing programs. Given that Congress decided that the public's ability to use existing programs should be counterbalanced by the copyright holder's commercial market interests, however, it seems reasonable to extrapolate that the development of additional and/or better programs should be similarly counterbalanced. Embracing section 117 as representative of a broader software-user versus copyright-holder social balancing policy, the "safe harbor" for privileged adaptations can be extended to unauthorized derivative works: in addition to preparing proper adaptations, the software-using public should be permitted the privilege to create derivative versions of copyrighted 
software programs up to the point that such works unduly compromise the commercial market interests of copyright holders in their underlying works.

A departure from the traditional application of the derivative work right, which precludes all unauthorized derivative work versions of copyrighted works, merely acknowledges that if the overarching social objectives of the copyright law are to be achieved, the unique nature of software programs as copyrighted works mandates a more tailored and socially cognizant application of the derivative work right. Moreover, this restriction of the copyright holder's dominion is consistent with the author incentive objectives which fuel the derivative work right: it secures the broadest legitimate commercial market for the copyright holder. Finally, a more narrow derivative work right — and a corollary public derivative work privilege — for software programs is not only supported by section 117 but is also consonant with the fair use doctrine. In short, a narrower derivative work right for software programs serves the broadest societal interests by harmonizing a "copyright constituent CON-fluence" of competing copyright interests.

\section{Road Map}

Part I of this article briefly summarizes the principal challenges presented by the extension of copyright protection to computer software programs. These challenges include the adaptation of a legal regime designed to stimulate artistic expression in order to stimulate the proliferation and use of utilitarian creative works, as well as the efficacious protection and enforcement of the copyright holder's exclusive rights, particularly the exclusive right to prepare derivative works.

Part II analyzes section 117 as a congressional initiative for balancing the competing interests of software users and owners of copyrights in computer software programs. Part II reviews the leading decisions interpreting section 117 and charts the jurisprudential framework for applying the statute that has evolved from these cases, including the judicial determination that the section 117 user adaptation privilege overlaps with and encompasses some aspects of the copyright holder's derivative work right.

Part III explores section 117's express deference to the distribution right, specifically as a means for substantively distinguishing between section 117 adaptations and section 106 derivative works. Part III offers that where the nature of the modifications made pursuant to section 117 qualify the resulting work for treatment as both a derivative work and an adaptation, the revised program's dual status should not automatically divest it of the special protections afforded under section 117. Instead, in balancing the public 
interest in the maximum exploitation of the utilitarian benefits of computer software as against the legitimate commercial exploitation interests of the copyright holder, the resulting work should be denied section 117 adaptation status and be treated as a derivative work only to the extent that the unauthorized work unduly compromises the commercial market interests of the copyright holder in the original program.

Finally, Part IV applies the section 117 practical-use versus commercialmarket-preservation balancing rationale articulated in Part III in support of narrowing the derivative work right for software programs as a general matter. Part IV offers that permitting copyright holders to preclude all unauthorized derivative versions of their software programs, even where such versions do not compromise the copyright holders' legitimate commercial market interests, undermines the social utility objectives that underlie the copyright law. Instead, identifying the copyright holder's legitimate "copyright market" interests, and concomitantly restricting her software derivative work rights to the preservation of those interests, is a more socially responsible application of the derivative work right.

Consequently, whether the defendant software user has possibly overstepped the boundaries of her section 117 adaptation privileges, or has undertaken the modification of a copyrighted program for purposes wholly unrelated to section 117, the dispositive infringement issue remains the same: what is the impact of the unauthorized work on the commercial market for the original software program? Accordingly, a software user would be allowed the privilege to create both section 117 adaptations and derivative versions of copyrighted software programs to the extent that such adaptations and unauthorized derivative works do not unduly compromise the commercial market rights attendant to the underlying computer software programs.

\section{Subverting the Utilitarian Side: The Extension of Copyright Protection to Computer Software Programs}

The Copyright Act provides that "[c]opyright protection subsists ... in original works of authorship [once] fixed in any tangible medium of expression . . . from which they can be perceived, reproduced, or otherwise communicated ...." Copyright protection was expressly extended to computer software programs as "original works of authorship" on guidance from the National Commission on New Technology Uses of Copyrighted

1. 17 U.S.C. $\S 102(2006)$. 
Works (CONTU), which in 1979 recommended that software programs be given the same copyright protection afforded traditional literary and artistic works. ${ }^{2}$ This recommendation provided the basis for the Computer Software

2. See National Commission of New Technological Uses of Copyrighted Works, Final Report and Recommendation (1978), reprinted in 5 Copyright, Congress \& Technology: The Public Record 32-36 (Nicholas Henry ed.,1980) [hereinafter CONTU Final Report]; 1 Melville B. NimMer \& DAVid NimMer, NimMer ON COPYRight § 2.04[C], at 2-51 n.21 (2006) ("Note that the Act of December 31, 1974 (Pub. L. 93-573, 88 Stat. 1873), Title II established the National Commission on New Technological Uses of Copyrighted Works (CONTU), which was charged, inter alia, with studying and making recommendations for copyright legislation relating to the creation of new works by the application or intervention of . . . automatic systems. ... The CONTU Final Report concluded that it was clearly the intent of Congress to include computer programs within the scope of copyrightable subject matter in the Act of $1976 \ldots$... The Report further recommended that such protection for computer programs should be continued, with appropriate changes in 17 U.S.C. § 117. The changes recommended by CONTU were adopted in the Computer Software Copyright Act of 1980 (Pub. L. 96-517, 94 Stat. 3015)." (footnotes omitted) (marks omitted)); Christina M. Reger, Let's Swap Copyright For Code: The Computer Software Disclosure Dichotomy, 24 Loy. L.A. ENT. L. Rev. 215, 223-24 (2004) ("Neither the 1909 Act, nor the 1976 Act, originally articulated computer programs as protectable subject matter. In fact, the 1976 Act did not even include computer programs in the list of protectable works. However, prior to passing of the 1976 Act, Congress chartered the National Commission on New Technological Uses of Copyright Works ('CONTU') to examine new technologies and determine how to most appropriately revise the current intellectual property laws to provide protection for these technologies. CONTU's mission was to incorporate computer programs and information technology into the existing menu of intellectual property protection. After extensive research, CONTU recommended that the principal protection for computer software should reside within copyright law, notwithstanding that copyright law did not protect an 'idea, procedure, process, system, method of operation, concept, principle or discovery.' Congress responded by implementing the recommendations offered by CONTU into the 1980 amendments to the 1976 Act." (footnotes omitted)); see also Ralph S. Brown, Eligibility for Copyright Protection: A Search for Principled Standards, 70 Minn. L. Rev. 579, 581 (1985) (“Congress has interpreted the term 'writings' generously when fulfilling its constitutional mandate. The first copyright statute, of 1790, listed maps and charts ahead of books in its short list of protected 'writings.' In the 1976 thorough revision of copyright law, the constitutional protection of 'writings' became a protection that 'subsists . . . in original works of authorship fixed in any tangible medium of expression, now known or later developed, from which they can be perceived, reproduced, or otherwise communicated, either directly or with the aid of a machine or device.' This language insures that copyright is receptive to new technologies, provided that fixation and communication are possible." (footnotes omitted)). 
Protection Act of $1980,{ }^{3}$ and software programs have since been treated the same as literary works for purposes of the copyright law. ${ }^{4}$

As is the case with respect to traditional copyrighted works, copyright law protects the programmer's creative expression of the software program's intended function. ${ }^{5}$ Thus, much the same as specific sentences or overall plot devices are among the protected elements in a novel, literal source and object code, as well as overall structure and organization, are protected elements in a software program. ${ }^{6}$

3. See H.R. REP. No. 96-1307, pt. 1, at 23 (1980), reprinted in 1980 U.S.C.C.A.N. 6460, 6482; see also Deborah F. Buckman, Copyright Protection of Computer Programs, 180 A.L.R. FeD. 1, 17 (2002) ("In 1976, Congress enacted a complete revision of copyright law, representing Congress' response to the startling developments recently made in technology and science. This new Act, known as the Copyright Act of 1976 and codified in 17 U.S.C.A. $\S \S 101 \mathrm{et} \mathrm{seq.,} \mathrm{represents} \mathrm{the} \mathrm{existing} \mathrm{statutory} \mathrm{authority} \mathrm{for}$ copyright. At the time of its enactment in 1976, Congress still remained hesitant about expanding the law, regarding computers in particular, pending further study by the Commission On New Technological Uses of Copyright Works, (CONTU). The final CONTU report in 1978 led to the adoption of an amendment to the Act in 1980, which expressly included computer programs as proper subjects of copyright. The Amendment did this by including in the definitional section of copyrightable subject matter a definition of 'computer program' and also by replacing $\S 117$ of the 1976 Act with a new section limiting the exclusive rights given to 'authors' in copies of computer programs. The Act now defines a computer program as 'a set of statements or instructions to be used directly or indirectly in a computer in order to bring about a certain result.' Computer programs are entitled to copyright protection as 'literary works,' within the definition, in $\S 101$ of the Act, of 'works, other than audiovisual works, expressed in words, numbers, or other verbal or numerical symbols or indicia, regardless of the nature of the material objects, such as books, periodicals, manuscripts, phonorecords, film, tapes, disks, or cards, in which they are embodied." (footnotes omitted)).

4. See generally Wall Data Inc. v. L.A. County Sheriff's Dep't, 447 F.3d 769, 776-77 (9th Cir. 2006); Lexmark Int'l, Inc. v. Static Control Components, Inc., 387 F.3d 522, 533 (6th Cir. 2004); Gen. Universal Sys. v. Lee, 379 F.3d 131, 142-143 (5th Cir. 2004); Graham v. James, 144 F.3d 229 (2d Cir. 1998); Gates Rubber Co. v. Bando Chem. Indus., 9 F.3d 823 (10th Cir. 1993).

5. $\quad$ See 17 U.S.C. $§ 102$ (b) (2006); Feist Publ'ns, Inc. v. Rural Tel. Serv. Co., 499 U.S. 340, $345-50$ (1991); Meridian Project Sys., Inc. v. Hardin Constr. Co., 426 F. Supp. 2d 1101, 1112 (E.D. Cal. 2006); see also Greg R. Vetter, The Collaborative Integrity of Open-Source Software, 2004 UTAH L. REV. 563, 578 ("When developing software, one arranges a composite of instructions, data, and interfaces in a sequence and hierarchy that will produce a particular desired computing outcome. This instructional composite bears the label 'software' or 'computer program."' (footnote omitted)); Reger, supra note 2, at 218-19 ("Computer software is a set of instructions or data that a computer follows, acts upon, lists, or displays for the user's benefit. This includes computer programs, documentation, databases, and user interfaces. Software subdivides into three components: literal code, non-literal code, and structural components, all of which enable the program to produce its desired results. Literal code, deemed protectable under the 1976 Act, is the written text and computer instructions. Non-literal code is the translation or sequencing of such text to achieve a desired result. Its protection is the source of much litigation and commentary." (footnotes omitted)).

6. See, e.g., Reger, supra note 2; Andrew LaFontaine, Note, Adventures in Software Licensing: SCO v. IBM and the Future of the Open Source Model, 4 J. Telecomm. \& High Tech. L. 449, 454 (2006) ("Software is available in two forms: source code and object code. Source code is the form in which software is originally written - it is human readable such that a programmer can understand it and modify 
Accordingly, under copyright law, software programmers enjoy essentially all of the property rights and protections afforded to authors of traditional literary works. ${ }^{7}$ In general, copyright holders may preclude, and/or

it if she wishes. Object code is a machine readable form that the source code must first be translated (or 'compiled') into before it will run on a computer." (footnotes omitted)); Lexmark Int'l, Inc., 387 F.3d at 533 ("[Copyright protection extends] to a computer program's object code (the binary code—a series of zeros and ones - that computers can read) and its source code (the spelled-out program commands that humans can read)."); Note, Copyright Protection of Computer Program Object Code, 96 Harv. L. Rev. 1723, 1724-25 (1983) ("Computers can 'understand' (that is, execute) only programs in 'machine language' - the lowest level. A machine language instruction is a cluster of ' 0 ' and ' 1 ' symbols called 'bits,' which are the only symbols recognized by digital computers. A program consisting of a sequence of machine language instructions is referred to as 'object code.' To make it easier for humans to read and write programs, two 'higher' levels of languages exist. The first level is 'assembly language.' Assembly language instructions consist of alphanumeric labels rather than bits. To be executed by the computer, the alphanumeric instructions must be translated into their corresponding clusters of bits by another computer program known as an 'assembler.' At the next level are 'high-level' computer languages, such as FORTRAN or COBOL, that employ English-like words and syntax and are therefore easier to use and understand than assembly or machine language. Each high-level instruction is the equivalent of several assembly or machine language instructions. A computer program known as a 'compiler' translates highlevel programs into the corresponding object code. Programs written in assembly or high-level languages are referred to as 'source programs' or 'source code."' (footnotes omitted)). See generally Computer Assocs. Int'l, Inc. v. Altai, Inc., 982 F.2d 693, 703 (2d Cir. 1992); Control Data Sys., Inc. v. Infoware Inc., 903 F. Supp. 1316, 1322 (D. Minn. 1995); Vetter, supra note 5, at 588 ("Source code's literary nature became more pronounced as computing technology advanced. Software programming languages became more sophisticated and elegant. They began to increasingly resemble human languages. This suggested copyright protection, including protection of the source code as a literary work.").

7. See, e.g., Wall Data Inc., 447 F.3d at 776-77; Lexmark Int'l, Inc., 387 F.3d at 533; Gen. Universal Sys., 379 F.3d at 142-143; Graham, 144 F.3d at 229; Gates Rubber Co., 9 F.3d at 823; Recursion Software, Inc. v. Interactive Intelligence, Inc., 425 F. Supp. 2d 756, 766 (N.D. Tex. 2006). See generally Mark A. Lemley \& David W. O’Brien, Encouraging Software Reuse, 49 StAN. L. Rev. 255, 277-79 (1997) ("Software copyright infringement law has developed over several generations of cases, each redefining the scope of copyright protection for elements of program code. The first generation of cases established that direct copying of the precise coding of computer software constituted infringement.... Whelan Associates v. Jaslow Dental Laboratories [797 F.2d 1222 (3d Cir. 1986)] ushered in a second generation of cases in which courts began to protect application program code on the basis of nonliteral infringement - the duplication of a program's organization without the literal copying of any significant portions of the code. . . More recently, in the third generation of software copyright cases, courts have refused to apply the Whelan standard. Led by Computer Associates International v. Altai, Inc. [982 F.2d 693 (2d Cir. 1992)] in 1992, these courts have advanced a much narrower 'abstraction-filtrationcomparison' test to determine whether two programs are substantially similar. The Altai analysis limits the scope of copyright protection of nonliteral expression by requiring that elements of the program that are dictated by efficiency or external factors and elements taken from the public domain be filtered out. . . . A final set of disagreements over software copyright law came to the fore in 1995, when the First Circuit reversed a series of related lower court decisions concerning the menu command structure of the Lotus 1-2-3 spreadsheet program. The First Circuit declined to follow Altai's abstraction-filtration-comparison test, instead holding that the Lotus 1-2-3 menu command hierarchy is an entirely unprotectable 'method of operation' under 17 U.S.C. $§ 102$ (b). The majority did not treat the case as an issue of compatibility between programs, as Judge Boudin advocated in his concurrence. This decision placed the First Circuit 
recover for, any unauthorized copying of their works. ${ }^{8}$ Under copyright law, "copying" includes several specific uses or rights reserved exclusively to the copyright holder, including the right to reproduce the work, the right to distribute the work, and the right to prepare derivative versions of the work. ${ }^{9}$

at odds with several other circuits that had read the "method of operation' language more narrowly." (footnotes omitted)).

8. 17 U.S.C. $\S \S 106,501 ; 2$ Paul Gold ste in, Goldstein on Copyright $\S 9.1$, at 9:1 to :2 (3d ed. 2006) ("Section 501(a) of the Copyright Act states the rule on copyright infringement with deceptive simplicity: 'Anyone who violates any of the exclusive rights of the copyright owner as provided by sections 106 through 121 or of the author as provided in section 106(a), or who imports copies or phonorecords into the United States in violation of section 602, is an infringer of the copyright or right of the author, as the case may be.' The legal reality is more complex. To prevail in an action for copyright infringement, a plaintiff must prove that it owns the right or rights in issue and that the defendant's conduct infringes one or more of these rights. To prove infringement, the plaintiff must show (1) that the defendant copied from the plaintiff's work and (2) that, taken together, the elements copied amount to an improper appropriation. To prove copying, the plaintiff must show directly or by inference that the defendant mechanically copied the plaintiff's work, such as by photocopying it, or that the defendant had the plaintiff's work in mind when he composed the allegedly infringing work." (footnotes omitted)); see also MGE UPS Sys., Inc. v. Fakouri Elec. Eng'g, Inc., 422 F. Supp. 2d 724, 735 (N.D. Tex. 2006) ("To prove actionable copying, [a plaintiff] must show that [the defendants] had access to [the software] and that the works are substantially similar. [The plaintiff] does not need proof of actual, direct copying to prove copyright infringement; thus, indirect proof that [the defendants] had access to [the software] is sufficient." (citation omitted)); Expediters Int'1 of Wash., Inc. v. Direct Line Cargo Mgmt. Servs., Inc., 995 F. Supp. 468, 475 (D.N.J. 1998) (“To establish a prima facie case of copyright infringement, a plaintiff must prove: (a) ownership of a valid copyright in the infringed work; and (b) copying by defendant (or a violation of another of the exclusive rights provided to a copyright owner by the copyright Act)."); Control Data Sys., Inc., 903 F. Supp. at 1320-21 (D. Minn. 1995) ("If the plaintiff is unable to produce direct evidence of copying, it may instead rely on indirect evidence that first, the defendant had access to the copyrighted material, and second, that there are 'probative similarities' between the copyrighted program and the allegedly infringing material. 'Ultimately, to prove factual copying, the plaintiff must come forward with sufficient evidence that a reasonable factfinder, taking together the evidence of access and the similarities between the programs, could find that the second work was copied from the first." (citation omitted)).

9. See 17 U.S.C. $\S \S 106(1)-(3)$; Harper \& Row, Publishers, Inc. v. Nation Enters., 471 U.S. 539, 546-47 (1985) ("Section 106 of the Copyright Act confers a bundle of exclusive rights to the owner of the copyright. Under the Copyright Act, these rights - to publish, copy, and distribute the author's work - vest in the author of an original work from the time of its creation. In practice, the author commonly sells his rights to publishers who offer royalties in exchange for their services in producing and marketing the author's work." (footnote omitted)). See generally Feist Publ'ns, Inc., 499 U.S. at 361; Avtec Sys., Inc. v. Peiffer, 21 F.3d 568, 571 (4th Cir. 1994); Ford Motor Co. v. Summit Motor Prods., Inc., 930 F.2d 277, 291 (3d Cir. 1991); Meridian Project Sys., 426 F. Supp. 2d at 1111-12; i-Systems, Inc. v. Softwares, Inc., No. 02-1951, 2004 WL 742082 at *7-8 (D. Minn. Mar. 29, 2004); I. Fred Koenigsberg, Copyrights, in Understanding Basic Copyright Law 2002, at 137 (PLI Pats., Copyrights, Trademarks, and Literary Prop., Course Handbook Series No. G-710, 2002). The copyright holder can recover compensatory or statutory damages upon establishing a case of infringement; that is, unauthorized engagement in any of the exclusive rights. Injunctive relief may also be obtained to prevent further incursions upon the copyright holder's rights. "'A preliminary injunction enjoining a copyright infringement serves the public interest by furthering the goals of individual effort and fair competition.' . . . Although . . . it is in the public interest to encourage the competition and the development of new computer programs, it is not in the public 
The application of copyright protection to computer software programs, however, has often been far easier said than done. ${ }^{10}$ Unlike the aesthetic novels, songs, and paintings traditionally protected by copyright law, software programs are principally utilitarian works - that is, works whose primary purpose is to perform a particular task or tasks. ${ }^{11}$ Accordingly, many of the

interest to permit the marketing of a program that infringes on the intellectual property rights of another." Control Data Sys., Inc., 903 F. Supp. at 1326 (quoting E.F. Johnson Co. v. Uniden Corp. of Am., 623 F. Supp. 1485, 1491 (D. Minn. 1985)).

10. See, e.g., Whelan Assocs., 797 F.2d at 1222; Computer Assocs. Int'l, Inc., 982 F.2d at 712 ("Generally, we think that copyright registration - with its indiscriminating availability - is not ideally suited to deal with the highly dynamic technology of computer science. Thus far, many of the decisions in this area reflect the courts' attempt to fit the proverbial square peg in a round hole.”); Gates Rubber Co., 9 F.3d at 834; N.Y. Times Co. v. Tasini, 533 U.S. 483 (2001); Lotus Dev. Corp. v. Borland Int'l, Inc., 49 F.3d 807, 814-15 (1st Cir. 1995). See generally Pamela Samuelson et al., A Manifesto Concerning the Legal Protection of Computer Programs, 94 CoLum. L. Rev. 2308, 2349-50 (1994)("Even after Congress decided to make copyright protection available to programs, their utilitarian character has made it difficult for courts to apply traditional copyright doctrines to computer programs and to make distinctions that are legally as well as technically meaningful. Courts have also frequently found the traditional tests for copyright infringement to be unsatisfactory or unworkable as applied to computer programs, and have consequently undertaken to develop new (and often inconsistent) tests for judging infringement in software cases. However, copyright has no ready answers to many questions posed in software cases because it has never before regulated competition in technological fields. The very vocabulary and metaphorical structure of copyright law makes it difficult to talk about programs in a meaningful way." (footnotes omitted)); Ruth Okediji, Givers, Takers, and Other Kinds of Users: A Fair Use Doctrine For Cyberspace, 53 FLA. L. REv. 107, 109 (2001) ("For some time, the debate surrounding copyright law and new technology primarily centered on the copyrightability of new technologies - that is, the feasibility of extending copyright protection to new technologies, such as computer software. Although Congress ostensibly decided the issue over two decades ago, conceptual questions still remain and scholarly discourse continues about the viability and wisdom of extending copyright protection both to new technologies and the innumerable ways that the technology fosters exploitation of copyrighted works." (footnote omitted)); Donna L. Lee, Reverse Engineering of Computer Programs Under the DMCA: Recognizing a "Fair Access" Defense, 10 MARQ. Intell. Prop. L. Rev. 537, 543-49 (2006); Lateef Mtima, Protecting and Licensing Software: Copyright and Common Law Contract Considerations, The Computer \& Internet. Law., Mar. 2005, at 13.

11. See 4 Nimmer \& Nimmer, supra note 2, § 13.03[F][1], at 13-132 ("All computer programs are intended to cause the computer to perform some function."); Samuelson et al., supra note 10, at 2316-17 ("The view of programs as texts has been widely adopted in the legal community. While conceiving of programs as texts is not incorrect, it is seriously incomplete. A crucially important characteristic of programs is that they behave; programs exist to make computers perform tasks. Program behavior consists of all the actions that a computer can perform by executing program instructions. Among the behaviors commonly found in word processing programs, for example, are copying text, deleting text, moving text from one place to another, and aligning margins.... Programs often compete on the basis of behavior; advertisements routinely list the capabilities ... . a program has that its competitors do not. Advertisements for tax preparation programs, for example, may emphasize the variety of tax forms they can handle (that is, the variety of tax-preparation behaviors the program is capable of producing). Behavior is not a secondary by-product of a program, but rather an essential part of what programs are. To put the point starkly: No one would want to buy a program that did not behave, i.e., that did nothing, no matter how elegant the source code 'prose' expressing that nothing." (footnotes omitted)); Reger, supra note 2, at 221 ("As a written work with a utilitarian purpose, computer programs deride and defy categorization in the 


\author{
beneficial characteristics of software programs are more amenable to \\ protection under utilitarian intellectual property regimes, such as that provided \\ by the federal patent law. ${ }^{12}$
}

present library of intellectual property protection. Despite this paradox, Congress designated copyright law as the method of protection for computer program, or code, bringing it under the umbrella of federal protections. Consequently, works are protected for what they express (the tangible medium) and not how the expression results in operation (the utilitarian purpose)." (footnotes omitted)). I am grateful to my colleague Steven Jamar for the cautionary admonition to avoid drawing this line too rigidly. As Professor Jamar suggests, some digital works that may be considered software programs, such as a digital painting, would not be considered "utilitarian" in the ordinary sense. While this observation is sound, there is also room for philosophical disagreement. When a painting is digitized, is this "program" utilitarian or artistic in nature? It depends upon whether one regards the " $0 \mathrm{~s}$ " and " $1 \mathrm{~s}$ " as "Lichtenstein dots" comprising an illustration, or as a utilitarian component to be combined with a computer to "produce" an artistic product, much the same as film and a camera are combined to produce a picture. Resolving such philosophical questions is beyond the scope of this article. For purposes of the present discussion, software programs are regarded primarily as utilitarian works, protected under an intellectual property regime constructed with primarily aesthetic works in mind.

12. See 35 U.S.C. $\S \S 101-103,112$ (2006); 1 Donald S. Chisum, Chisum on Patents $§ 1.01$, at 1-6 to -8 (2006) ('The Constitution and the statutes limit patents to 'useful arts,' but there is no express statement in the patent statutes that all inventions in all the useful arts are covered. Nevertheless, the four old classes of statutory subject matter have proved to be quite flexible. They have been interpreted so as to cover most of the new technologies that evolved during the last 200 years. . . Patents for processes, machines, manufactures and compositions of matter are generally called 'utility' patents." (footnotes omitted)); Bradford L. Smith \& Susan O. Mann, Innovation and Intellectual Property Protection in the Software Industry: An Emerging Role for Patents?, 71 U. CHI. L. REv. 241, 256-57 (2004) ("[T]here are good reasons to believe that patent law may offer a superior regime to both copyright and trade secret law for protecting at least certain elements of software programs. First, in contrast to copyrights and trade secrets, a prerequisite for patent protection is that the inventor must disclose a clear and precise description of his or her invention, thereby promoting the goals of technological disclosure and IT product transparency. Second, whereas copyrights protect only the author's original expression of an idea, patents protect the actual invention, not just a single implementation of it. Thus, patent protection enables software developers to share key technologies with partners, customers, and others (even competitors) without significantly diminishing the developer's ability to prevent second comers from slavishly copying those aspects of a software program that are truly novel and innovative... Third, as many courts have recognized, patent law offers a distinct form of protection - and serves different policy goals - than does copyright law. Patents seek to promote technological progress by giving exclusive rights in discrete inventions in exchange for early public disclosure of the invention. ... The patent examination process is designed to ensure that legal protection will extend only to technologies that are truly novel, useful, and non-obvious." (footnotes omitted)). It is also worth noting that in the early history of software program distribution, developers sought protection under the trade secret law. The proliferation and mass distribution of software, however, eventually rendered trade secret protection an impractical alternative. See, e.g., Vetter, supra note 5, at 587 ("The industrial organization and technological deployment of software before and into the 1970s called for trade secret protection. Computers were not ubiquitous. Large organizations were the primary users. Software was developed with languages that were, by today's standards, rather 'low-level.' As a result, those languages required a highly specialized and skilled artisan to deal with the computer program. More importantly, software was often distributed under tight contractual control, often with negotiated agreements. . . . As computer technology and software languages evolved, however, other protection regimes supplemented trade secret law. Increasing standardization in languages and operating systems 
In general, utilitarian inventions which represent an "inventive" or "nonobvious leap" over the state of the art are eligible for patent protection, provided that the inventor discloses the details of her invention, so that the public might learn from her work and then build upon it, thereby promoting the progress of the utilitarian arts and sciences. ${ }^{13}$ In exchange for this contribution to the learning in her field, the patent law reserves to the patent holder the exclusive right to make, use, or sell her invention for a statutorily specified period of time..$^{14}$ Through this "negative exclusive right," the patent

heightened the possibility that programmers could reverse engineer object code, obtaining in the process a close proxy for the original source code. Thus, the secret status of trade secrets embodied in software was increasingly in jeopardy of discovery, which would foil trade secret protection."). Still other scholars have argued in favor of sui generis protection for software programs. See, e.g., Samuelson et al., supra note 10, at 2310 ("[W] $[\mathrm{Wile}$ copyright law can provide appropriate protection for some aspects of computer programs, other valuable aspects of programs, such as the useful behavior generated when programs are in operation and the industrial design responsible for producing this behavior, are vulnerable to rapid imitation that, left unchecked, would undermine incentives to invest in software development.").

13. U.S. Const. art. I, § 8, cl. 8; 35 U.S.C. $\S \S 101-103$; see CHIsUM, supra note 12, at OV[1] ("To obtain a patent grant, an inventor must file ... an application with the United States Patent and Trademark Office ('PTO'). The application must include a specification describing and precisely claiming the invention. The PTO ... determines whether the applicant's invention complies with the legal requirements of patentability: novelty, utility, nonobviousness, enabling disclosure, and clear claiming."). Through this combination of substantive prerequisites (i.e., the creation of a genuinely novel invention) and the mandatory disclosure of the invention's particulars, society obtains more than merely trendy new products or clever applications of existing products or processes, but an ever expanding body of utilitarian knowledge, information, and skill. See generally Smith \& Mann, supra note 12, at 256-58, 263; Julie E. Cohen \& Mark A. Lemley, Patent Scope and Innovation in the Software Industry, 89 CAL. L. Rev. 1 (2001); Margo A. Bagley, Academic Discourse and Proprietary Rights: Putting Patents in Their Proper Place, 47 B.C. L. Rev. 217 (2006); Shubha Ghosh \& Jay Kesan, What Do Patents Purchase? In Search of Optimal Ignorance in the Patent Office, 40 Hous. L. REv. 1219, 1244-45 (2004). This results in both revolutionary inventions and significant advances in the learning in various fields of scientific and utilitarian endeavor. See generally Margo A. Bagley, Patently Unconstitutional: The Geographical Limitation on Prior Art in a Small World, 87 MinN. L. Rev. 679, 692-95 (2003); Kristen Jakobsen Osenga, Rethinking Reexamination Reform: Is It Time for Corrective Surgery, or Is It Time to Amputate?, 14 Fordham Intell. Prop. Media \& Ent. L.J. 217 (2003); Paul Michel, Judicial Constellations: Guiding Principles as Navigational Aids, 54 CASE W. Res. L. ReV. 757 (2004).

14. 35 U.S.C. § 271(a) (2006) ("Except as otherwise provided in this title, whoever without authority makes, uses, offers to sell, or sells any patented invention, within the United States or imports into the United States any patented invention during the term of the patent therefor, infringes the patent."); see 5 CHIsum, supra note $12, \S 16.02$ [1], at 16-9 ("Basically, a patent grants to the patentee and his assigns the right to exclude others from making, using, and selling the invention. It does not grant the affirmative right to make, use or sell. For example, a person may own a valid patent but be restrained from making, using or selling the invention by a valid 'blocking' patent of another or by the operation of state or federal laws." (footnotes omitted)); Roger E. Schechter \& John R. Thomas, Principles of Patent Law 4 (2004); Simone A. Rose \& Debra R. Jessup, Whose Rules Rule? Resolving Ethical Conflicts During the Simultaneous Representation of Clients in Patent Prosecution, 44 IDEA 283, 290-91 (2004). 
holder may reap commercial gain from her work, either by personally exploiting her lawful monopoly or by licensing her exclusive rights to others. ${ }^{15}$

Whereas significant utilitarian achievement and advancement is the goal of the patent law, the social utility objectives of the copyright law are quite different. ${ }^{16}$ To begin with, unlike patent protection, copyright protection is not dependent upon the demonstration of any "revolutionary advance." ${ }^{17}$ Indeed, the copyright originality threshold mandates only the independent creation of artistic expression which reflects at least "a spark of creativity." 18 From the

15. See 35 U.S.C. $\S \S 154,271$ (2006); 5 Chisum, supra note 12, § 16.02, at 16-7 (““[A] patent confers an exclusive right upon the patentee, limited in those terms. He may prevent any one from making, selling or using a structure embodying the invention, but the monopoly goes no further than that." (quoting Van Kannell Revolving Door Co. v. Revolving Door \& Fixture Co., 293 F. 261, 262 (S.D.N.Y. 1920)).

16. Indeed, Professor Nimmer, in his capacity as a CONTU Commissioner, cautioned that providing treatment for software programs identical to that provided for traditional artistic works could present a plethora of social utility and doctrinal challenges and force copyright law to "the breaking point," transforming it to a general misappropriations law. See CONTU Final RePORT, supra note 2, at 53-55; see also 17 U.S.C. $§ 102(\mathrm{~b})$.

17. See Smith \& Mann, supra note 12, at 257 ("The patent examination process is designed to ensure that legal protection will extend only to technologies that are truly novel, useful, and non-obvious. Whether in terms of the European requirement of an 'inventive step,' or in terms of a non-obvious advance over existing technology, issued patents must embody something truly new and innovative. Copyright law, by contrast, promotes creativity by protecting any original work of authorship fixed in a tangible medium of expression; any work that does not copy the expressive content of another protected work will be entitled to copyright protection regardless of whether it is new, useful, or constitutes an advance over pre-existing works. This substantially lower threshold of protection for copyrights as compared to patents suggests that patent protection may provide a greater incentive than copyright for software developers to focus their efforts on achieving truly innovative advances in technology." (footnotes omitted)); 1 Nimmer \& Nimmer, supra note $2, \S 2.01[\mathrm{~B}]$, at 2-13 to -16 ("Within these (in the words of Justice Holmes) 'narrowest and most obvious limits,' there is invoked at least a minimal requirement of creativity over and above the requirement of independent effort. Moreover, the mere fact of success in the marketplace cannot vouchsafe the necessary quantum of originality. It is of only semantic significance whether originality is defined as embodying such creativity or whether such creativity is regarded as a necessary adjunct to originality. As one court puts it: 'Originality merely requires independent creation by the author and just a scintilla of creativity.' However, a greater clarity of expression is perhaps achieved by regarding originality and creativity as separate elements. As with all words, care must be exercised to ascertain the precise meaning of the terms employed, here 'originality' and 'creativity.' We have just seen that the former does not connote novelty. By the same token, the latter does not mean an 'inventive leap' or 'new idea' in the sense of never having been conceived before. Instead, it refers to matter bearing a spark of distinctiveness in copyrightable expression. Illustrative of the requirement of minimal creativity are those cases that deny copyright protection to fragmentary words or phrases, noncreative variations of musical compositions, numbers generated sequentially or randomly, and to forms of expression dictated solely by functional considerations." (footnotes omitted)); see also Jisuk Woo, Genius With Minimal Originality?: The Continuity and Transformation of the "Authorship" Construct in Copyright Case Law Regarding Computer Software, 15 ALB. L.J. SCI. \& Tech. 109 (2004); Arjun Gupta, Comment, "I'll Be Your Mirror"-Contemporary Art and the Role of Style in Copyright Infringement Analysis, 31 U. DAYton L. REV. 45 (2005).

18. See Gupta, supra note 17; see also ; Bleistein v. Donaldson Lithographing Co., 188 U.S. 239 
standpoint of copyright law, the stimulation of individual expression, interpretation, and the corollary public enlightenment is its own reward. ${ }^{19}$ Thus, there is no requirement that any substantive component within a protected work be novel. Nor, for that matter, is it necessary that any didactic information or processes set forth therein prove accurate or effective; the fact that the description of a process is copyrighted provides no assurance that the process actually works. In short, in direct contrast to patent law, copyright law in no way undertakes to assess the utilitarian merit of works protected thereunder, and consequently, in this regard, copyright law is not immediately compatible with the functional nature and concomitant benefits presented by computer software programs. ${ }^{20}$

(1903); 1 Nimmer \& Nimmer, supra note 2, § 2.01[B], at 2-17 (“[E]ven a short phrase may command copyright protection if it exhibits sufficient creativity. Thus Judge Jerome Frank in Heim v. Universal Pictures Co., suggested that copyright protection would be accorded such lines as 'Euclid alone has looked on Beauty bare' and 'Twas brillig and the slithy toves.' It appears, then, that there is a reciprocal relationship between creativity and independent effort. The smaller the effort (e.g., two words), the greater must be the degree of creativity in order to claim copyright protection." (footnotes omitted) (quoting Heim v. Universal Pictures Co., 154 F.2d 480, 487 n.8 (2d Cir. 1946))).

19. See Sony Corp. of Am. v. Universal City Studios, Inc., 464 U.S. 417, 431-32 (1984) ("Creative work is to be encouraged and rewarded, but private motivation must ultimately serve the cause of promoting broad public availability of literature, music, and the other arts. The immediate effect of our copyright law is to secure a fair return for an 'author's' creative labor. But the ultimate aim is, by this incentive, to stimulate artistic creativity for the general public good." (quoting Twentieth Century Music Corp. v. Aiken, 422 U.S. 151, 156 (1975)); 1 Nimmer \& Nimmer, supra note 2, § 1.03[A], at 1-88 n.2 (“[I]t is clear that the real purpose of the copyright scheme is to encourage works of the intellect, and that this purpose is to be achieved by the reliance on the economic incentives granted to authors and inventors by the copyright scheme." (quoting Universal City Studios, Inc. v. Sony Corp. of Am., 659 F.3d 963, 965 (9th Cir. 1981), rev'd, 464 U.S. 417 (1984))).

20. These challenges notwithstanding, CONTU concluded that copyright protection should be extended to software programs. See CONTU FinAL RePort, supra note 2, at 42-43 ("It has been suggested by Vice-Chairman Nimmer in his separate opinion that programs be copyrighted only when their use leads to copyrighted output. If this approach were adopted, it would make a program for text editing or the production of graphics copyrightable. It would, however, exclude a program which might be used to assist traffic flow in rush hours or to monitor the vital signs of patients under intensive care. This distinction is not consistent with the design of the Act of 1976, which was clearly to protect all works of authorship from the moment of their fixation in any tangible medium of expression. Further, it does not square with copyright practice past and present which recognizes copyright protection for a work of authorship regardless of the uses to which it may be put. The copyright status of the written rules for a game or a system for the operation of a machine is unaffected by the fact that those rules direct the actions of those who play the game or carry out the process. Nor has copyright been denied to works simply because of their utilitarian aspects. It follows, therefore, that there should likewise be no distinction made between programs which are used in the production of further copyrighted works and those which are not. Should such a distinction be made, the likelihood is that entrepreneurs would simply require that programs produce a written and, by that token, an unquestionably copyrightable version of their output in order to obtain copyright in the programs themselves. Although the distinction tries to achieve the separation of idea from form of expression, that objective is better achieved through the courts exercising their judgment in 
In addition to the foregoing intrinsic incompatibilities, there is the further problem of integrating software programs into the copyright author incentive system of exclusive rights. As discussed above, unlike patent protection, which reserves to the patent holder the "negative exclusive right" to make, use, or sell her invention, copyright law reserves to the copyright holder only certain enumerated uses for her work. ${ }^{21}$ Devised with aesthetic expression in mind, copyright exclusive rights are intended to provide property right protections and incentives for creative authors to produce artistic works while at the same time assuring the public's right to otherwise use and enjoy (i.e., read, sing, etc.) copyrighted works, who may thereby find the inspiration to create new works. ${ }^{22}$

The inherently digital nature of software programs, however, makes it difficult to apply and enforce exclusive rights in a manner consistent with the overarching goals of copyright law. Whereas an individual can usually read a book or sing a song without violating the copyright holder's exclusive rights, in order to use a software program, it is necessary to upload and access it through a computer. ${ }^{23}$ Such activity constitutes copying, at least in the

particular cases." (footnote omitted)).

21. See, e.g., 2 Nimmer \& Nimmer, supra note 2, § 8.01[A], at 8-15; Alan L. Durham, Comment, Consumer Modification of Copyrighted Works, 81 IND. L.J. 851, 879 (2006) ("One does not need the permission of the copyright holder to read a novel, study a painting, or look up information in a directory. In addition, the performance and display rights . . . are limited to public performances and displays. . . . By implication, consumers can, without the permission of the copyright holder, perform or display a copyrighted work in the privacy of their homes. Consumers can sing in the shower, or enjoy a movie with family and friends, without owing royalties."); see also Meridian Project Sys., Inc. v. Hardin Constr. Co., 426 F. Supp. 2d at 1109 ("Reverse engineering is not within the scope of the exclusive rights of copyright.").

22. See Eldred v. Ashcroft, 537 U.S. 186, 212 n.18 (2003); Sony Corp. of Am. v. Universal City Studios, Inc., 464 U.S. 417, 429 (1984); Twentieth Century Music Corp. v. Aiken, 422 U.S. 151, 156 (1975); 1 Nimmer \& NimmeR, supra note 2, § 1.03[A], at 1-88 n.2 ("[The exclusive rights are] intended to motivate the creative activity of authors and inventors by the provision of special reward, and to allow the public access to the products of their genius after the limited period of exclusive control has expired." (quoting Sony Corp. of Am., 464 U.S. at 429)); 2 GoLD STEIN, supra note 8, § 7.0.1, at 7:5 ("Section 106(4) thus aligns the interest of the individual copyright owner with the public good by ensuring that the copyrighted work will be put to its more highly valued use. The Copyright Act does not, of course, require a copyright owner to respond to any proposal with such economic rationality. A copyright owner may reject a proposed license for any reason or for no reason at all. But the Copyright Act assumes that, in most situations, the copyright owner will license the higher valued use."); see also Lexmark Int'l, Inc. v. Static Control Components, Inc., 387 F.3d 522 (6th Cir. 2004); Apple Computer, Inc. v. Formula Int'l Inc., 594 F. Supp. 617 (C.D. Cal. 1984); Sony Computer Entm’t, Inc. v. Connectix Corp., 203 F.3d 596 (9th Cir. 2000), cert. denied, 531 U.S. 871 (2000).

23. See CONTU Final RePORT, supra note 2, at 24 ("[T] he placement of a work into a computer is the preparation of a copy....”); Apple Computer, Inc., 594 F. Supp. at 621 (“[The CONTU Final Report] pointed out that computer programs written on paper cannot be used at all in a computer without being 
broadest sense of the term. ${ }^{24}$ Moreover, in order to use a software program on
a specific computer system, it is often necessary to make modifications and
adjustments to the program. ${ }^{25}$ Making changes to a copyrighted work,

trans lated (i.e., 'copied') into machine-readable form, and programs on diskettes cannot . . be used without first being loaded (i.e.[,] 'copied') into some memory device in the computer.").

24. See Jessica Litman, Revising Copyright Law for the Information Age, 75 OR. L. Rev. 19, 19-21 (1996) ("Our current copyright law is based on a model devised for print media, and expanded with some difficulty to embrace a world that includes live, filmed and taped performances, broadcast media, and, most recently, digital media. That much is uncontroversial. The suitability of that model for new media is much more controversial. ... [S]ince any use of a computer to view, read, reread, hear or otherwise experience a work in digital form requires reproducing that work in a computer's memory, and since the copyright statute gives the copyright holder exclusive control over reproductions, everybody needs to have either a statutory privilege or the copyright holder's permission to view, read, reread, hear or otherwise experience a digital work . . .." (footnotes omitted)); Ivan K. Fong, Law and New Technology: The Virtues of Muddling Through the Digital Dilemma: Intellectual Property in the Information Age, 19 Yale L. \& PoL'y REv. 443, 445, 447 (2001) (book review) (“'Many of the intellectual property rules and practices that evolved in the world of physical artifacts do not work well in the digital environment'... [U]nlike access to traditional media (reading a book, watching a movie, or listening to a CD), access to digital works inevitably requires the making of a copy, and that, unlike copying traditional works, copying digital works is easy, inexpensive, and produces perfect copies. Add to that the fact that computer networks now make global distribution of that information inexpensive and nearly instantaneous, and one can easily see how existing copyright law, which might have prohibited (or at least tolerated) the individual copying contemplated in the analog world of traditional media, might be ill-suited to deal with the sort of mass copying rendered simple and commonplace on the Internet." (footnote omitted)); 2 Nimmer \& Nimmer, supra note $2, \S 8.08$ [A][1], at 8-128.2 ("Does the unauthorized input of [a copyrighted] work into a computer constitute an infringement of the reproduction right? ... [T]he current Act ... defin[es] 'copy' to include any material objects (other than a phonorecord) whereby a [protected] work may be 'perceived, reproduced or otherwise communicated, either directly or with the aid of a machine or device.' ... [T]his expanded definition makes clear that the input of a work into a computer results in the making of a copy, and hence, that such unauthorized input infringes the copyright owner's reproduction right." (footnotes omitted)); see also Apple Computer, Inc., 594 F. Supp. at 622 ("Every general purpose computer apparently contains what is called RAM. This is an acronym for Random Access Memory. RAM can be simply defined as a computer component in which data and computer programs can be temporarily recorded. Thus, the purchaser of a ... diskette [containing software programs] desiring to utilize in his computer all of the programs on the diskette could arrange to copy the ... programs into RAM."); MAI Systems Corp. v. Peak Computer, Inc., 991 F.2d 51 1, 518 (9th Cir. 1993); Sega Enters. Ltd. v. Accolade, Inc., 977 F.2d 1510, 1520 (9th Cir. 1993); Vault Corp. v. Quaid Software Ltd., 847 F. 2d 255, 261 (5th Cir. 1988).

25. See CONTU Final RePORT, supra note 2, at 25 ("Because of a lack of complete standardization among programming languages and hardware in the computer industry, one who rightfully acquires a copy of a program frequently cannot use it without adapting it to that limited extent which will allow its use in the possessor's computer. The copyright law, which grants to copyright proprietors the exclusive right to prepare translations, transformations, and adaptations of their work, should no more prevent such use than it should prevent rightful possessors from loading programs into their computers. Thus, a right to make those changes necessary to enable the use for which it was both sold and purchased should be provided. The conversion of a program from one higher-level language to another to facilitate use would fall within this right, as would the right to add features to the program that were not present at the time of rightful acquisition." (footnote omitted)); see also Sega Enters. Ltd., 977 F.2d at 1520. 
however, can result in the unauthorized creation of a derivative work, which would also constitute a violation of the copyright holder's exclusive rights. ${ }^{26}$

At the same time, the digital format of software programs presents a threat to the property rights and incentive mechanisms that copyright law provides to creators. ${ }^{27}$ Unlike traditional copyrighted works, many of which are still commercially distributed in non-digital formats, ${ }^{28}$ the necessarily

26. 17 U.S.C. $§ 101$ (2006) (“A 'derivative work' is a work based upon one or more preexisting works, such as a translation, musical arrangement, dramatization, fictionalization, motion picture version, sound recording, art reproduction, abridgment, condensation, or any other form in which a work may be recast, transformed, or adapted. A work consisting of editorial revisions, ann otations, elaborations, or other modifications which, as a whole, represent an original work of authorship, is a 'derivative work."'). See generally 1 Nimmer \& Nimmer, supra note 2, § 3.03, at 3-11 to -22.7; 1 Paul Goldstein, Copyright: Principles, Law and Practice $\S 5.3 .1$, at 574-76 (1989); Emilio B. Nicholas, Note, Why the Ninth Circuit Added Too Much to Subtract Add-On Software from the Scope of Derivative Works Under 17 U.S.C. 106(2): A Textual Argument, 2004 Syracuse Sci. \& Tech. L. Rep. 1 (2004).

27. See, e.g., Adobe Sys., Inc. v. Stargate Software, Inc., 216 F. Supp. 2d 1051, 1059 (N.D. Cal. 2002) ("Software fundamentally differs from more traditional forms of medium, such as print or photographic materials, in that software can be both, more readily and easily copied on a mass scale in an extraordinarily short amount of time and relatively inexpensively. One of the primary advantages of software, its ability to record, concentrate and convey information with unprecedented ease and speed, makes it extraordinarily vulnerable to illegal copying and piracy. [Consequently,] it is important to acknowledge these special characteristics of the software industry and provide enhanced copyright protection for its inventors and developers."). See generally Lori A. Morea, The Future of Music in a Digital Age: The Ongoing Conflict Between Copyright Law and Peer-to-Peer Technology, 28 CAMPB ELL L. REV. 195 (2006)(“In today's technology-driven environment, information is constantly at our fingertips. Although computer-based technology simplifies many everyday activities, the technology also unfortunately makes it convenient and simple to violate United States copyright laws. Each and every day, substantial numbers of people, specifically college students, download copyright-protected music over peer-to-peer networks, which violates the rights of artists who legally maintain control over the reproduction and distribution of their creations. Copyright infringement hurts artists financially, and it also discourages further creativity and innovation. On the other hand, consumers contend that they have been pushed towards illegal behavior because it is convenient and the cost of buying authorized copies of CDs is unreasonably high and continues to increase.").

28. For example, now that music is commercially distributed almost exclusively in digital formats music copyright holders, unlike the authors of printed works, face the same challenges as software developers. See Ryan Bates, Comment, Communication Breakdown: The Recording Industry's Pursuit of the Individual Music User, a Comparison of U.S. and E.U. Copyright Protections for Internet Music File Sharing, 25 Nw. J. InT'L L. \& Bus. 229 (2004); Matthew C. Mousley, Note, Peer-To-Peer Combat: The Entertainment Industry's Arsenal In It's War On Digital Piracy, 48 VILL. L. REv. 667 (2003); Joshua S. Bauchner, Globalization and Democratization: The Reclaiming of Copyright, 4 TuL. J. TECH. \& InTELL. Prop. 93 (2002); David A. Hepler, Dropping Slugs in the Celestial Jukebox: Congressional Enabling of Digital Music Piracy Short-Changes Copyright Holders, 37 SAn Diego L. Rev. 1165 (2000); June Chung, The Digital Performance Right in Sound Recordings Act and its Failure to Address the Issue of Digital Music's New Form of Distribution, 39 ARIZ. L. ReV. 1361 (1997); Edward T. Saadi, Sound Recordings Need Sound Protection, 5 Tex. Intell. Prop. L.J. 333 (1997); Lateef Mtima et al., Songs of Love and Arias of Fear: Separating the Napster Hip-Hop from the Hype, LEGAL TimEs, Oct. 16, 2000, at 42; see also Durham, supra note 21, at 852 ("For a fee ... consumers who have purchased a DVD copy of a copyrighted 
digital format of software programs renders them especially vulnerable to mass duplication and distribution to multiple recipients without detection. ${ }^{29}$ In addition, software programs are amenable to unauthorized alteration. ${ }^{30}$ In sum, the digital format of software programs makes it difficult to enforce even the most basic of the copyright holder's exclusive rights: the rights to reproduce, distribute, and/or prepare derivative versions of her work. ${ }^{31}$

motion picture [can obtain and use software] to experience that motion picture without profanity, vulgarity, or violence. Critics describe this practice as an assault on the director's artistic integrity and a violation of copyright. Consumers might defend it as a prerogative of ownership, an exercise of their individuality, or a defense of 'family values.' As more works of authorship are delivered through digital media, the temptation can only grow to improve, rearrange, customize, and remix." (footnotes omitted)).

29. See, e.g., Adobe Sys., Inc., 216 F. Supp. $2 \mathrm{~d}$ at 1059; Niva Elkin-Koren, Cyberlaw and Social Change: A Democratic Approach to Copyright Law in Cyberspace, 14 CARdozo ARTs \& ENT. L.J. 215, 254-55 (1996) ("Digitization allows users to easily retransmit materials. Users may use scanners to digitize photos or texts that are published in a traditional form. A digitized copy that was delivered through the network may be downloaded by the user and retransmitted. Retransmission through digitized versions is both easy and inexpensive. Everything digitized may be reproduced in seconds and at low cost. Selfpublishing is also available through network communication.... Cyberspace integrates the generation and distribution of information. Digital networks provide direct communication between authors and potential readers .... Consequently, everyone with access to a computer network may become a publisher. Network distribution creates a continuum that goes from personal writing on one hand, to publication on the other, with many degrees of connectivity and access permissions in between." (footnotes omitted)); Wendy M. Pollack, Note, Tuning in: The Future of Copyright Protection for Online Music in the Digital Millennium, 68 FoRDHAM L. REV. 2445 (2000)("Digitization of copyrighted materials permits instantaneous, simplified copying methods that produce nearly perfect copies of originals. These copies can be digitally delivered to thousands of Internet users. Decentralization and anonymity in cyberspace have allowed for the widespread dissemination of copyrighted materials without permission from their owners." (footnotes omitted)). Although technological advances (and accompanying changes in the copyright law, such as the Digital Millennium Copyright Act) have made unauthorized modification of software more difficult to undertake, not only is it still possible, but, as discussed infra, the law is still unclear as to the extent that unauthorized modification is permissible. See generally Mtima, supra note 10, at 13; Andrew BeckermanRodau, Ethical Risks From The Use of Technology, 31 Rutgers Computer \& TeCh. L.J. 1, 11, 28-29, 33-34 (2004). Technical capabilities aside, copyright holders and software users alike would benefit from concrete delineation of their respective rights.

30. See, e.g., Durham, supra note 21, at 884 ("The most malleable works of authorships are those that exist in the form of data. Modifying a law review article printed on paper is a relatively difficult task, and the results, whether achieved by cutting and pasting, or crossing out and interlineating, are likely to be unattractive. Modifying the same article in electronic form is easy. One can delete the author's concluding paragraph and substitute one's own, or one can select the entire document and replace Times New Roman font with Albertus Extra Bold font. With little effort, the result can look pleasing as the original.").

31. Id. Although advances in digital rights management and encryption technology have made unauthorized modification of proprietary software more difficult to undertake, such technology provides neither an impenetrable barrier of protection nor an answer to the social policy question as to how much public modification of protected programs should be permitted. See Dan L. Burk, Market Regulation and Innovation; Legal and Technical Standards in Digital Rights Management Technology, 74 Fordham L. REV. 537, 546-51 (2005); see also Lemley \& O’Brien, supra note 7, at 273-74 (“'[T]wo very popular topics of discussion ... have been encryption technology and the undesirability of using patent and copyright law 
These challenges notwithstanding, Congress nonetheless determined that copyright protection would be the most appropriate form of intellectual property protection for computer software programs. ${ }^{32}$ In order to address some of the unique issues presented by software programs as copyrightable works, however, Congress has from time to time amended the copyright law in an effort to ensure that the social utility goals underlying the extension of copyright protection to such works are fulfilled.

For example, in 1998, Congress enacted the Digital Millennium Copyright Act (DMCA), purportedly to bring copyright law into the digital age. ${ }^{33}$ Although often criticized as a patchwork of lobbyist boons,${ }^{34}$ the

to cover software and digital works. ... We argue that while cryptography is extremely useful in establishing security barriers to unauthorized access, it is not a new paradigm destined to supplant intellectual property law. Rather, it simply establishes more effective barriers to reverse engineering (decryption) than does embedding a program in object code. Even assuming that it provided perfect security, which it does not, encryption merely shifts the focus of trade secret misappropriation to the end user. Software components must be decrypted to be valuable to purchasers and end users of an integrated software system. While encryption better protects against unauthorized access to the component, it can not prevent unauthorized use or disclosure of the encrypted ideas by those who have legitimately acquired and decrypted them."). As discussed in Part IV infra, non-competitive reuse of protected programs should not be unduly prohibited by the copyright law.

32. See CONTU Final Report, supra note 2, at 21; see also Control Data Sys., Inc. v. Infoware, Inc., 903 F. Supp. 1316, 1325 (D. Minn. 1995) ("In the field of computer technology, nearly all products have a limited life span. The arrival of new programs and hardware will someday make every program obsolete. Copyright law seeks to protect the original expres sions contained in computer soft ware while they are not yet obsolete and bars infringers from unfairly hastening the end of their useful life.").

33. See Digital Millennium Copyright Act, Pub. L. No. 105-304, 112 Stat. 2860 (1998) (codified as amended in scattered sections of 17 U.S.C.).

34. See, e.g., Okediji, supra note 10, at 109-11 ("Congress has ... deliberately expanded owners' rights through recent legislation, most notably the Digital Millennium Copyright Act (DMCA) and the Copyright Term Extension Act (CTEA).... [These] legislative enactments-both the process by which they came to fruition as well as their substantive provisions-give reason to pause over Congress' commitment to the public interest, or at the very least, its understanding of the implications of the expansion of the copyright law." (footnotes omitted)); David W. Opderbeck, Peer-to-Peer Networks, Technological Evolution, and Intellectual Property Reverse Private Attorney General Litigation, 20 BeRKeley TeCh. L.J. 1685, 1689 (2005) ("The reverse private attorney general action is likely to gain increasing prominence in the intellectual property arena. All content industries are concerned about what they consider digital piracy over P2P and other online networks. The content industries gained a powerful weapon against such 'piracy' with the Digital Millennium Copyright Act, which supplements the already formidable Copyright Act with broad subpoena powers and prohibitions on circumvention of encryption measures and trafficking in circumvention technology."); Morea, supra note 27, at 201 ("In 1998, the U.S. Congress enacted the Digital Millennium Copyright Act (DMCA) to prohibit the circumvention of tools that protect copyrighted works from being reproduced illegally. The DMCA included specific 'expedited subpoena provisions' that could be used to quickly obtain the private information of Internet users." (footnote omitted)); Burk, supra note 31, at 557 ("In the United States, a legal deterrent of this kind has been enacted in the form of the Digital Millennium Copyright Act ('DMCA'), which prohibits circumvention of technical protection measures, and trafficking in technology that would facilitate such 
DMCA is a potpourri of provisions which preserve (or enhance) a variety of copyright constituent interests in digital works and the digital use of traditional works. On behalf of copyright holders, the DMCA provides "anticircumvention" provisions which make unlawful the unauthorized decryption of copyright protection mechanisms. ${ }^{35}$ On behalf of software users, Congress included provisions in the DMCA overruling MAI Systems Corp. v. Peak Computer, Inc. ${ }^{36}$ which held that non-volitional RAM copying of software programs, which occurs when maintenance providers turn on their customers' computers in order to provide service, constitutes unauthorized copying in violation of the copyright holder's reproduction right. ${ }^{37}$ Until Congress overruled MAI Systems, computer users and maintenance providers could not address routine maintenance needs without risking copyright infringement litigation by the owners of all protected programs resident on the subject computers. ${ }^{38}$

While Congress has undertaken various other efforts to reconcile the competing rights and interests of copyright holders and software users, ${ }^{39}$ the primordial software-user versus copyright-holder social balancing amendment is 17 U.S.C. $\S 117 .^{40}$ As discussed in the next section, section 117 functions

circumvention. This statute effectively provides content owners a new right of technological access, seemingly independent of any intellectual property right." (footnote omitted)); Annie R. Lin, Note, Who Owns the Cow When We Give Away the Milk for Free? Fair Use and the Protection of Web-Posted Materials, 3 Buff. Intell. Prop. L.J. 46, 58 (2005) ("Congress introduced the Digital Millennium Copyright Act (DMCA) to address the liability issues that arise for software owners and ISPs.").

35. See 17 U.S.C. $\$ 1201$ (2006). See generally Morea, supra note 27, at 217 ("The final and most recent expansion of criminal copyright penalties occurred in 1998, with the enactment of the Digital Millennium Copyright Act (DMCA). The DMCA, like the other legislation discussed, was a reaction by Congress to the growth and advancement of technology. The statute disallows the circumvention of technological tools that have been implemented to protect copyrighted works from being reproduced illegally, and also bans trafficking in prohibited tools that are capable of circumventing technology." (footnotes omitted)).

36. 991 F.2d 511 (9th Cir. 1993).

37. Id. at 518; see also Rand McNally \& Co. v. Fleet Mgmt. Sys., Inc., No. 80-C4499, 1984 U.S. Dist. LEXIS $23142, * 4-5$ (N.D. Ill. Oct. 1, 1984) (holding that inputting copyrighted mileage data from highway maps into computer constitutes copying under 17 U.S.C. § 117).

38. See $\$ 117(c)$. See generally Lateef Mtima, The Hunt for a Clear October: Manufacturers, ISOS, and the Fonar Decision, Andre ws Intell. Prop. Litig. Rep., Mar. 12, 1997, at 20; Ronald Katz \& Lateef Mtima, Uncertainty Reigns in Software Cases, The NAT'L L.J., May 12, 1997, at C46 col. 2.

39. See, e.g., Okediji, supra note 10, at 109 n.5 ("Congress created ... (CONTU) to provide the President and Congress with recommendations concerning those changes necessary in copyright law or procedure needed both to assure public access to copyrighted works used in conjunction with computer and machine duplication systems and to respect the rights of owners of copyrights in such works, while considering the concerns of the general public and the consumer." (quoting CONTU FINAL REPORT, supra note 2, at 1)).

40. See, e.g., Peter S. Menell, Can Our Conception of Copyright law Survive the Internet Age?: 
as one of the chief mechanisms through which the public interest in software programs is balanced against the copyright holders' property rights in such programs. ${ }^{41}$ Section 117 is also critical to the proper interposition of software programs into the copyright exclusive rights framework. Accordingly, properly construed as a "constituent neutral" balancing mechanism, section 117 is fundamental to the harmonization of the interests of copyright holders and the software-using public.

Envisioning Copyright Law's Digital Future, 46 N.Y.L. Sch. L. Rev. 63, 76 (2002) ("Faced with the difficult challenge of fitting computer and other new information technologies under the existing umbrella of intellectual property protection, Congress in 1974 established the National Commission on New Technological Uses of Copyrighted Works (CONTU), to study theimplications of the new technologies and recommend revisions to the federal intellectual property laws. After conducting hearings and receiving expert reports, a majority of the panel of copyright authorities and interest group representatives concluded that 'computer programs, to the extent that they embody an author's original creation, are proper subject matter of copyright.' CONTU was clear, however, that the fundamental limitation reflected in the idea/expression dichotomy that copyright law cannot protect 'any idea, procedure, process, system, method of operation, concept, principle, or discovery' should apply with equal force with regard to computer programs. Congress implemented CONTU's recommendations in 1980 by adding a definition of 'computer program to 101 of the Copyright Act and amending 117 of the Act to authorize the owner of a copy of a computer program to make another copy or adaptation of the program for the purpose of running the program on a computer."' (footnotes omitted)).

41. See Wall Data Inc. v. L.A. County Sheriff”s Dep’t, 447 F.3d 769, 784 (9th Cir. 2006) (“[Section 117 's] essential step defense attempts to strike a balance between the interests of software users and software developers .... The 'essential step' defense ... ensures that a software user does not infringe when the user 'copies' the software from the computer's permanent storage ... on to its active memory ...." (citation omitted)); CONTU FinAL REPORT, supra note 2, at 25 ("These rights would necessarily be more private in nature than the right to load a program by copying it and could only be exercised so long as they did not harm the interests of the copyright proprietor.”); 2 GOLDSTEIN, supra note $8, \S 7.2 .1 .4$, at $7: 39$ to $: 40$ ("Congress struck a balance between the interests of program users and program producers in the Computer Software Copyright Act of 1980 by adopting, virtually verbatim, the recommendations of the National Commission on New Technological Uses of Copyrighted Works. Section 117, as amended by the Computer Software Copyright Act, provides that it is not an infringement for the owner of a copy of a copyrighted computer program to make, or to authorize the making of, another copy of the program to make, if the copy is created as an 'essential step in the utilization of the computer program' in connection with the computer, and 'in no other manner,' or if the copy is made 'for archival purposes only and . . a all archival copies are destroyed in the event that continued possession of the computer program should cease to be rightful.' Section 117 also carves out an exemption from section 106(2)'s right to prepare derivative works in order to enable necessary adaptations of computer programs, and modifies the distribution right as applied to computer programs put to these uses." (footnotes omitted)). 


\section{Doing the Commission's Work: Implementing the Section 117 User Adaptation Privilege}

Section 117 is one of the principal amendments to the copyright law promulgated with the unique properties of software programs specifically in mind. ${ }^{42}$ In determining the most appropriate form of intellectual property protection for software programs, CONTU concluded that while copyright protection would spur development in the field, the innately functional nature and digital format of software programs would require some special accommodations for the copyright regime. ${ }^{43}$ Congress addressed certain of CONTU's concerns by adopting section 117, which provides as follows:

(a) Notwithstanding the provisions of section 106, it is not an infringement for the owner of a copy of a computer program to make or authorize the making of another copy or adaptation of that computer program provided:

(1) that such a new copy or adaptation is created as an essential step in the utilization of the computer program in conjunction with a machine and that it is used in no other manner, or

(2) that such new copy or adaptation is for archival purposes only and that all archival copies are destroyed in the event that continued possession of the computer program should cease to be rightful.

(b) Any exact copies prepared in accordance with the provisions of this section may be leased, sold, or otherwise transferred, along with the copy from which such copies were prepared, only as part of the lease, sale, or other transfer of rights in the program. Adaptations so prepared may be transferred only with the authorization of the copyright owner. $^{44}$

42. See, e.g., Digital Millennium Copyright Act, Pub. L. No. 105-304, 112 Stat. 2860 (1998) (codified in scattered sections of 17 U.S.C.).

43. See Vault Corp. v. Quaid Software Ltd., 847 F.2d 255, 259 (5th Cir. 1988) ("CONTU . . recognized that ' $[\mathrm{t}] \mathrm{he}$ cost of developing computer programs is far greater than the cost of their duplication,' . . . and concluded that 'some form of protection is necessary to encourage the creation and broad distribution of computer programs in a competitive market." (quoting CONTU FINAL REPORT, supra note 2, at 20-21)); CONTU Final Report, supra note 2, at 25 ("Because of a lack of complete standardization among programming languages and hardware in the computer industry, one who rightfully acquires a copy of a program frequently cannot use it without adapting it to that limited extent which will allow its use in the possessor's computer. ... Thus, a right to make those changes necessary to enable the use for which it was both sold and purchased should be provided.”).

44. 17 U.S.C. $\S \S 117(a)-(b)(2006)$. 
Pursuant to section 117 , the user ${ }^{45}$ of a software program has the right to make input and access copies, and to create archival copies of the program, without permission from the copyright holder. Users are also permitted to make "adaptations" of protected programs as necessary for their proper use. These provisions prevent copyright holders from deploying their exclusive rights so as to hamper the legitimate use of their programs in the hands of the public, thereby assuring that the benefits of copyright protection are not misapplied. ${ }^{46}$

Section 117's relationship to section 106 and the copyright holder's exclusive rights is both straightforward and complex. Section 117 does not deprive the copyright holder of any of her exclusive rights but rather acknowledges that the unique nature of software programs necessitates some limited incursion upon those rights. Accordingly, section 117 bestows certain "privileges" ${ }^{47}$ upon legitimate users of software programs to tread, however

45. Although most commercial software transactions today are structured as licenses, section 117's grant of privileges to "owners" of copies of protected programs has not precluded its application on behalf of software lic ensees, especially consumer users. See, e.g., Mtima, supra note 10, at 13, 15-16. In Krause v. Titleserv, Inc., 402 F.3d 119 (2d Cir. 2005), Judge Leval clarified that under the copyright law, the term "owner" may refer to certain incidents of ownership as opposed to outright title. Id. at 122-24. Although Judge Leval's insightful opinion would seem to resolve satisfactorily the section 117 owner-versus-user conundrum, the courts of some other circuits cling to a contrary view. See, e.g., Wall Data Inc., 447 F.3d at 784-86 (maintaining that licensees are not owners of their copies for purposes of section 117); DSC Commc'ns Corp. v. Pulse Commc'ns, Inc., 170 F.3d 1354, 1361 (Fed. Cir. 1999); MAI Sys. Corp. v. Peak Computer, Inc., 991 F.2d 511, 518 n.5 (9th Cir. 1993); see also Madison River Mgmt. Co. v. Bus. Mgmt. Software Corp., 387 F. Supp. 2d 521, 537-39 \& n.12 (M.D.N.C. 2005) (noting different tests for applying section 117). Consequently, the section 117 owner-versus-licensee issue now reflects a definite split among the leading circuits that interpret and apply the copyright and other intellectual property law-a split that will likely be resolved by the Supreme Court. Until the owner-versus-licensee issue is definitively resolved, however, most of section 117's beneficial provisions are nonetheless available to legitimate software users under the fair use doctrine. See, e.g., Madison River Mgmt. Co., 387 F. Supp. 2d at 537-41. Moreover, private license agreements that preclude licensees from engaging in these privileges likely implicate the federal preemption doctrine. See, e.g., Foresight Res. Corp. v. Pfortmiller, 719 F. Supp. 1006, 1010 (D. Kan. 1989); Mtima, supra note 10, at 13-15. But see Davidson \& Assocs., Inc. v. Internet Gateway, Inc., 334 F. Supp. 2d 1164, 1180 (E.D. Miss. 2004), aff'd, 422 F.3d 630 (8th Cir. 2005) (holding that a software licensee may contractually "waive" her fair use right to reverse engineer copyrighted programs); accord ProCD, Inc. v. Zeidenberg, 86 F.3d 1447, 1454-55 (7th Cir. 1996).

46. See, e.g., 2 Nimmer \& Nimmer, supra note 2, § 8.08[B][1], at 8-133 ("Obviously, creators, lessors, licensors, and vendors of copies of programs intend that they be used by their customers, so that rightful users would but rarely need a legal shield against potential copyright problems. It is easy to imagine, however, a situation in which the copyright owner might desire, for good reason or none at all, to force a lawful owner or possessor of a copy to stop using a particular program. One who rightfully possesses a copy of a program, therefore, should be provided with a legal right to copy it to that extent which will permit its use by that possessor." (quoting CONTU Final RePORT, supra note 2, at 24)); Okediji, supra note 10, at 117 ("Copyright envisions use by members of the public.").

47. See, for example, N.Y. Times Co. v. Tasini, 533 U.S. 483, 496-97 (2001), wherein the Supreme 
lightly, upon the exclusive property rights of copyright holders in order to effectuate a proper balance between the interests of copyright holders and the software-using public. Thus, by virtue of its express reference to permissible copies, ${ }^{48}$ section 117 user privileges indisputably permit a limited encroachment upon the copyright holder's section 106 reproduction right. ${ }^{49}$

The relationship between section 117 user privileges and section the 106 derivative work right, however, is somewhat less clear. ${ }^{50}$ The undefined reference to "adaptation" in section 117, as opposed to "derivative work," creates an ambiguity. While the statutory definition of derivative work $^{51}$ would seem to encompass adaptations, the term "adaptation" is itself susceptible to broad interpretation. ${ }^{52}$ Moreover, the statutory definition of derivative works both distinguishes between differences in adaptations of an original work, such as abridgements versus condensations, but includes them all as examples of forms "in which a work may be recast, transformed, or adapted." ${ }_{33}$ Thus, adaptation within the meaning of section 106 appears synonymous with derivative work. There is nothing in the language of section 117, however, that suggests such an expansive definition of the term.

Another reason to conclude that section 117 adaptations differ in some ways from section 106 derivative works is that the two sections serve

Court distinguished between the exclusive rights of copyright holders and the express "privileges" bestowed upon the public to engage in those rights for specific purposes. Consistent with the Court's articulation in Tasini, the user beneficial provisions of section 117 are most appropriately characterized as copyright privileges. See Jessica Litman, The Public Domain, 39 Emory L.J. 965, 971(1990) ("We describe the exceptions to the exclusive control attending [copyright] ownership as privileges.").

48. The term "copies" is expressly defined by 17 U.S.C. $\S 101$ (2006).

49. See 2 Nimmer \& Nimmer, supra note $2, \S 8.08$ [B][1], at 8-133 ("If the 1980 [CONTU] amendment generally renders unauthorized input of copyrightable subject matter into a computer an infringing act. ... Section 117 also creates an important exemption with respect to one particular form of input: computer programs. Again, ... Congress looked to and followed the recommendations contained in the CONTU Final Report. ... 'Because the placement of a work into a computer is the preparation of a copy, the law should provide that persons in rightful possession of copies of programs to be able to use them freely without fear of exposure to copyright liability."' (footnotes omitted)).

50. See, e.g., 2 Nimmer \& Nimmer, supra note $2, \S 8.08$ [B][2], at 8-142.1 (“A different inquiry arises to the extent that the adaptation so prepared contains more than de minimis aspects, such that it qualifies as a derivative work.").

51. 17 U.S.C. $§ 101$ defines a derivative work as, inter alia, "[A] work based upon one or more preexisting works such as a translation, musical arrangement, dramatization, fictionalization, motion picture version, sound recording, art reproduction, abridgment, condensation or any other form in which a work may be recast, transformed, or adapted."

52. For example, Webster's defines "adaptation" as "something produced by adapting," and provides the terms "modify" and "rework" as synonyms for "adapt." Webster's New Universal UNABRIDGED DictionARY 22 (1996).

53. 17 U.S.C. $\S 101$ (emphasis added). 
different, albeit overlapping, objectives. Arguably, section 117 is concerned with the purpose of changes made to a copyrighted work (does the change facilitate the use of a software program?), whereas section 106 is concerned with the nature of changes made to a copyrighted work (is the change material or substantive, resulting in a derivative work, or merely trivial, resulting in a non-literal copy of the original?). Of course, both trivial and material changes can facilitate the use of a software program, just as changes to facilitate a program's operation may rise to the level of producing a derivative work. Thus, sections 117 and 106 identify categories of revisions that sometimes overlap but offer little guidance as to the treatment of revisions that fit into both categories. In adjudicating the ensuing disputes between copyright holders and software users, courts have struggled to ascertain Congress's intent as to the scope of the adaptation privilege. ${ }^{54}$ Moreover, the significance of the adaptation versus derivative work interface is illuminated when one considers that the only express statutory prerequisite to the qualification of a modified program as an adaptation is that the modification be undertaken "as an essential step in the utilization of the computer program . ..." Th5 Thu, depending on what constitutes such an "essential step," the adaptation privilege could effectively swallow the derivative work right altogether. So long as the user can demonstrate that her modified version of a protected program was prepared in connection with a qualifying use of the original program, any resulting work would be an "adaptation" and therefore largely exempt from the exclusive rights of the copyright holder. ${ }^{56}$

54. See, e.g., Foresight Res. Corp. v. Pfortmiller, 719 F. Supp. 1006, 1009 (D. Kan. 1989) ("There is a dearth both of legislative history and case law interpreting the word 'adaptation,' as used in $\S 117$. As to the legislative history, the House Report accompanying § 117 [merely] states that the law 'embodies the recommendations of the Commission on New Technological Uses of Copyrighted Works . . with respect to clarifying the law of copyright of computer software." (quoting H.R. REP. No. 96-1307, at 23 (1980), as reprinted in 1980 U.S.C.C.A.N. 6460, 6482)); Apple Computer, Inc. v. Formula Int'l, Inc., 594 F. Supp. 617, 620-2 1 (C.D. Cal. 1984) ("No prior case authority has been found construing the [a daptation privilege] portion of Section 117... . No law review article or text has been found which discusses the purpose and scope of Section 117. No regulations have been issued construing or interpreting Section 117. Section 117 was not specifically discussed in either the Senate or House debates on the Copyright Act Amendments of 1980.”)

55. 17 U.S.C. $\S 117(a)(1)$.

56. While the user's privileges in connection with any adaptations she prepares are not unlimited, unauthorized adaptations do compromise the property rights embodied within the derivative work right. See, e.g., 2 NimMER \& NimMER, supra note 2, § 8.08[B][2], at 8-142.1 (“Although any tangible adaptation cannot be transferred without the consent of the owner of the computer program, rights under copyright are distinct from such rights in material objects. The question therefore remains whether, even after destruction of the sole vessel that contained it, copyright ownership over the derivative work remains in the former owner of the computer program." (footnotes omitted)). By the same token, software users have a legitimate 
Delineating the Adaptation Privilege: The "Essential Step Utilization" Prerequisite

As software users became increasingly adept at modifying "off-the-shelf" programs to meet their individual needs, copyright holders insisted that any adaptation privileges bestowed by the copyright statute be narrowly construed. While section 117 does not provide a definition of "adaptation," it does provide that in order for the adaptation privilege to apply, an adaptation must be "created as an essential step in the utilization of the [original] computer program." ${ }^{" 57}$ Consequently, initial litigation disputes over the nature and scope of users' adaptation privileges centered on what kind of use could be considered an "essential step utilization" of a copyrighted software program.

In Foresight Resources Corp. v. Pfortmiller, ${ }^{58}$ the defendant software user made revisions to plaintiff's copyrighted software programs to accommodate certain internal idiosyncrasies pertinent to defendant's asbestos removal business. $^{59}$ There was no dispute that the defendant undertook the modifications solely for its individual use of the program: "[Defendant] uses the [modified program] only in its asbestos removal consulting business. It does not sell computer software and has not attempted to sell either plaintiff's program or defendant's enhancement thereof." 60

The copyright holder commenced infringement litigation, ${ }^{61}$ and in its defense, the defendant user sought to rely upon section 117's adaptation

interest in knowing the scope of their adaptation privileges, in order that they might avoid wasting res ources in the preparation of modifications that might later be prohibited as unauthorized derivative works. Consequently, identifying the line of demarcation between adaptations and derivative works benefits copyright holders and software users alike.

57. 17 U.S.C. $\S 117(\mathrm{a})(1)$.

58. 719 F. Supp. 1006 (D. Kan. 1989).

59. Id. at $1007-08$.

60. Id. at 1008

61. Id. Plaintiff sued both the program user and the consultant who actually undertook the program modifications at the user's behest. The court noted but did not resolve the issue as to whether program users may authorize agents to undertake their section 117 privileges on the users' behalf: "Like what constitutes an 'adaptation,' there is some question as to the nature of the 'authorization' that will suffice to bring an adaptation within the exception carved out by $\S 117$. [S] cholarly commentary suggests that $\S 117$ should not be restricted to prohibit owners from authorizing custom-made enhancements to their copies of copyrighted programs. ..." Id. at 1010 (quoting Richard H. Stern, Section 117 of the Copyright Act: Charter of Software Users' Rights or an Illusory Promise?, 7 W. New Eng. L. Rev. 459, 468 (1985)); see also Llewellyn Gibbons, Entrepreneurial Copyright Fair Use: Let the Independent Contractor Stand in the Shoes of the User, 57 ARK. L. REv. 539 (2004). 
privilege. $^{62}$ The plaintiff challenged the applicability of the privilege, however, on the grounds that the defendant's modifications were undertaken to add functions to the pre-existing program. ${ }^{63}$ Thus, the court was confronted with the task of determining the breadth of the modifications permissible under the adaptation privilege.

If the court ruled in favor of the plaintiff's argument, the "essential step utilization" language in section 117 would be read to restrict software users to undertaking only "interoperability modifications," such as those needed to enable the program to perform its specified function on a particular computer. If the court held for the defendant, the "essential step utilization" provision would encompass program enhancements and thereby enable the user to conform a copyrighted program's performance to her subjective needs. Otherwise, software users could not use programs for the particular purposes for which they acquired them in the first place.

The court agreed with the defendant, concluding that promoting software program and computer system interoperability is but one of section 117's policy objectives. ${ }^{64}$ Enabling the public to exploit the utilitarian capabilities of software programs and, accordingly, improve or customize a program's performance, is yet another:

Construing $\S 117$ to cover the enhancements defendant made to ... plaintiff's program ... would serve two important goals of the copyright laws. On the one hand, allowing sophisticated software users to enhance copies of copyrighted programs they have purchased eliminates the need to choose between either buying the latest version of a program or possibly infringing the program's owner's copyright. At the same time, allowing such enhancements to be used only in-house preserves the market for improvements made by the copyright holder. ${ }^{65}$

Thus, the court concluded that permitting software users the option to "enhance-it-yourself" achieves the balance of interests that Congress intended, provided that individual program enhancements are restricted to private use by the individual adaptor. ${ }^{66}$

62. Foresight Res. Corp., 719 F. Supp. at 1009.

63. Id. at 1010 .

64. Id.

65. Id. at 1010; accord Evolution, Inc. v. Suntrust Bank, 342 F. Supp. 2d 943, 957 (D. Kan. 2004) ("Defendants created [the modified program] from elements of plaintiff's [program] in order to enhance the functionality of plaintiff's software. Defendants did not develop [the modified program] for commercial benefit, but rather to add desired features to plaintiff's software. The court concludes that defendants' creation of [the modified program] was a permissible adaptation of plaintiff's software under Section 117.").

66. Foresight Res. Corp., 719 F. Supp. at 1010. 
In Apple Computer, Inc. v. Formula International, Inc. ${ }^{67}$ the court echoed the Foresight court's emphasis on personal or internal use in construing section $117 .{ }^{68}$ However, in this case, the scope of the "essential step utilization" provision was explored in connection with the creation of an unauthorized copy as opposed to an unauthorized adaptation of a program. ${ }^{69}$ The defendant reproduced Apple's copyrighted software programs onto silicon chips and then sold the chips as parts within its "build your own computer" kit product. ${ }^{70}$ Using one of defendant's kits, a purchaser could assemble a functional Apple computer at a lower cost than purchasing a computer directly from Apple. ${ }^{71}$

When Apple sued for copyright infringement, the defendant relied upon section 117, claiming that "the silicon chips are a new copy [of plaintiff's programs $]$. . . created as an essential step in the utilization of the Apple computer program in conjunction with ... a computer." 72 This time, however, the court did not agree that the defendant's use could be legitimately characterized as an "essential step utilization." "Here, [defendant] is clearly not an owner-user of a computer. [Defendant's] copying of [plaintiff's] programs [on to silicon chips] cannot be construed as 'internal use' by [defendant]." ${ }^{, 73}$ Moreover, the uses to which the copies were put were not "essential step utilizations" of the program:

Every general purpose computer apparently contains what is called RAM. This is an acronym for Random Access Memory. RAM can be simply defined as a computer component in which data and computer programs can be temporarily recorded. . . [Copying plaintiff's copyrighted programs into a computer's RAM] would only be a temporary fixation. It is a property of RAM that when the computer is turned off, the copy of the program recorded in RAM is lost. Thus, in the Court's view, it cannot be persuasively argued that the permanent copying of [plaintiff's] copyrighted programs ...

67. 594 F. Supp. 617 (C.D. Cal. 1984).

68. Id. at 622 .

69. Id. at 618. Although the court's analysis relates to the privilege to make a copy as opposed to an adaptation, the "essential step utilization" prerequisite applies to both copies and adaptations. While the statute does distinguish between the two with respect to the disposition of copies and adaptations, it makes no such distinction in its reference to the "essential step utilization" prerequisite. See 17 U.S.C. $\S 117$ (b) (2006). Thus, the "rules of thumb" for determining whether a use qualifies as an "essential step utilization" should be the same for assessing the legitimacy of both copies and adaptations.

70. Apple Computer Inc., 594 F. Supp. at 619.

71. Id. ("With the chips inserted, the operation of [defendant's computers] becomes functionally equivalent to that of [plaintiff's computers] in that various programs desi gned for [plaintiff's] computer can run on [defendant's] computer.").

72. Id. at 620 (internal marks omitted).

73. Id. at 622 . 
is "an essential step in the utilization" of [plaintiff"s programs]. It is a convenient method, . . . but it is not "essential.","

Further considering the CONTU Final Report and various scholarly commentaries, the court held that the "essential step utilization" requirement mandated that the copy be created by the user for her own personal use in order for it to qualify for the section 117 user privileges:

The Court extracts from these authorities these principles concerning Section 117: 1) Only an owner-user of a computer who rightfully owns a copy of a copyrighted program is authorized to make another copy of that program, and this copying must be necessary for him to be able to use the copyrighted program in his computer; 2) The copy authorized by Section 117 must be made only for the owner-user's internal use and must be destroyed when the original copyrighted work is resold; 3) The copy thus made by the owner-user cannot be made accessible to others. ${ }^{75}$

Vault Corporation v. Quaid Software Ltd. $^{76}$ also involved the unauthorized use of a copyrighted software program in the creation of a subsequent program. ${ }^{77}$ The plaintiff, Vault, was the creator of PROLOK, a

74. Id.; see also Wall Data Inc. v. L.A. County Sheriff's Dep't, 447 F.3d 769, 777-81 (holding that where the copyright holder licensed its software on a "per computer" basis, the licensee's duplication of the program onto multiple internal computers did not constitute an "essential" use, but at best a convenience; at worse, it constituted a scheme to avoid the purchase of add itional "per computer" licenses).

75. Apple Computer, Inc., 594 F. Supp. at 621-22; see also Expediters Int'l of Wash., Inc. v. Direct Line Cargo Mgmt. Servs., Inc., 995 F. Supp. 468 (D.N.J. 1998), wherein defendant instructed plaintiff's software licensees to utilize plaintiff's software to assist defendant's new business, which use was expressly prohibited in plaintiff's license agreements:

[Plaintiff] seeks relief for copyright infringement .... [P]laintiff claims that [defendant] directed and authorized [plaintiff's licensees] to use their copies of the Software to print shipping manifests and bills of lading.

....

Courts examining [the] legislative history have interpreted Section 117 to permit copying for the limited purpose of providing rightful possessors with access to programs for internal use. . . In light of both the legislative history and caselaw concerning Section 117, the Court finds that [plaintiff's licensees'] alleged use of the Software clearly does not fall within the ambit of the exception. The plaintiff alleges that the [licensees] ... generated, transmitted, and used manifests created by the Software to provide billing information to customers [for defendant's benefit]. For the purposes of Section 117, this application transcends mere internal use because it was not necessary for the [licensees] to access the Software in their own computers.

Id. at 473,478 (citations omitted). Because the licensees used the program to perform its intended subjective function, however, and moreover, did not provide the defendant with any actual copies of the subject program (merely the output of the program), the licensees' use of the program to benefit the defendant is perhaps better viewed as a violation of the plaintiff's license agreement, as to which section 117 does not provide an affirmative defense.

76. 847 F.2d 255 (5th Cir. 1988).

77. Id. at 256 
"copy-protect" software program which prevented the creation of fullyfunctional copies of software programs. ${ }^{78}$ Vault's clients used PROLOK in connection with the commercial distribution of their own proprietary software programs in order to prevent their licensees from making and disseminating unauthorized copies of the licensed programs. ${ }^{79}$

The defendant in Vault developed RAMKEY, a program which copied critical components of PROLOK. ${ }^{80}$ Using RAMKEY, a licensee could make fully functional copies of PROLOK-protected proprietary programs by duplicating the necessary PROLOK "fingerprint." ${ }^{\text {" }}$ Consequently, RAMKEY rendered PROLOK useless as a copy-protect device. ${ }^{82}$

Vault brought suit and alleged copyright infringement by the defendant on three grounds. ${ }^{83}$ First, in analyzing PROLOK, defendant made input and RAM copies of the program (when it uploaded and accessed PROLOK on its computer). ${ }^{84}$ However, these copies were not made for the purpose of actually using PROLOK but solely for the purpose of analyzing plaintiff's program, and "analyzing" is not an "essential step" in the use of a copyrighted program. ${ }^{85}$ Second, defendant committed contributory copyright infringement by distributing RAMKEY to individuals who used RAMKEY to make and disseminate unauthorized copies of PROLOK and the PROLOK-protected proprietary programs ${ }^{86}$ Finally, to the extent that RAMKEY was based upon portions of PROLOK, RAMKEY constituted an unauthorized derivative work. ${ }^{87}$

While the defendant sought refuge in the provisions of section 117, it did so only in defense of plaintiff's first two claims. ${ }^{88}$ With respect to Vault's first claim, the court held that the defendant's uploading and accessing of a

78. Id.

79. Id. PROLOK functioned as a kind of "fingerprint" on floppy disks which housed the proprietary programs. Any copies made of these programs would only work as long as the original PROLOK floppy disk was also resident in the hard drive of the user's computer. Consequently, licensees could not make and disseminate fully functional copies of PROLOK protected programs unless they also parted with their original PROLOK floppy disk, in which case they could not use any copies of the proprietary programs they might retain. $I d$.

80. Id. at 257.

81. Id.

82. Id. at 257-58.

83. Id. at 258 .

84. Id.

85. Id.

86. Id.

87. Id.

88. Id. at 259 . 
legitimately obtained copy of PROLOK was indeed sanctioned by section $117{ }^{89}$ Notwithstanding the fact that defendant's ultimate purpose was not to use PROLOK for "copy-protect" purposes, the act of uploading and accessing a legitimately acquired software program is itself non-infringing conduct:

Even though the copy of Vault's program made by Quaid was not used [for copy-protect purposes] . . . and was, indeed, made for the express purpose of devising a means of defeating its protective function, the copy made by Quaid was "created as an essential step in the utilization" of Vault's program. Section 117(1) contains no language to suggest that the copy it permits must be employed for a use intended by the copyright owner, and, absent clear congressional guidance to the contrary, we refuse to read such limiting language into this exception. ${ }^{90}$

The court appropriately distinguished the act of uploading and accessing a software program from the eventual use or uses to which the program might be put. ${ }^{91}$ Section 117 expressly authorizes the creation of input and access copies as a necessary step in using a software program. ${ }^{92}$ Absent some additional manifest activity, the subjective "mental intention" underlying the user's uploading and accessing activities - the user's reason for using the program - is irrelevant. Thus, uploading and accessing a legitimately acquired program is permissible per se. ${ }^{93}$

If the court held otherwise, software users might be held liable for "premeditated infringement" (i.e., the intention to use a RAM copy toward some actually infringing conduct) or, for that matter, for uploading and accessing a program solely to demonstrate its features (inasmuch as program demonstration is not the subjective function that most programs are designed

89. Id. at 261 .

90. Id.

91. Id.; accord Storage Tech. Corp. v. Custom Hardware Eng'g \& Consulting, Inc., 431 F.3d 1374 (Fed. Cir. 2005) (holding that where maintenance programs are intermixed with licensed substantive programs, RAM copying of maintenance programs is an essential step in uploading and accessing the licensed programs). But cf. Sega Enters. Ltd. v. Accolade, Inc., 977 F.2d 1510, 1518 (9th Cir. 1993) ("[T]he Copyright Act does not distinguish between unauth orized copies of a copyrighted work on the basis of what stage of the alleged infringer's work the unauthorized copies represent. ... On its face, [section 106] unambiguously encompasses and proscribes 'intermediate copying."' (citations omitted)). Thus, each act of copying is individually assessed and can provide a basis for an infringement claim. The fact that some copying by the defendant is lawful (such as copying permitted by section 117) is not dispositive as to other copying, and vice versa.

92. See Vault Corp., 847 F.2d at 261.

93. See Wall Data Inc. v. L.A. County Sheriff's Dep't, 447 F.3d 769, 784 (9th Cir. 2006) (“The 'essential step' defense also ensures that a software user does not infringe when the user 'copies' the software from the computer's permanent storage ... onto its active memory [and] allows the owner to make a copy of the computer program if the copy is 'for archival purposes only ...."'). 
to perform). On the other hand, section 117 does not authorize a user to transmogrify permissible RAM copying into concrete infringing conduct. ${ }^{94}$ Thus, once the user actually creates and disseminates unauthorized copies to a third party, her conduct is outside the safe harbor of section 117, as such copies would be neither archival copies nor copies made in order to use the program.

The court also denied Vault's claims for contributory infringement. ${ }^{95}$ The court held that because fully functional archival copies of PROLOK-protected programs could be made only by using RAMKEY, RAMKEY was capable of both infringing and non-infringing uses. ${ }^{96}$ Thus, the distribution and use of RAMKEY was permitted under section 117 as the only method available through which a user could engage in her archival copying privileges. ${ }^{97}$

Finally, with regard to the plaintiff's derivative work claims, as indicated above, the defendant did not claim that RAMKEY constituted a section 117 adaptation. ${ }^{98}$ Instead, the defendant argued only that RAMKEY did not constitute a derivative version of PROLOK in contravention of section $106 .{ }^{99}$ Consequently, the court had no occasion to determine whether the defendant's incorporation of parts of PROLOK into RAMKEY was an "essential step utilization" of PROLOK such that RAMKEY might be eligible for treatment as a privileged adaptation. ${ }^{100}$ Instead, the court ruled only that RAMKEY was not a derivative version of PROLOK because RAMKEY performed an entirely different function than that performed by PROLOK. ${ }^{101}$

94. See, e.g., Sega Enters. Ltd., 977 F.2d at 1521 ("Section 117 defines a narrow category of copying that is lawful per se.").

95. Vault Corp., 847 F.2d at 262.

96. Id.

97. Id. at 262,264. The court's invocation of the substantial non-infringing use doctrine of Sony Corp. of Am. v. Universal City Studios, Inc., 464 U.S. 417, 441-48 (1984), to implement the mandates of section 117 is logical; archival copying, an express user privilege under the copyright law, is certainly at least as "substantial" a use as the VCR time-shifting use at issue in Sony.

98. Vault Corp., 847 F.2d at 259.

99. Id.

100. Id. at 268. Given the court's disposition of Vault's contributory infringement claims, however, it may well have found RAMKEY to be a permissible adaptation, "created as an essential step in the utilization" of PROLOK. Id. at 270. "We read the statute . . to authorize the owner of the PROLOK diskette to copy both the PROLOK program and the [protected] software program for any reason so long as the owner uses the copy for archival purposes only and not for an unauthorized transfer." Id. at 266 (footnote omitted). Because archival copying is expressly permitted under section 117, and because RAMKEY was the only means by which archival copies of PROLOK protected programs could be made, the creation/use of RAMKEY arguably constituted an "essential step utilization" of PROLOK and/or a PROLOK protected program.

101. Id. at 268. The court's different-function versus market-impact analysis, and its corresponding conclusion that RAMKEY was not a derivative version of PROLOK, is explored in infra Part IV, as part 
In Sega Enterprises Ltd. v. Accolade, Inc., ${ }^{102}$ section 117 was raised in defense of the unauthorized disassembly of a computer program. ${ }^{103}$ The defendant obtained copies of Sega's game programs and disassembled and analyzed them in order to develop its own game programs that were compatible with Sega's video game console. ${ }^{104}$ Sega sued for copyright infringement, citing defendant's "intermediate copying" ${ }^{105}$ actual disassembly of its programs as acts of infringement. ${ }^{106}$ In its defense, the defendant asserted that (i) it destroyed all of the "intermediate" copies it had made of Sega's programs, and none of its own final programs reproduced any parts of Sega's programs; and (ii) its disassembly activities were lawful per se, permitted under the fair use doctrine, and/or sanctioned by section $117 .{ }^{107}$

With respect to the defendant's section 117 defense, ${ }^{108}$ the court held that section 117 does not extend to disassembly of a software program: "We think it is clear that [the defendant's] use went far beyond that contemplated by CONTU and authorized by section 117 . Section 117 does not purport to protect a user who disassembles object code, converts it from assembly into source code, and makes printouts and photocopies of the refined source code version." 109

In essence, the court found the defendant's activities to be unrelated to any use of Sega's video game program to perform its intended function, whether "as is" or in a manner to accommodate defendant's individual needs in connection with that function. ${ }^{110}$ Instead, defendant's activities were part of its efforts to create new video game programs compatible with Sega's game console. ${ }^{111}$ If such activities (and/or any programs resulting therefrom) can be

of the discussion regarding the narrowing of the derivative work right in its application to software programs.

102. 977 F.2d 1510 (9th Cir. 1993).

103. Id. at 1520.

104. Id. at $1514-15$.

105. In studying plaintiff's programs, defendant uploaded the programs, accessed them, and made other temporary copies, all of which were destroyed upon the completion of defendant's analysis. $I d$. at 1518.

106. Id. at 1517 .

107. Id. at $1517-18$.

108. With respect to defendant's non-section 117 defense, the court held that defendant's intermediate copying and disassembly activities were permitted under the fair use doctrine, as the only means by which the public could gain access to the unprotected elements in Sega's programs. Id. at 1521-28.

109. Id. at 1520 .

110. See id. at 1520-21.

111. See id. 
insulated from infringement liability, section 117 user privileges do not provide the means by which to do so. ${ }^{112}$

Recently, in Madison River Management Co. v. Business Management Software Corp., ${ }^{113}$ a software licensee sought to invoke the section 117 user privileges in connection with its use of a licensed program to gain access to an underlying proprietary database. ${ }^{114}$ The licensee also duplicated the protected, non-literal structure of the licensed program in order to create additional software programs. ${ }^{115}$ The court found no appropriate connection between the licensee's use of the copyrighted program to gain access to the licensor's proprietary database and the proper use of the licensor's copyrighted program:

There are no allegations that [the licensee] could not make actual use of the ... software without copying the [protected] database, such as the necessary copying of software onto a computer's hard drive as part of the installation process. Instead, the [unauthorized copy] was made to "help [the licensee] more effectively utilize [the software]," which as a matter of logic and of definition forecloses it from being necessary or absolutely essential. ${ }^{116}$

In essence, while the licensee certainly benefited from its unrestricted access to the licensor's proprietary database, this was in no way an aspect of the

112. See id. ("[W]e reject [plaintiff's] contention that the assertion of a fair use defense in connection with the disassembly of [software] object code is precluded by [section 117 of the copyright] statute. [In essence plaintiff] argues that not only does section 117 . . not authorize disassembly of object code, but it also constitutes a legislative determination that any copying of a computer program other than that authorized by section 117 cannot be considered a fair use of that program. ... Nothing in the language or the legislative history of section 117, or in the CONTU Report, suggests that section 117 was intended to preclude the assertion of a fair use defense with respect to uses of computer programs ... not covered by section $117 \ldots$... Moreover, ... [s] ection 117 defines a narrow category of copying that is lawful per se.... Section 107 , by contrast, establishes a defense to an otherwise valid claim of copyright infringement. It provides that particular instances of copying that otherwise would be actionable are lawful, and sets forth the factors to be considered in determining whether the defense applies." (emphasis in original) (citations omitted)).

113. 387 F. Supp. 2 d 521, 537-39 (M.D.N.C. 2005).

114. Id. at 537 .

115. $I d$. at 540-541. The licensed software program performed a data organization function through which, among other things, it organized the licensee's internal information pursuant to the licensor's proprietary organizational framework. The licensee not only made use of the program to improve its use of its own internal information, but it also used the program to gain access to and to duplic ate the licensor's proprietary organizational framework. This enabled the licensee to gain the benefit of the licensor's organizational structure without relying upon the licensed program. In addition, the licensee duplicated the structure of the software program itself, including expressive elements of the structure, in creating its own data organization software programs.

116. Id. at 538 . 
normal use of the software program's organizational function. ${ }^{117}$ Rather, the licensee had engaged in a kind of reverse engineering of the program, so as to gain unrestricted access to the licensor's attendant proprietary secrets. ${ }^{118}$

In addition, the court held that the licensee's duplication of the program's structure, in developing its own data organization programs, was also activity outside the adaptation privilege. ${ }^{119}$ Rather than an "essential step utilization," the court found the licensee's conduct to constitute unauthorized reproduction of the non-literal structure of the copyrighted program. ${ }^{120}$ "When [the licensee] completed its [own] program, it [incorporated the licensor's] technical specifications.... [The licensee's] copying of the technical designs and specifications would constitute copying of the nonliteral elements of the software, which include its structure. ... Such copying is not excepted use under the Copyright Act." ${ }^{21}$ Thus, similar to the courts in Apple and Sega, the Madison River court refused to extend the section 117 privileges to activities aimed at creating new programs that use protected elements of pre-existing copyrighted software programs. Collectively, these judicial applications of section 117 provide connotation for the "essential step utilization" provision of the statute. In addition, they establish some general parameters for the kinds of substantive modifications that will qualify as privileged "adaptations."

At the same time, these cases leave some important questions unanswered, particularly with respect to the extent of a software users' privileges to alter, enhance, or otherwise "customize" a program's performance. ${ }^{122}$ In addition, the vitality of the "for personal or internal use only" requirement is not entirely clear. For one thing, the statute itself provides some flexibility under the requirement. ${ }^{123}$ Moreover, while Foresight and Apple hold personal use as essential, the reasoning in Vault suggests that

\section{See id.}

118. See id.

119. Id.

120. Id. at $540-41$.

121. $I d$. at 541 (citations omitted).

122. Of course, to the extent that a modified program (whether or not a derivative work) is not created as an essential step in the utilization of the original program and consists of modifications unrelated to the program's performance of its subjective function, the work would not qualify for the adaptation privilege. Thus, although many adaptations are also derivative works, there are many modified programs and/or derivative works that do not qualify as section 117 adaptations.

123. See 17 U.S.C. $\$ 117$ (a) (2006) ("[I]t is not an infringement for the owner of a copy of a computer program to make or to authorize the making of another copy or adaptation .....”); see also supra note 61. 
there may be circumstances under which the privilege would apply to an adaptation made with the intention to disseminate it to other users. ${ }^{124}$

Some of the more recent cases involving section 117 have begun to address these issues. In response to the unauthorized modification of their programs, some copyright holders have argued that the resulting works constitute derivative works and such "program customization" goes too far because the creation of derivative works is not authorized by section 117. In addition, the ability of users to share the modified programs has been a point of contention. The opinions resolving these disputes provide further clarification of the adaptation privilege.

Delineating the Adaptation Privilege: "Customization," Distribution, and the Derivative Work Right

In Aymes v. Bonelli, ${ }^{125}$ the plaintiff copyright holder developed a software program which facilitated business inventory and sales record keeping. ${ }^{126}$ The plaintiff's licensee, a swimming pool retail chain, made modifications to keep the program current with its daily business activities and to accommodate its hardware upgrades. ${ }^{127}$ Insisting that such modifications were beyond the scope of the license agreement, the plaintiff commenced litigation for copyright infringement. ${ }^{128}$

Perhaps mindful of section 117 precedent, the plaintiff did not challenge its licensee's right to make modifications per se, but rather that the modifications resulted in the creation of an unauthorized derivative work. ${ }^{129}$ For its part, the licensee conceded that its modifications resulted in the

124. While the RAMKEY program in Vault performed a different (indeed, an opposing) function from that of its progenitor PROLOK, it also provided the only means for making archival copies of PROLOK protected programs, a "generic function" not merely permitted by section 117 but actually guaranteed by it. Arguably RAMKEY could therefore be considered an essential step in the utilization of such programs, and ultimately a section 117 adaptation. On the other hand, if such an entirely different work can qualify as an adaptation, the privilege might very well swallow the derivative work right altogether. The analysis in Vault is not dispositive, however, because RAMKEY was assessed as a possible derivative work and also as a fair use method for achieving section 117's objectives, but not as a possible 117 adaptation. See Vault Corp. v. Quaid Software Ltd., 847 F.2d 255, 267 (5th Cir. 1988).

125. 47 F.3d 23 (2d Cir. 1995).

126. $I d$. at 24 .

127. $I d$.

128. $I d$.

129. "[Defendant] does not dispute that it altered [plaintiff's program] and thereby created a 'derivative work' from the original ... program that [plaintiff] developed. . . . Unless excused by another statutory provision, [defendant's] modification would constitute an infringement of [plaintiff's] copyright." Id. at 25 . 
creation of a derivative version of plaintiff's program but nonetheless argued that its modifications were sanctioned by section $117 .{ }^{130}$

Reminiscent of the holding in Foresight, the court agreed with the licensee that the changes were necessary to its individual use of the program:

[Defendants] as rightful owners of a copy of [plaintiff's program] did not infringe upon [plaintiff's] copyright, because the changes made to [the program] were necessary measures in their continuing use of the software in operating their business. . . The district court found that [defendant] used the program for internal purposes only and did not distribute the program to [third parties]. Nor does it appear that the modifications to the program were for any purpose other than [defendant's] internal business needs. The original program made provisions for late charges, and [defendant] did alter [the program] to keep it current from year to year to maintain the viability of the original software when [defendant] upgraded its computer to accommodate successive generations of IBM systems. ... Moreover, both parties knew that modifications would be essential for the continued functioning of the program on an upgraded computer system. ... ${ }^{131}$

Thus, the Aymes court implicitly acknowledged that privileged adaptations can encompass derivative works. Nonetheless, an unauthorized work's coterminous qualification as both an adaptation and a derivative work does not deprive it of the section 117 adaptation privilege.

In Krause v. Titleserv, Inc., ${ }^{132}$ the Second Circuit again confronted the adaptation versus derivative work interface. As in Aymes, the plaintiff in Krause developed a business accounts software program which it licensed to the defendant. ${ }^{133}$ When business disagreements developed between the parties, however, plaintiff brought suit for infringement, alleging that the defendant had made unauthorized modifications to the program that constituted the creation of a derivative work. ${ }^{134}$

Once again, the court considered the relevance of the modifications to the defendant's routine use of the program to accommodate its individual needs: "Many routine functions such as the addition of a new customer or a change of a customer address could be performed only by changing the source code. In addition, changes were required to fix bugs from time to time to keep the system from crashing." 135 Concluding that the "[i]nability to modify the source code would have severely limited the value of those programs to

130. $I d$.

131. Id. at 26-27 (citations omitted).

132. 402 F.3d 119 (2d Cir. 2005).

133. Id. at 120 .

134. Id. at 120-21.

135. Id. at 121 . 


\section{[defendant], ${ }^{\prime 136}$ the court considered whether the licensee's modifications served legitimate section 117 purposes:}

The modifications allegedly made by [defendant] ... fall into four main categories: (1) correcting programming errors or "bugs," which interfered with the proper functioning of the programs; (2) changing the source code to add new clients, insert changed client addresses, and perform other routine tasks necessary to keep the programs up-to-date and to maintain their usefulness[;] ... (3) incorporating the programs into [defendant's new operating system]; and (4) adding capabilities, such as the ability to print checks, and, to a limited degree, allowing customers direct access to their records . . . ${ }^{137}$

The court found the first three categories of modifications to fall readily within the ambit of section 117 as modifications necessary to use (and maintain) the program. ${ }^{138}$ With regard to the fourth category, the court observed that the issue hinged upon whether such "extended customization" could also be considered an essential use of the program:

[Plaintiff] asserts that the CONTU . . . Commission was primarily concerned with compatibility as between program and computer, which was of particular concern at the time the [CONTU] Report was issued. ...

Other passages of the report, however, describe the right to modify programs in a manner that goes far beyond concern with compatibility and strongly suggests that the writers of the CONTU Report envisioned a loose concept of necessity that would encompass our very issue - the addition of features so that a program better serves the needs of the customer for which it was created. . . "Thus, a right to make those changes necessary to enable the use for which it was both sold and purchased should be provided. The conversion of a program from one higher-level language to another to facilitate use would fall within this right, as would the right to add features to the program that were not present at the time of rightful acquisition." 139

136. $I d$.

137. Id. at 125 .

138. Id. at 125-26 ("As for the first two types of modifications, ... the undisputed facts establish[] that these modifications constituted 'essential step[s] in the utilization of the computer program[s] in conjunction with a machine.' The fixing of bugs was done so that the programs would continue to function.... [Defendant's] modification of the source code to reflect such business changes as the addition of new customers and changed customer addresses also comes within the scope of the modifications ... designed to keep the software in step with changes in the defendants' business. As for the third type of modifications, involving adaptation of the programs so that they would function on [defendant's] new Windows-based system, ... we . . conclude . . that such adaptation qualifies under $\S 117(a)(1)$ as an 'essential step."' (citations omitted)).

139. Id. at 128 (citing CONTU FINAL REPORT, supra note 2, at 25); see also Evolution, Inc. v. Suntrust Bank, 342 F. Supp. 2d 943, 958 (D. Kan. 2004) ("Section 117 permits a licensee to modify licensed software in order to enhance its functionality or make it usable to the licensee."). 
Consequently, the court held that all of defendant's modifications came within the section 117 privilege: "We can see no reason why the modest alterations to [defendant's] copies of the programs should not qualify. We need not address whether other types of improvements might be too radical, or might fail to qualify because they somehow harm the interests of the copyright owner." 140

With respect to plaintiff's claim that the modified program also constituted a derivative work, the court, in finding for the defendant, implicitly held either that the modifications did not result in a derivative work, or that even if the resulting work was a derivative work, that fact did not render it ineligible for the adaptation privilege. ${ }^{141}$ Given the nature of the changes to the program and the low threshold for creating a derivative work under section 101 , it seems unlikely that the court did not regard the modified program as satisfying the elements of a derivative work. ${ }^{142}$ Consequently, Krause appears to follow the rationale of Aymes in this regard.

Finally, the plaintiff also alleged that even if the modified program qualified for the privilege, the defendant forfeited the privilege when it disseminated it to its banking clients. ${ }^{143}$ While the language of section 117 creates an ambiguity with respect to the substantive boundaries of adaptations, that language expressly dictates a specific limitation upon the use of adaptations, namely that they cannot be distributed without the permission of the copyright holder of the original program. ${ }^{144}$ Recognizing that dissemination to third parties contravenes the express provisions of the statute, the court nonetheless held that such dissemination was permissible under the circumstances:

140. Krause, 402 F.3d at 128-29.

141. See id. at 125-29.

142. Id. As discussed in Part IV infra, the tendency of some courts to resolve infringement disputes without specifying which section 106 rights have or have not been infringed frequently leads to a lack of clarity in the law. See, e.g., Bridgeport Music, Inc. v. Dimension Films, 410 F.3d 792, 804, (6th Cir. 2005); see also Lateef Mtima, Tasini and Its Progeny: The New Exclusive Right or Fair Use on the Electronic Publishing Frontier?, 14 Fordham Intell. Prop. Media \& Ent. L.J. 369, 449-58 (2004). In Krause, it would have been useful to know specifically why defendant's modifications did not infringe the derivative work right - i.e., whether the court found that the revised program was a privileged adaptation but not a derivative work, or that the revised program was both an adaptation and a derivative work, but its adaptation status "trumps" its infringement upon the derivative work right.

143. Krause, 402 F.3d at 129.

144. 17 U.S.C. 1117 (b) (2006); see also ITOFCA, Inc. v. Mega Trans Logistics, Inc., 322 F.3d 928 , 929-30 (7th Cir. 2003) (noting that a right to prepare an adaptation or a derivative work does not include the right to disseminate said adaptation or derivative work). 
Although [plaintiff's] argument is slightly stronger with respect to his allegation that [defendant] also made the [modified] programs available to two client banks through a dial-up connection, we find this argument insufficient as well. . . .

The programs [plaintiff] designed ... were designed for the processing of transactions relating to [defendant's] relationship with its customers. ... [I]t seems ... to make little difference whether the programs are accessed and operated by [defendant's] personnel or the personnel of the customer in carrying out or checking on its transactions with [defendant]. What is important is that the transaction for which the programs are used is the type of transaction for which the programs were developed. Where the programs were designed to aid [defendant] in ordering its transactions with client banks, an adaptation which allows the programs to be accessed directly . . by the client bank, rather than exclusively by [defendant's] personnel at the request of the client bank, does not seem to us to violate $\S 117(\mathrm{a})(1)$ 's "in no other manner" requirement. ${ }^{145}$

The decisions in Aymes and Krause add delineation to the general parameters for permissible modifications under the adaptation privilege and confirm the overlap between the adaptation privilege and the derivative work right. Further, the Krause decision echoes the reasoning in Vault regarding circumstances under which dissemination of a privileged adaptation to third parties might be appropriate. Given the recognition of an overlap between adaptations and derivative works, however, the ability to disseminate adaptations poses a genuine threat to the copyright holder's derivative work interests. If adaptations can be shared with third parties, the adaptation privilege could be broadly applied so as to usurp many of the property interests the derivative work right is intended to preserve for the copyright holder.

As discussed in Part III, the judicial extension of the adaptation privilege into the realm of derivative works can be reconciled with the derivative work rights and interests of copyright holders. Proper construction of the express deference afforded by section 117 to the exclusive right of distribution, as a means for protecting the copyright holder from undue impact upon the market for the original program, pragmatically reconciles the adaptation privilege as applied by the courts with the copyright holder's exclusive right to create derivative versions of her work.

\section{The "Distribution Prohibition" as Cipher: Revealing the Derivative Work Right in Section 117}

Section 117 expressly prohibits the dissemination of adaptations to third parties. "Adaptations . . . prepared [under these provisions] may be 
transferred only with the authorization of the copyright owner." many adaptations also constitute derivative works, the adaptation privilege encroaches upon the copyright holder's interests under the derivative work right. The prohibition against the distribution of adaptations, however, serves to protect the copyright holder's interests in derivative commercial markets for her work even where the modifications to the underlying program are extensive. ${ }^{147}$

The express "distribution prohibition" contained in section 117 pragmatically balances the interests of software users and copyright holders by recognizing that the interests of copyright holders are not necessarily harmed by the mere creation of derivative versions of their works. Indeed, unauthorized derivative versions of protected works are created every day; ${ }^{148}$ however, their creation is usually indifferent to the rights of copyright owners, unless the user seeks to distribute an unauthorized derivative work, particularly on a widespread or commercial basis.

As the CONTU Commission observed, the unique nature of software programs as copyrightable works necessitates that the software-using public have some special flexibility with regard to the modification of software programs in connection with their routine use. The distribution prohibition serves to balance this social utility need against the author incentives provided by the derivative work right. Section 117 authorizes the creation and use of adaptations, including adaptations that also constitute derivative works, but prohibits their unauthorized distribution as an undue impairment of the copyright holder's interests in derivative markets for the underlying program. ${ }^{149}$ The distribution prohibition thus assures that "adaptationderivative works" will have no more impact upon the commercial market interests of copyright holders than the private margin notations that "transform" traditional copyrighted works every day.

146. $\S 117(b)$.

147. See 2 Nimmer \& Nimmer, supra note $2, \S 8.08$ [B][3], at 8-142.3.

148. See Foresight Res. Corp. v. Pfortmiller, 719 F. Supp. 1006, 1009 (D. Kan. 1989) ("The comparison of [modifying programs] to extensive marginal note-taking in a book is appropriate: note-taking is arguably the creation of a derivative work, but unless the note-taker tries to copy and vend that work, the copyright owner is unlikely to be very concerned." (quoting CONTU FINAL REPORT, supra note 2, at 26)).

149. See Paul Goldstein, Derivative Rights and Derivative Works in Copyright, 30 J. COPYRIGHT SoC'Y 209, 216 (1983) ('“S]ection 106(2)'s grant of the exclusive right 'to prepare derivative works based on upon the copyrighted work' enables prospective copyright owners to proportion their investment in a work's expression to the returns expected not only from the market in which the copyrighted work is first published, but from other derivative markets as well."). 
Broadly construed, the decision in Krause seems to upset the delicate balance achieved by section 117 . Indeed, on its face, the decision appears to be in direct contravention of the express language of the statute. Moreover, disregarding the distribution prohibition further complicates the problem of distinguishing adaptations from derivative works. Whereas the acknowledgment that adaptations and derivative works substantively overlap has some minimal impact upon the copyright holder's derivative property interests, that impact is negligible if adaptations can only be utilized by the users who create them. If the section 117 distribution prohibition is disregarded, however, the threat to the copyright holder's derivative work interests becomes real. Indeed, in some cases, the adaptation privilege may invite illegitimate dissemination. By definition, the user has "improved" the program, and there are likely to be both current users as well as potential customers for the original program who would be interested in these additional features and capabilities.

Fortunately, Krause can be reconciled with the social balancing objectives of section 117 as well as prior section 117 case law. Although the Krause court found distribution of an adaptation permissible under the statute, the court emphasized that its holding was based upon the absence of any cognizable threat to the copyright holder's commercial market interests:

A different scenario would be presented if [defendant's] alteration somehow interfered with [plaintiff's] access to, or ability to exploit, the copyrighted [program] that he authored, or if the altered copy of [plaintiff's program] were to be marketed by [defendant]. But on our facts ... [t] he changes made by [defendant] were made only to its copies of [plaintiff's] programs. [Plaintiff] enjoyed no less opportunity . . . than before, to use, market, or otherwise reap the fruits of the copyrighted programs he created. ${ }^{150}$

Thus, the court did not disregard the distribution prohibition entirely but rather determined that under the circumstances the purpose of the prohibition would be achieved notwithstanding a limited distribution of the subject adaptation. ${ }^{151}$ Krause can therefore be read to hold that before an unauthorized distribution of an adaptation is systematically precluded by a court, its impact upon the commercial market interests attendant to the underlying program should be specifically assessed. Applied in this manner, Krause furthers the copyright constituent balancing objectives of section 117 by permitting the distribution of an adaptation when incidental to (arguably, 
an essential step in) the proper use of the underlying program, but only to the extent that such distribution does not unduly harm the commercial market interests of the copyright holder in the original work. ${ }^{152}$

Revisiting the previously considered section 117 decisions confirms that Krause is at least consistent with the rationale of these cases. In Foresight, the court emphasized that the threat to the copyright holder's interests arises not so much from the creation of an adaptation, but from its commercial distribution:

[A]s noted in the findings of fact herein, the [modified program] is used solely in-house by [defendant] and has not been released to any other purchaser of plaintiff's products. ... Nonetheless, and although there was no evidence that defendant has sold or intends to sell these enhancements to any other party, the court will enjoin defendant from selling these particular enhancements of plaintiff's products to other entities. ${ }^{153}$

In Apple, the court held the defendant's conduct to be outside the protective ambit of section 117, in part because "[defendant] has not confined its use of the copy of [the plaintiff's] copyrighted programs to [defendant's] own use. It has made [the plaintiff's] programs available to others. Thus, ... [the defendant] cannot bring itself within [s]ection 117." 154 Obviously, a distribution to "make-your-own-Apple-computer" customers has an entirely different market impact than that of the adaptation sharing in Krause.

In Aymes, the court also upheld the defendant's invocation of section 117, again emphasizing that the subject adaptation, although somewhat comprehensive, had not been commercially distributed:

The district court found that [defendant] used [the modified program] for internal business purposes only and did not distribute the program to its subsidiaries. . . Nor is there evidence that the modified program was marketed, manufactured, distributed, transferred, or used for any purpose other than [defendant's] own internal business needs. ... (" $[\mathrm{T}]$ he copy authorized by Section 117 must be made only for the owneruser's internal use."). ${ }^{155}$

152. See Universal City Studios, Inc. v. Sony Corp. of Am., 659 F.2d 963, 965 (9th Cir. 1981) ("[The copyright] scheme relies on the author to promote the progress of science by permitting him to control the cost of and access to his novelty. It is based on the premise that the exclusive right granted by the copyright laws "will not impose unacceptable costs to society in terms of limiting access to published works or pricing them too high."'), rev'd on other grounds, 463 U.S. 1226 (1983); Fox Film Corp. v. Doyal, 286 U.S. 123, 127 (1932). See also Berlin v. E.C. Publ'ns, Inc., 329 F.2d 541 (2d Cir. 1964); Mazer v. Stein, 347 U.S. 201, 219 (1954).

153. Foresight Res. Corp., 719 F. Supp. at 1009-10 (emphasis added).

154. Apple Computer, Inc. v. Formula Int'1, Inc., 594 F. Supp. 617, 622 (C.D. Cal. 1984).

155. Aymes v. Bonelli, 47 F.3d 23, 27 (2d Cir. 1995) (citation omitted). 
Thus, Krause merely clarifies the rationale of the prior decisions. Lest the distribution prohibition be vitiated to impede the overarching goals of section 117 , it should not be rigidly applied so as to hamper the routine use of copyrighted software. ${ }^{156}$ As was the case in Krause, where the function of a software program is to maintain client account information, and said program is properly adapted by the user to accommodate changes in its internal administrative structure, it is appropriate to allow the user to provide access to the adaptation to its clients who personally update their individual account information. Unauthorized "distributions" of this sort should only be prohibited when they are actually harmful to the legitimate commercial market interests of the copyright holder in the original program. ${ }^{157}$

Just as the earlier section 117 decisions added substance to the "essential step utilization" requirement and thereby facilitated widespread use of software programs, the decisions in Aymes and Krause regarding the adaptation versus derivative work interface and the distribution prohibition similarly elucidate the adaptation privilege. An inelastic application of the distribution prohibition undermines the specific social balancing purposes of section 117 as well as the overarching goals of the copyright law as a whole..$^{158}$

156. Dun \& Bradstreet Software Servs., Inc. v. Grace Consulting, Inc., 307 F.3d 197, 206 (3d Cir. 2002) ("Beginning with the federal Constitution, copyright protection has enjoyed a revered place in our national legal system and in the development of the arts, sciences, the economy, and industrialization of our nation. Under Constitutional mandate, Congress is specifically empowered 'To promote the Progress of Science and useful Arts, by securing for limited Time to Authors and Inventors the exclusive Right to their respective Writings and Discoveries.' Congress enacted the first copyright statute as early as 1790 . The existing copyright laws are codified in the Copyright Act of $1976 \ldots$. . This Act contains a complete revision of copyright law in response to far reaching new developments made in technology and the sciences." (citation omitted)).

157. Krause v. Titleserv, Inc., 402 F.3d 119, 128-30; Sony Corp. of Am. v. Universal City Studios, Inc., 464 U.S. 417, 450-51 (1984) (holding that where the unauthorized use of a copyrighted work is noncommercial, actual harm to the copyright holder's interested must be demonstrated to enjoin that use).

158. Durham, supra note 21, at 852-53 ("If the rights of authors are too weak, copyists reap the benefits of their work, and deny authors the financial rewards necessary to spur their labors. Authors produce less and the intellectual life of the nation suffers. Yet 'the Progress of Science' also depends upon some freedom to build upon existing works of authorship. Works of art allude to prior works, established styles and familiar subject matter; factual works benefit from existing research; works of scholarship and criticism, to the extent they refer to some prior work, often reproduce a portion of that work in order to make their point. If the law allowed authors to prevent such uses of their work, the harm would be immeasurable." (footnotes omitted)); Lawrence Lessig, Creative Economies, 2006 Mich. ST. L. Rev. 33, 42-43 ("Existing law . . . against the background of the old [analog] way copyrighted works were used, complemented each other. But existing law against the background of these new [digital] uses conflicts.... We need to get policymakers to recognize that this is not a question of whether you are in favor of 'piracy' or against 'piracy' - that is one very small part of the balance. It is, instead, also about whether [the public use of copyrighted works] ecology can survive."). 
Where the functions and characteristics of a copyrighted software program necessitate that privileged adaptations thereof be shared with a limited number of "essential" third parties, such "distributions" should be allowed as within the permissive ambit of section 117, absent some meaningful impact upon the copyright holder's commercial market interests.

This flexible interpretation of the distribution prohibition reflects a more socially cohesive construction of copyright law, one which regards the specific statutory objectives of ensuring comprehensive use of software programs and protecting author incentives as mutually reinforcing, as opposed to mutually exclusive. ${ }^{159}$ A flexible interpretation assures that software users will be able to utilize programs to perform specific functions for which they were acquired while protecting copyright holders from unfair competition from unauthorized derivative versions of their works. ${ }^{160}$

159. See generally Lateef Mtima, Introduction, Symposium on Intellectual Property and Social Justice, 48 How. L.J. 571, 573 (2005) ("American intellectual property law embodies a system of individual property rights carefully balanced against the public interest. Congress provides secular incentive to creators by granting them the 'exclusive right' to their works, that is, by recognizing individual property rights on behalf of creators in connection with the products of their intellectual labors .... In exchange for these property rights, the public is guaranteed access to a supply of original creative works, to use, enjoy, and draw upon in their own creative and educational pursuits."); Alyson G. Barker, Note, Patent Permanent Injunctions and the Extortion Problem: The Real Property Analogy's Preservation of Principles of Equity, 88 J. Pat. \& TRademark Off. Soc'y 256, 258-59 (2006) ("Courts handling real property cases have long considered a balancing of the equities when determining whether an injunction should issue in cases dealing with nuisance, encroachment, and violation of zoning laws .... [C] ]ourts have at times recognized that an overwhelming public or third-party interest compels the denial of an injunction even where the property owner's right to exclude has been established. By analogy, even where the [intellectual property holder's] exclusive ownership ... has been established, courts should balance the equities, and may at times find that equity demands the denial of [injunctive relief].").

160. Thus, the Krause approach implicitly acknowledges the role of law as intellectual property intermediary. See, e.g., Robert A. Heverly, Law as Intermediary, 2006 Мiсн. Sт. L. Rev. 107, 109 ("Along with libraries and librarians, radio and television station owners, newspaper and book publishers, Web search engines and directories, law also mediates cultural and information goods and content. Law is interposed between - or perhaps among - producers of such content or meaning and its receivers, users, reusers, and consumers. In other words, law is an intermediary.”). Judicial interpretation of the section 117 distribution prohibition determines the social utility range of adaptations. See, e.g., id. at 113, 127-28 ("[I]ntermediaries, in their gatekeeping role, may stop particular expression from being brought to the market. This might happen where a book or a music CD needs to be changed before a retail distributor is willing to release it.... [D] espite the variety of effects that intermediaries can have on content, content producers often have the choice of whether to deal with a particular intermediary. If one radio or television station will not show a particular program, the producer can offer it to others. . . Law, however, is not so readily bypassed. Because law is the only game in town when it comes to its provisions, where law has a particular effect, there are only two things a content producer can do to 'get around' it: bypass the law, and in so doing, violate it and risk punishment, or change the content so as to avoid law's effect, if possible.... Law as intermediary both has intermediary effects and makes it illegal to 'improperly' . . . avoid those effects. Law is a Super Intermediary, one that can only be legally avoided on its own terms." (footnotes 
Thus, a "practical-use versus market-impact" constituent balancing construction of section 117 can be used to navigate the overlap between adaptations and derivative works. The presence or absence of undue market impact determines the extent and application of the adaptation privilege. "Mere adaptations" are subject to the distribution prohibition, as clarified by Krause; limited sharing is permitted under appropriate circumstances. "Adaptation-derivative works" are divided into two categories: "market innocuous" adaptation-derivative works are also treated as adaptations (and again, are subject to the distribution prohibition), while "market pernicious" adaptation-derivative works are more appropriately treated as derivative works and thus subject to the copyright holder's exclusive rights. ${ }^{161}$ This distinction immunizes software users from challenges to their adaptation privileges based solely upon claims that their modifications constitute derivative works, while protecting copyright holders from surreptitious trafficking in unauthorized derivative programs, disguised as legitimate adaptations.

In sum, section 117 should be regarded as neither pro software user nor pro copyright holder, but rather as a balancing mechanism to achieve the overarching purposes of the copyright law as a whole. Judicial construction and application of the privilege may be synthesized and interpreted to provide the following four "adaptation rules of thumb":

- With respect to the "essential step utilization" prerequisite, inputting, accessing, and archival copying of a software program, as well as using the program to perform its subjective function ${ }^{162}$ as designed by the copyright holder, are per se "essential step utilizations," regardless of the user's subjective reasons for engaging in these uses of the program.

- In addition to modifications to achieve interoperability, the adaptation privilege extends to modifications which customize a program's performance of its subjective function to accommodate the user's individual needs regarding that function; where customization modifications result in the creation of a derivative work, the adaptation privilege will continue to apply unless the modifications unduly impede the commercial market for the underlying program, in which case the result may be assessed as a derivative work.

- Modifications to a copyrighted program must be undertaken for the user's personal or internal use in order to qualify for the adaptation privilege; however, where

omitted)). Thus, the Krause interpretation of section 117 assures the maximum socialutility for adaptations consistent with the rights and interests of copyright holders.

161. Derivative work characterization does not necessarily lead to preclusion of the modified program. The user may still assert a fair use defense, or, as proffered in Part IV infra, courts could assess the impact of the unauthorized derivative work upon the commercial market interests of the copyright holder.

162. For example, using a word processing program to perform document layout and other word processing and related tasks. 
distribution of an adaptation is necessary to an effective "essential step utilization" of a software program, such distribution should be permitted to the extent that it does not unduly impede the commercial market interests of the copyright holder in the original program.

- Modifications unrelated to the program's performance of its subjective function or undertaken in the creation of additional programs generally do not qualify for the adaptation privilege.

The foregoing "adaptation rules of thumb" reconcile the incentive objectives of the section 106 derivative work right with the social balancing goals of section 117. In sum, section 117 only authorizes essential adaptations, including adaptation derivative works, which do not unduly encroach upon the copyright holder's commercial market interests.

Where a modified program is determined ineligible for the adaptation privilege, it should be evaluated for treatment as a derivative work. ${ }^{163}$ As discussed in Part IV, however, just as the impact of the unauthorized work upon the market for the original program should be evaluated in determining whether the revised program is beyond the scope of the adaptation privilege, assessment of the market impact issue can also be helpful in determining whether the revised program should be considered a permissible or an impermissible derivative work.

\section{The Section 117 Sarcophagus: Uncovering a Derivative Work \\ Right (and Public Derivative Work Privilege) for Computer Software Programs}

As discussed in Parts II and III, the copyright constituent-social balancing objectives embodied within section 117 provide the basis for a practical demarcation between section 117 adaptations and section 106 derivative works. The desired balance of copyright constituent interests is maintained by excluding from the adaptation privilege "adaptation-derivative works" which unduly impact the commercial market for the original program so as to preserve the copyright holder's commercial market interests, particularly the market for derivative versions of her program. As discussed below, however, this socially assiduous application of section 117 need not be restricted to the issue of distinguishing privileged adaptations from infringing derivative

163. The modified program may constitute a non-literal copy or a derivative work. Moreover, it may or may not provide a basis for actionable infringement upon the copyright holder's rights; some infringement defense such as the fair use doctrine might be applicable, or as discussed below, courts should apply the proposed software derivative work right. 
works. It can also be utilized to address the larger problem of reconciling the need for socially productive user modifications of copyrighted software programs - the recognition of a "public privilege" to prepare derivative works - with the copyright holder's broad property interests under the derivative work right.

The social balancing function of section 117 can be drawn upon to narrow the derivative work right in its application to software programs. If an adaptation-derivative work's negative impact on the commercial market for a copyrighted software program can serve as the basis for denying it the benefits of the adaptation privilege, the same market impact assessment should provide a basis for permitting or prohibiting unauthorized derivative works in general. Restated in terms of the traditional derivative work right, an unauthorized version of a copyrighted software program which satisfies the definition of a derivative work should be precluded as infringing upon the copyright holder's derivative work right only if the unauthorized work has an undue impact on the commercial market for the original program. ${ }^{164}$

164. Congressional reconstruction and judicial reinterpretation of traditional copyright mechanisms to accommodate the special challenges presented by software programs and other new technologies is obviously not a new idea. See, e.g., Lotus Dev. Corp. v. Borland Int'l, Inc., 49 F.3d 807, 820 (1st Cir. 1995) (Boudin, J., concurring) ("Nothing in the language or legislative history of the 1976 Act ... suggests that Congress meant the courts to abandon [the] case-by-case [development of computer copyright jurisprudence]. Indeed, by setting up $\S 102$ (b) as a counterpoint theme [with respect to expression that constitutes a method of operation], Congress has arguably recognized the tension and left it for the courts to resolve through the development of case law. And case law development is adaptive: it allows new problems to be solved with help of earlier doctrine, but it does not preclude new doctrines to meet new situations."). See generally Jon M. Garon, Normative Copyright: A Conceptual Framework for Copyright Philosophy and Ethics, 88 CoRnell L. ReV. 1278, 1309-10 (2003) ("The role of the common law and legislature is to balance property and liability interests.... If all property is subject to the legal balance between the exclusive owner and the public, then intellectual property is merely the realm in which the balancing is most explicitly acknowledged. ... The Supreme Court has repeatedly recognized the power of Congress to adjust the balance of rights between authors, publishers, and the public.... The normative question is not whether such balancing can take place, but how to create a reasoned framework for setting or shifting the balance." (footnote omitted)); Pollack, supra note 29, at 2445 ("Since the advent of the Gutenberg printing press, copyright law and technology have been entangled in an ongoing legal chase. In order to advance the quintessential goal of American copyright law, . . . Congress constantly must balance the law's objectives: to promote widespread dissemination of original creative works, while providing incentives to authors and owners to create such works. New technological advances continuously upset this balance by facilitating the ability to copy works without permission from copyright holders .... However, as developments such as radio, television, and video have demonstrated, worries over the demise of copyright protection have been overstated. In fact, such technological developments usually have been met with a ceaseless round of amendments to the United States copyright laws." (footnotes omitted)). In some of the earliest disputes involving copyrights in software, the courts took the lead in adapting the traditional protection afforded against non-literal copying to accommodate the utilitarian structure of software programs. See, e.g., Computer Assocs. Int'1., Inc. v. Altai, Inc., 982 F.2d 693, 712 (2d Cir. 1992) 
This emphasis on the market impact of an unauthorized derivative work not only furthers the social balancing imperatives of section 117, but it is also consistent with the salient objectives of the derivative work right. The proposed software derivative work right and the corollary public derivative work privilege merely acknowledge that society has an equal interest in fostering the maximum exploitation of the utilitarian benefits of software programs and preserving adequate property right incentives for the creators of software programs. ${ }^{165}$ To attain these goals, the software-using public should be allowed to modify and build upon such copyrighted works to engage in the ordinary intended use of individual programs as well as create additional programs for other purposes, up to the point where these activities have an undue impact on the commercial market for the original work. Once an

("Congress has made clear that computer programs are literary works entitled to copyright protection. Of course, we shall abide by these instructions, but in so doing we must not impair the overall integrity of copyright law. While incentive based arguments in favor of broad copyright protection are perhaps attractive from a pure policy perspective ... ultimately, they have a corrosive effect on certain fundamental tenets of copyright doctrine." (citation omitted)). More recently, the Sixth Circuit undertook an aggressive reinterpretation of sound recording infringement in the digital sampling context. See Bridgeport Music, Inc. v. Dimension Films, 410 F.3d 792, 800-01 (6th Cir. 2005). The Sixth Circuit held that unauthorized sampling constitutes infringement of the derivative work right even if the sample is not audibly recognizable as being taken from the underlying work. See id. at 804 . Needless to say, the problem of adapting intellectual property postulates to the demands of the digital age is not limited to software issues or the copyright law. See, e.g., eBay, Inc. v. MercExchange, L.L.C., 126 S. Ct. 1837, 1840, 1842 (2006); Xuan-Thao N. Nguyen, Commercial Law Collides with Cyberspace: The Trouble with Perfection-Insecurity Interests in the New Corporate Asset, 59 WASH. \& LeE L. REV. 37 (2002).

165. See Twentieth Century Music Corp. v. Aiken, 422 U.S. 151, 156 (1975); 1 NimMER \& NimmER, supra, note $2, \S 1.03$ [A], at 1-89 ("[T] he authorization to grant to individual authors the limited monopoly of copyright is predicated upon the dual premises that the public benefits from the creative activities of authors ...."); Lessig, supra note 158, at 33 ("I want to get us to think about the two separate lives that creative work lives .... One life is the commercial life of the creative work. The second life we might call the 'beyond commercial' life. The commercial life of creative work depends upon the exclusive rights granted by copyright; the 'beyond commercial' life does not depend upon the exclusive rights granted by copyright.... This distinction between the two lives that creative work might go through is the distinction that makes possible the difference between bookstores and libraries. Bookstores are enabled by the [exclusive rights] life of creative work. Libraries are enabled by the non-[exclusive rights] life of creative work. The obvious point is that culture needs both."); Amy B. Cohen, When Does a Work Infringe the Derivative Work Right of a Copyright Owner?, 17 CARdozo ARTs \& ENT. L.J. 624 (1999) ("This protection is justified not merely to compensate authors for their labors, but to provide potential authors with the incentive to create works in order to enrich public knowledge and well-being."); L. Ray Patterson, Copyright and the "Exclusive Right" of Authors, 1 J. INTELL. Prop. L. 1, 41-42 (1993) (“[C]opyright law is more regulatory than proprietary in nature, for only the regulatory concept makes any sense in view of the three policies that the Copyright clause mandates: promotion of learning, protection of the public domain, and benefit to the author."); Litman, supra note 47, at 968 ("The public domain should be understood . . . a as a device that permits the rest of the system to work by leaving he raw material of authorship available for authors to use.”). 
unauthorized work becomes capable of such effect, however, it encroaches upon the copyright holder's commodification incentives and threatens the desired balance of copyright constituent interests. ${ }^{166}$

Thus, where a copyright holder complains of an unauthorized version of her software program, the first task is to determine the proper classification of the unauthorized work: Is it merely a base non-literal copy, or does it qualify as an adaptation or a derivative work? If the work qualifies as an adaptation or a derivative work, the question of actionable infringement under the proposed market impact test will turn on the work's impact upon the commercial market for the original program. Consequently, whether the defendant software user has overstepped the boundaries of her section 117 adaptation privileges or has undertaken a use or modification of a protected program for purposes unrelated to section 117, (for example, a modification which is not an "essential step utilization"), the dispositive infringement question is the same: What is the impact of the unauthorized work or version on the commercial market for the original software program? ${ }^{167}$

In shaping a new (or at least reconstituted) derivative work right for software programs, it is necessary to clarify what constitutes a derivative work within the meaning of the copyright law. Thereafter, mechanisms for identifying the commercial market (both direct and derivative markets) for a copyrighted work must be considered, including bases upon which to distinguish between legitimate copyright market expectations and attenuated "market reverberations" outside the copyright holder's incentive parameters. As indicated above, under the proposed software derivative work right, unauthorized derivative works which negatively impact legitimate copyright market expectations would be precluded, whereas unauthorized derivative works which affect only attenuated "market reverberations" would be permitted.

166. Of course, a finding of undue market impact in connection with an unauthorized derivative work does not compel a finding of infringement. The unauthorized work may still be defensible on the grounds of some substantive copyright defense such as fair use, the principal mechanism for balancing copyright constituent interests. See infra notes 253-56 and accompanying text.

167. In the absence of prohibitive market impact, the purpose and nature of the unauthorized work would remain dispositive as to its ultimate treatment. For example, although trivial changes will typically result in the creation of a non-literal copy, if the changes were undertaken as an essential step in the utilization of the original program, the result would be permitted as a privileged adaptation. 


\section{A. Constructing a Software Derivative Work Right}

\section{What Constitutes a Derivative Work?}

In constructing a derivative work right to accommodate software programs, it is helpful to begin with the statutory definition of derivative work. Section 101 of the Copyright Act provides as follows:

[A] work based upon one or more preexisting works such as a translation, musical arrangement, dramatization, fictionalization, motion picture version, sound recording, art reproduction, abridgment, condensation or any other form in which a work may be recast, transformed, or adapted. A work consisting of editorial revisions, annotations, elaborations, or other modifications which, as a whole, represent an original work of authorship is a "derivative work." 168

Whether the issue arises in connection with software programs or more traditional copyrighted works, the determination as to what uses of, or modifications to, a protected work will result in the creation of a derivative work is often a difficult task. ${ }^{169}$ For one thing, the statutory definition provides little guidance as to what kinds of uses or modifications would not qualify. ${ }^{170}$ Indeed, the list of works that have been determined to constitute derivative works within the province of the copyright holder's domain reflects virtually every kind of conceivable variation. ${ }^{171}$ Moreover, commentators and

168. 17 U.S.C. $\S 101(2006)$.

169. See, e.g., Greenberg v. Nat'l Geographic Society, 244 F.3d 1267 (11th Cir. 2001); Lee v. A.R.T. Co., 125 F.3d 580 (7th Cir. 1997); Mirage Editions, Inc. v. Albuquerque A.R.T. Co., 856 F.2d 1341 (9th Cir. 1989); Lone Ranger Television, Inc. v. Program Radio Corp., 740 F.2d 718 (9th Cir. 1984); Midway Mfg. Co. v. Artic Int'l, Inc., 704 F.2d 1009 (7th Cir. 1983); L. Batlin \& Son, Inc. v. Snyder, 536 F.2d 486 (2d Cir. 1976); Lewis Galoob Toys, Inc. v. Nintendo of Am., Inc., 780 F. Supp. 1283 (N.D. Cal. 1991); Nicolas, supra note 26, at 1-2 ("Derivative works are those works that have been derived from another, preexisting/underlying work. ... [W] hen a court is presented with a claim for . . infringement [of the derivative work right], it must determine whether the 'infringing' . . . work is in fact a 'derivative work' ... This determination, however, has been the subject of great disagreement among the courts." (footnotes omitted)); see also 1 NimMER \& NimmeR, supra note 2, § 3.03, at 3-10 to -22.7; Gold STEIN, supra note $26, \S 5.3 .1$, at 3-11 to -22.7 .

170. See, e.g., Micro Star v. Formgen Inc., 154 F.3d 1107, 1110 (9th Cir. 1998) ("The statutory language is hopelessly overbroad, however, for "[e]very book in literature, science and art, borrows and must necessarily borrow, and use much which was well known and used before." (quoting Emerson v. Davies, 8 F. Cas. 615, 619 (C.C.D. Mass. 1845) (No. 4436))).

171. See, e.g., Value Group, Inc. v. Mendham Lake Estates, L.P., 800 F. Supp. 1228, 1233 (D.N.J. 1992 ) (photocopy of a copyrighted sales brochure that contained a depiction of copyrighted architectural plans held to be a derivative work); C Tek Software, Inc. v. New York State Bus. Venture P'ship (In re C Tek Software, Inc.), 127 B.R. 501, 506-07 (Bankr. D.N.H. 1995) (licensee created a derivative work by "debugging" licensed software); NBC, Inc. v. Sonneborn, 630 F. Supp. 524, 532 (D. Conn. 1985) (a 1960 
the courts alike express considerable disagreement as to the requisite elements of a derivative work under the copyright law. ${ }^{172}$

Further complicating matters is the overlap between the derivative work right and the right of reproduction, which has given rise to additional ambiguities regarding the requisite elements of a derivative work. ${ }^{173}$ Although the reproduction right initially precluded only literal copying, ${ }^{174}$ it was eventually expanded to encompass "non-literal" reproduction, which includes not only "inexact copies," but also the use of protected elements of a work without copying those elements verbatim. ${ }^{175}$ At the same time, the

telecast of "Peter Pan," preserved on tape, held to be a derivative work version of both an earlier broadcast and the original theater production); Mister B Textiles Inc. v. Woodcrest Fabrics, Inc., 523 F. Supp. 21 (S.D.N.Y. 1981) (fabric design derived from pictures of two other fabrics held to be a derivative work); see also Durham, supra note 21, at 857 ("A wide variety of unauthorized productions, based in some fashion on a copyrighted work, have been held to be derivative works, including not only obvious adaptations such as translations, abridgments, and dramatizations, but also more remote cousins of the original work, such as three-dimensional toys based on two-dimensional drawings, cassette tapes designed to function with a copyrighted talking teddy bear, and trivia books based on the television series Twin Peaks." (footnotes omitted)).

172. See, e.g., Greenberg, 244 F.3d at 1273-75; Lee, 125 F.3d at 581-83; Lewis Galoob Toys, Inc., 964 F.2d at 967-69; Mirage Editions, Inc., 856 F.2d at 1343-44; Sherry Mfg. Co. v. Towel King of Fla., Inc., 753 F.2d 1565, 1568-69 (11th Cir. 1985); Lone Ranger Television, Inc., 740 F.2d at 721-23; Midway Mfg. Co., 704 F.2d at 1013-14; L. Batlin \& Son, Inc., 536 F.2d at 492. See generally Goldstein, supra note 149 , at 210 ("Although the [Copyright] Act's commitment to derivative rights and derivative works is clear, judicial acceptance has been uneven."). Among the chief points of contention are the following: whether there is some quantitative minimum of the original work that must be present in the unauthorized work, Micro Star, 154 F.3d at 1111-12, whether the variation to the work must reflect a minimum level of originality, Mirage Editions, 856 F.2d at 1343-44, and/or whether the resulting work must be fixed in a tangible form. Lewis Galoob Toys, 964 F.2d at 967; Dun \& Bradstreet Software Servs., Inc. v. Grace Consulting, Inc., 307 F.3d 197, 210 (3d Cir. 2002)); see also Tyler T. Ochoa, Copyright, Derivative Works and Fixation: Is Galoob a Mirage, or Does the Form(Gen) of the Alleged Derivative Work Matter?, 20 Santa Clara Computer \& High Tech. L.J. 991, 1001 (2004) ("[I]f fixation is not required, [as a prerequisite to eligibility for derivation work status] that means that the preparation of any unfixed derivative work, even only in one's own mind, would be a prima facie infringement of the copyright in the underlying work."). See generally Nicolas, supra note 26, at 1 (discussing judicial construction of the derivative work right in connection with add-on software).

173. See Goldstein, supra note 149, at 215-16 ("The English and American history reflects both a growing commitment to derivative rights and a clear sense that the proper measure for their infringement will often nec essarily differ from the measure employed in cases involving the narrower reproduction right. Yet virtually none of these decisions has drawn a principled line capable of separating derivative rights from reproduction rights, and only a few have systematically addressed the distinction's full implications ...." (footnote omitted)); see also 2 Nimmer \& Nimmer, supra note 2, § 8.09[A], at 9-142.14 to -142.19.

174. See, e.g., Stowe v. Thomas, 23 F. Cas. 201 (C.C.E.D. Pa. 1853) (No. 13,514).

175. See, e.g., Nichols v. Universal Pictures Corp., 45 F.2d 119, 121 (2d Cir. 1930) ("It is of course essential to any protection of literary property, whether at common-law or under the statute, that the right cannot be limited literally to the text, else a plagiarist would escape by immaterial variations."); Durham, supra note 21 , at 858 ("[C]opyright protects against more than verbatim reproduction; an author's 
unauthorized use of protected expression in a subsequent work also constitutes a violation of the derivative work right, and such is the case whether or not there is any ordinary copying of the protected expression in connection with said use. ${ }^{176}$ Thus, the $u s e$ of protected expression is common to a violation of both rights, but the use must also constitute some form of copying to be considered a violation of the reproduction right. ${ }^{177}$ This overlap has made it difficult to distinguish between non-literal copying and the creation of a derivative work, and it is difficult to identify consistent characteristics for derivative works. This sometimes results in the characterization of a revised work as a derivative work when it would be better assessed as a non-literal copy, and vice versa.

This confusion (and the concomitant blurring of the derivative work right) might be minimized, however, if courts and commentators would keep in mind the principal infringement conduct each respective right is intended to preclude as a means for distinguishing between violations of the two rights. ${ }^{178}$

copyrightable expression is said to extend to a higher level of abstraction. In the case of a novel, copyright might confer rights to the characters and incidents, even against in fringers who choose different words to depict them. Hence, there is considerable overlap between the right to 'reproduce' the copyrighted work and the right to create derivative works. A motion picture based on a novel, including the same characters and the same plot developments, might be considered both an adaptation of the novel and, in a nonliteral sense, a copy or reproduction of the novel." (footnotes omitted)).

176. See H.R. REP. No. 94-1476, at 62 (1976), as reprinted in 1976 U.S.C.C.A.N. 5659, 5675 ("The exclusive right to prepare derivative works ... overlaps the exclusive right of reproduction to some extent. It is broader than that right, however, in the sense that reproduction requires fixation in copies or phonorecords, whereas the preparation of a derivative work, such as a ballet, pantomime, or improvised performance, may be an infringement even though nothing is ever fixed in tangible form."); see also Benny v. Loew's Inc., 239 F.2d 532, 537 (9th Cir. 1956) (a burlesque or parody of a serious work held both an "other version" and an infringing "copy"), aff' $d$, 356 U.S. 43 (1958); Macmillan Co. v. King, 223 F. 862 (D. Mass. 1914) (an abridgement or synopsis of plaintiff's work held both an "other version" and an infringing "copy"); Micro Star, 154 F.3d at 1112; Cohen, supra note 165, at 626-29, 632-33.

177. See supra text accompanying note 174 .

178. See id. Insofar as the courts are concerned, finding the fine distinction between overlapping exclusive rights is often of no practical significance to resolution of infringement litigation. For example, the Sixth Circuit in Bridgeport noted the failure of the district court in Grand Upright Music Ltd. v. Warner Bros. Records, Inc., 780 F. Supp. 182 (S.D.N.Y. 1991), one of the first sampling infringement cases, to indicate whether exclusive rights in both the subject musical composition and sound recording were infringed, and the court in Bridgeport only discussed the infringement of the musical composition. See Bridgeport Music, Inc. v. Dimension Films, 410 F.3d 793, 804 n.16 (6th Cir. 2005); see also Vault Corp. v. Quaid Software Ltd., 847 F.2d 255, 267-68 (5th Cir. 1988) (holding that unauthorized work was not a derivative work without deciding whether the unauthorized work constituted a section 117 adaptation). Thus, for example, whether the unauthorized addition of material to a protected work is ultimately considered a trivial variation (the creation of a non-literal copy) or creative interposition (the creation of a derivative work), the defendant is nonetheless liable for copyright infringement. "A single act of infringement may violate [multiple exclusive] rights at once, as where a publisher reproduces, adapts, and sells copies of a person's copyrighted work as part of a publishing venture.” H.R. REP. No. 94-1476, at 61. 
The reproduction right redresses misappropriation of primary or direct markets for the work by prohibiting the unauthorized copying of expressive elements. The derivative work right redresses misappropriation of indirect or potential markets for the work, as well as the usurpation of primary or direct markets, by prohibiting the unauthorized use of expressive elements in subsequent works, regardless of whether such use involves any "copying" in the ordinary sense of the term. ${ }^{179}$ However, inasmuch as use in the absence of (non-trivial or creative) variation is merely (literal or non-literal) copying, ${ }^{180}$ it would seem that some use and variation upon protected expression is the critical infringement conduct under the derivative work right. ${ }^{181}$

The reproduction and derivative work rights are therefore best regarded as providing for a connective spectrum of protection against the unauthorized exploitation of the expressive elements in a copyrighted work. ${ }^{182}$ At one end of the spectrum, the reproduction right precludes base copying; at the other end, the derivative work right guards against misappropriation in the absence of ordinary copying, such as that involved in an unauthorized translation. ${ }^{183}$ At the middle of the spectrum, however, the two rights converge and eventually overlap, depending upon the nature of the infringing conduct in

179. See, e.g., Lone Ranger Television, Inc. v. Program Radio Corp., 740 F.2d 718, 720-21 (9th Cir. 1984) (interpreting the 1909 Act as prohibiting remixing of Lone Ranger scripts for radio play without discussing substantial similarity); SAS Inst., Inc. v. S \& H Computer Sys., 605 F. Supp. 816, 830 (M.D. Tenn. 1985) (finding that "based upon" is broader than "substantially similar"). Thus, for example, where a novel is loosely adapted into a movie or its recognizable characters are used in another story without permission, the derivative work right is infringed despite the fact that there may be no reproduction of protected expression in the ordinary sense. See also Durham, supra note 21, at 858 ("In a few cases ... courts have seemed to find it sufficient to violate the right of adaptation if the defendant's work is derived, in some sense, from the plaintiff's, even though little or nothing of the original can still be perceived.").

180. See, e.g., Nichols, 45 F.2d at 121.

181. See, e.g., Montgomery v. Noga, 168 F.3d 1282, 1290 n.12 (11th Cir. 1999); Sherry Mfg. Co. v. Towel King of Fla., Inc., 753 F.2d 1565 (11th Cir. 1985); Lone Ranger Television, Inc., 740 F.2d at 720-21; Moore Publ'g, Inc. v. Big Sky Mktg., Inc., 756 F. Supp. 1371, 1374, 1378 (D. Idaho 1990); 1 Nimmer \& NimmER, supra note $2, \S 3.03$ [A], at 3-11 ("[I]n order to qualify for a separate copyright as a derivative or collective work, the additional matter injected in a prior work, or the manner of rearranging or otherwise transforming a prior work, must constitute more than a minimal contribution."); see also Ochoa, supra note 172, at 1019 ("[T] his history [of the development of the derivative work right] suggests that the principal purpose behind the right ... was to expand the scope of the reproduction and public performance rights to include adaptations and other new versions of copyrighted works." (emphasis omitted)).

182. See, e.g., Midway Mfg. Co. v. Artic Int'1, Inc., 704 F.2d 1009, 1013 (7th Cir. 1983); Gold STEIN, supra note $8, \S 1.4 .2$, at $1: 13$ ("As a general rule, the reproduction right leaves off and the derivative right begins at that point at which the contribution of independent expression to an existing work effectively creates a new work for a different market.").

183. See Stowe v. Thomas, 23 F. Cas. 201 (C.C.E.D. Pa. 1853) (No. 13,514); Nicolas, supra note 26 , at 4 . 
question. Judicial assessment of such "overlapping infringement" should focus upon the salient infringement activity in identifying violations of the exclusive rights.

For example, unauthorized reproduction combined with trivial changes to a copyrighted work should be redressed as non-literal infringement of the reproduction right. ${ }^{184}$ The "variations" in such cases are insignificant from a copyright perspective, ${ }^{185}$ and it is the unauthorized reproduction that constitutes the principal infringement conduct. ${ }^{186}$ Unauthorized reproduction combined with creative variation, ${ }^{187}$ however, shifts the infringement conduct

184. See, e.g., Dun \& Bradstreet Software Servs., Inc. v. Grace Consulting, Inc., 307 F.3d 197, 213-14 ("[Copying of source code] may not be justified on the ground that not all elements ... were copied or that there were some dissimilarities [between the copy and the original]. [The alleged infringer] may have rearranged some of the words in the plagiarizing program or altered or replaced one or more components in its program, but these efforts to distinguish its program from [the original] does not erase the literal copying of [the original] source code ....").

185. See L. Batlin \& Son, Inc. v. Snyder, 536 F.2d 486, 492 (2d Cir. 1976) ("To extend copyrightability to minuscule variations would simply put a weapon for harassment in the hands of mischievous copiers intent on appropriating and monopolizing public domain work."), cert. denied, 429 U.S. 857 (1976); Donald v. UARCO Bus. Forms, 478 F.2d 764, 766 (8th Cir. 1973) (changing language of form agreement from that of a sales contract to that of a service contract held a trivial variation); Caliga v. Inter Ocean Newspaper Co., 215 U.S. 182 (7th Cir. 1909); Towle Mfg. Co. v. Godinger Silver Art Co., 612 F. Supp. 986, 992 (S.D.N.Y. 1985) (obvious arrangement of pre-existing cutting designs on crystal baby bottle uncopyrightable); Grove Press, Inc. v. Collectors Publ'n, Inc., 264 F. Supp. 603, 605 (C.D. Cal. 1967) (changes consisting "almost entirely of elimination and addition of punctuation, changes of spelling of certain words, elimination and addition of quotation marks, and correction of typographical errors" held "trivial" and not copyrightable).

186. While it may be theoretically possible to separate uncreative variation from reproduction, it is difficult to conceive of an actual example. For instance, the use of recognizable characters or plot themes can be accomplished in the absence of ordinary copying, but it would seem that any such use would involve at least some minimal creativity within the meaning of the copyright law. Professor Durham expresses a similar point of view. See Durham, supra note 21, at 859 ("To require originality in an infringing work may seem perverse; what makes an infringing work objectionable is the extent to which the work is unoriginal. Nevertheless, because the second sentence of the statutory definition of 'derivative work' refers to 'an original work of authorship,' some have argued that even an infringing derivative work must exhibit some originality. ... Indeed, the standard for 'originality' is so low that it would be rare for any form in which a work might be recast to fail to be original. On those occasions, infringement could often be found in the right of duplication." (footnotes omitted) (emphasis omitted)); Goldstein, supra note 149, at 227.

187. The copyright law requires both independent creation and at least a spark of creativity as prerequisites to copyright protection. See 1 Nimmer \& Nimmer, supra note 2, § 2.01[A], at 2-9 ("Originality in the copyright sense means only that the work owes its origin to the author, i.e., is independently created, and not copied from other works. Therefore, a work is original and may command copyright protection, even if it is completely identical with a prior work, provided it was not copied from such prior work but is rather a product of the independent efforts of its author." (footnote omitted)); $i d$. $\S 1.08[\mathrm{C}][1]$, at 1-111 ("[A]lmost any ingenuity in selection, combination or expression, no matter how crude, humble or obvious, will be sufficient ....”); see also Feist Publ'ns, Inc. v. Rural Tel. Serv. Co., 499 U.S. 340, 348 (1991) ("Factual compilations . . may pos sess the requisite originality[, . . . [if the] choices 

into the derivative-work right portion of the protective spectrum. ${ }^{188}$ Because non-trivial and creative variation is the sole province of the derivative work right, and because the presence or absence of reproduction conduct is nonessential to infringement of this right, the resulting work is best approached as a derivative work. ${ }^{189}$

as to selection and arrangement ... are made independently by the compiler and entail a minimal degree of creativity."); Harper \& Row Publishers, Inc.v. Nation Enters., 471 U.S. 539, 547-549 (1985) (discussing the requirement of originality, even in a nonfiction work); L. Batlin \& Son, Inc., 536 F.2d at 490, 491-92 ("[T]here must be independent creation, but it need not be invention in the sense of striking uniqueness, ingeniousness, or novelty.”); Niels B. Schaumann, An Artist's Privilege, 15 CARdozo ArTs \& ENT. L.J. 249, 257-58 (1997) ("[P]resent-day conceptions of authorship imply both origination and creativity, wrapped in the appellation 'originality,' which in turn justifies the author's exclusive rights."). Where changes to a protected work reflect at least copyright creativity, the result is most properly evaluated as a derivative work whether or not the result is also independently copyrightable. While the work might also reflect intrusion upon the (non-literal) reproduction right, redress for the unauthorized but creative use of the expressive elements of a copyrighted work is the unique province of the derivative work right. Moreover, addressing such works as derivative works as opposed to non-literal copies will help to establish consistent elements for derivative works.

188. As indicated above, some courts have held that the variations to the work need not be original in order that the result be characterized as a derivative work. These courts draw a distinction between a copyrightable derivative work and an infringing derivative work. See, e.g., C Tek Software, Inc. v. New York State Bus. Venture P'ship (In re C Tek Software, Inc.), 127 B.R. 501, 506-07 (Bankr. D.N.H. 1995). Where the issue is merely whether the original work has been infringed, some courts have held that the variations to the expressive elements of the copyrighted work need not themselves be original as it seems contradictory to require originality in connection with an act of infringement. See, e.g., Mirage Editions, Inc. v. Albuquerque A.R.T. Co., 856 F.2d 1341 (9th Cir. 1989). What these cases overlook, however, is that the unauthorized creation of a derivative work is a very particular kind of infringement, one which anticipates that the infringer will indeed make some kind of creative contribution in connection with her unauthorized use of a copyrighted work. Nonetheless, just as unauthorized distribution violates the copyright holder's exclusive rights even if the works are handed out to the poor, the creative use of another's protected expression will violate the derivative work right whether or not the result is itself copyrightable. In the absence of creative variation, the infringer's conduct will fail to transcend the realm of reproduction and constitutes no more than base (literal) or substantial (non-literal) copying. Treating uncreative variation simply as non-literal copying places the emphasis on the salient infringement conduct; such acts are less "acts of variation" than they are acts of disguised reproduction. Thus, where the original work is left intact but for the unauthorized addition of creative material, the result violates both the reproduction right and the derivative work right. However, it is conceptually accurate (and less confusing) to evaluate the result as a derivative work. See Gold STEIN, supra note 8, § 8.5.2.1, at 8:94 to :95 ("Since a derivative work will characteristically recast the original work into a different form, it will rarely embody a literal replication of the underlying work. If a court abides by the letter of the law that has evolved in the reproduction right cases, it will probably find [reproduction] infringement in only the most unusual derivative rights case- for example, where the defendant abridges a copyrighted rule book by copying selected passages literally, rather than by paraphrasing and condensing the whole.").

189. Because detectable uncreative variation will always reflect some kind of literal or non-literal reproduction, there is no practical need to extend the derivative work right to such cases of "disguised" literal or non-literal reproduction. Thus, the derivative work right should be reserved to address unauthorized creative variation whether or not there is also some copying involved. Again, while splitting this conceptual hair may often be a distinction without a difference to copyright litigants (as either 
Moreover, where unauthorized variation passes the copyright threshold for creativity, the resulting work is more likely to pose a threat to indirect and potential markets for the original work. When such conduct is combined with literal reproduction, it may not only compete directly with the original work but may very well usurp the direct market for the original work altogether. Protecting against these kinds of encroachments upon the copyright holder's property incentives is in the raison d'etre of the derivative work right. ${ }^{190}$

Thus, whether the underlying work is a computer software program or a more traditional copyrighted work, a requirement that conduct which infringes the derivative work right must include some creative variation upon the work's protective elements illuminates the key distinction between the reproduction and derivative work rights. ${ }^{191}$ Moreover, specifically with respect to the proposed software derivative work right, a requirement of creative variation assures some minimal copyright benefit to society in

classification of a defendant's conduct mandates a finding of infringement), it would nonetheless serve the cause of clarity if courts would strive to rule upon these conceptual questions. See, e.g., Mtima, supra note 142 , at $449-52$.

190. See, e.g., Stowe v. Thomas, 23 F. Cas. 201, 207 (C.C.E.D. Pa. 1853) (No. 13,514) (“A 'copy’ of a book must, therefore, be a transcript of the language in which the conceptions of the author are clothed; of something printed and embodied in a tangible shape. The same conceptions clothed in another language cannot constitute the same composition, nor can it be called a transcript or 'copy' of the same 'book.' I have seen a literal translation of Burns' poems into French prose; but to call it a copy of the original, would be as ridiculous as the translation itself."); see also Goldstein, supra note 149, at 212 (discussing early English and American decisions which held that the addition of creative material to a copyright work precluded a finding of infringement of the reproduction right: "Although it might seem strange to excuse an admitted piracy on the ground that the pirate's treasure has independent as well as borrowed content, these early decisions properly recognized that the purpose of copyright is to encourage the production of new, original works, and that abridgements and translations are as important to their audiences as underlying works are to theirs.").

191. It is at this point, however, that the present analysis diverges slightly from the approach offered by Professor Goldstein. Whereas both approaches emphasize creative variation as the line of demarcation between violation of the reproduction right and the derivative work right, under Professor Goldstein's approach, the combination of creative material with "expressive elements from the original" would only be assessed under the derivative work right where the result serves a different market from that of the original work. Goldstein, supra note 149, at 217. However, Professor Goldstein acknowledges that this distinction does not always provide a bright dividing line. "Has an infringer who strings together excerpts from [a copyrighted] novel violated the reproduction right, the derivative right, or both? Although the infringer has added no expression of his own, he has contributed the arguably expressive effort of editing ... . Cases like these underscore the fact that the difference between the right to reproduce and the right to prepare derivative works will often be one of degree rather than kind and that, in these cases, the distinction is best resolved according to the comparative degree to which the infringing work belongs to one category rather than the other...." Id. at 217-18 n.29. In accord with Professor Goldstein, the present proposal would look to the primary infringement conduct to classify the result in such a case. If the result is a mere uncreative "cut and paste," it would be treated as a non-literal copy; if the editorial contributions reflect at least a spark of creativity, the result would be assessed as a derivative work. 
exchange for the wider latitude for unauthorized program modification. ${ }^{192}$ Society would, therefore, obtain some creative output as well as the utilitarian bounty of additional versions of a copyrighted program. ${ }^{193}$

The Scope of the Derivative Work Right: What Interests Does and Should the Right Protect?

Where a modified software program reflects creative variation upon protected expression in the underlying program, it should be regarded as a derivative work and therefore potentially infringing upon the derivative work rights and interests attendant to the original work. Accordingly, in shaping a derivative work right for software programs, it is important to identify the interests that the derivative work right is intended to preserve for the benefit of the copyright holder.

In general, the derivative work right reserves to the copyright holder the right to exploit indirect and subsequent commercial markets for her work through creative use of the expressive elements in her work in subsequent

192. One other observation regarding the exclusion of uncreative variation (i.e., non-literal copying) from the definition of derivative works is in order. While such non-literal copying is generally precluded by section 106, it may be permitted when it qualifies as engagement in the adaptation privilege (i.e., minor changes in connection with an "essential step utilization"). The anomalous result of prohibiting marketharmful creative variations under the proposed software derivative work right, but overlooking potentially market-harmful uncreative variations as adaptations, is avoided by resort to section 117(2) and the distribution prohibition, as discussed in Part III infra. In other words, where an adaptation does not rise to the level of a derivative work, and thus is not covered by the proposed software derivative work right and market impact rule, its market impact is nonetheless curtailed by the distribution prohibition in section $117(2)$.

193. Because the proposed software derivative work right would permit unauthorized, "marketinnocuous" derivative works, the proposed right might be used to argue that unauthorized trivial variation to the original program (i.e., non-literal copying) should be allowed where it did not harm the market for underlying work. This may well be another instance of a distinction with out a difference, in that non-literal copies usually pose a meaningful threat to the market for the original work and thus would be precluded under the proposed software derivative work right's prohibition against negative market impact. Nonetheless, in strengthening the analytical integrity of both the traditional derivative work right as well as the proposed software derivative work right, it is helpful to exclude uncreative (i.e., trivial) variation from the definition of a derivative work and to restrict such conduct to the definition of non-literal copying. Consequently, uncreative trivial variation would not fall within either the traditional or the proposed software derivative work right regardless of its market impact. Of course, unauthorized trivial variation might otherwise be allowed if it qualifies as a section 117 adaptation, which involves a slightly different analysis. Finally, as noted above, whether a derivative work must contain original creative variation is not the only point of contention regarding the requisite elements of a derivative work. Resolution of the debates regarding the requirements of fixation and/or the use of some minimum amount of the underlying work is left to more able commentators. 
works, and/or in alternative forms of expression. ${ }^{194}$ The derivative work right was initially developed with artistic works in mind to address the usurpation of indirect markets for such works by unauthorized translations, adaptations, and the like. ${ }^{195}$ These unauthorized versions were not covered by the reproduction right, because they were not literal reproductions of the original work. ${ }^{196}$ Thus, the need to preserve for the copyright holder the indirect

194. See generally Computer Assocs. Int'l, Inc. v. Altai, Inc., 982 F.2d 693, 701 (2d Cir. 1992) ("[C]opyright protection extends beyond a literary work's strictly textual form to its non-literal components.”); 2 GOLDSTEIN, supra note $8, \S 7.3 .1$, at 7:107 (“[M]otion pictures, translations and comic strips based on the novel will all infringe the derivative right because they add expressive elements and occupy markets different from the market occupied by the original."); Ochoa, supra note 172, at 1018-19; Goldstein, supra note 150, at 211 ("[T] he subsequent growth in legitimate theaters, motion pictures and television opened vast new markets for derivative uses impelling Congress to grant derivative rights to copyrighted works and to grant copyright protection to the derivative works created ....").

195. See Ochoa, supra note 172, at 1018-19 ("Under the 1790 and 1831 [Copyright] Acts, the copyright owner was given the exclusive right to 'print, reprint, publish, and vend' the work, and to prohibit the unauthorized importation of copies. Courts construed these rights narrowly; an unauthorized German translation of 'Uncle Tom's Cabin,' for example, was held not to be an infringement. In 1856, Congress added a right of public performance in dramatic compositions. In the 1870 general revision, Congress provided for the first time that 'authors may reserve the right to dramatize or translate their own works.' In 1897, the right of public performance was expanded to include musical works. Finally, in the 1901 Act, a broad derivative work right was created ...." (footnotes omitted)); Goldstein, supra note 150, at 214 ("Congress first granted derivative rights in the 1870 Copyright Act, providing that 'authors may reserve the right to dramatize or to translate their own works.' The right to abridge was not added until 1909 with the grant of the exclusive right to 'translate the copyrighted work into other languages or dialects, or make any other version thereof, if it be a literary work.' The 1909 Act also continued the right to dramatize a nondramatic work if it be a drama; to arrange or adapt it if it be a musical work; to complete, execute, and finish it if it be a model or a design for a work of art. The 1976 Act expanded and simplified the earlier formula, attaching the right to prepare derivative works to all forms of copyrighted works." (footnotes omitted)).

196. See Stowe v. Thomas, 23 F. Cas. 201, 207 (C.C.E.D. Pa. 1853) (No. 13,514) (“A ‘copy’ of a book must, therefore, be a transcript of the language in which the conceptions of the author are clothed; of something printed and embodied in a tangible shape. The same conceptions clothed in another language cannot constitute the same composition, nor can it be called a transcript or 'copy' of the same 'book.' I have seen a literal translation of Burns' poems into French prose; but to call it a copy of the original, would be as ridiculous as the translation itself."); see also Goldstein, supra note 149, at 211-12, 213 ("Early English copyright law defined copyright narrowly. The Statute of Anne gave authors and their assigns the exclusive right only to 'print, reprint or import' their books, and courts were slow to read this language as covering more than literal copies. ... American law ... generally followed the results and rationale of the English decisions." (footnote omitted)); see also Hannibal Travis, Building Universal Digital Libraries: An Agenda for Copyright Reform, 33 Pepp. L. Rev. 761, 814 (2006) ("At the time of the adoption of the Constitution and First Amendment, copyright law had no fair use doctrine, because it didn't need one.... [American copyright law] instead offered an 'expansive right of fair abridgement,' which provided readers and authors with the giddy freedom to republish copyrighted works in abridged, adapted, or translated form, or to use the works as fodder for their own creativity." (footnote omitted)). 
markets serviced by such derivative versions led to the adoption of an exclusive right that is not dependent upon ordinary reproduction conduct. ${ }^{197}$

Accordingly, while perhaps not the sole purpose of the derivative work right, ${ }^{198}$ a key objective underlying this exclusive right is the preservation of a work's expressive elements for further creative commercial exploitation by the copyright holder. ${ }^{199}$ Inasmuch as software programs are principally utilitarian works, however, the calculus for separating their protectable creative elements from those aspects that should remain freely available for use by the public is one necessarily different from that used in connection with aesthetic works. ${ }^{200}$ For functional works, copyright protection is typically

197. See, e.g., Goldstein, supra note 149 , at 209 (“Copyright, which once protected only against the production of substantially similar copies in the same medium as the copyrighted work, today protects against uses and media that often lie far a field from the original... Hardcover book sales, which once represented the principal measure of a novel's popular success, are today dwarfed by the income from motion pictures, television series, sequels, and merchandise derived from the novel."); Nicolas, supra note 26 , at 9 ("Section 106(2) ... extends the scope of protection granted to copyright owners . . beyond mere verbatim copying. [It] also provides copyright owners with an incentive to create more works and to create value-added variations of their protected works." (footnote omitted)).

198. See, e.g., 2 GoLD STEIN, supra note 8, $\$ 7.3$, at 7:101 ("Derivative rights also influence copyright owners' decisions on the kinds of works they will produce."); Ochoa, supra note 172, at 1006-07 (“[C]ommercial gain versus noncommercial use, does not affect whether a prima facie case of infringement [of the derivative work right] exists; rather, it is relevant (if at all) only to the fair use doctrine.... [Further, even where] the court [finds] that the copyright holder would not be deprived of current or expected revenue, the effect on the market is supposed to be relevant . . . only to the fair use doctrine." (footnote omitted)).

199. 2 Goldste IN, supra note $8, \S 7.3$, at 7:101 ("Derivative rights enable prospective copyright owners to proportion their investment to the returns they hope to receive not only from the market in which their work will first be published, but from other, derivative, markets as well.”); Durham, supra note 21, at 851 ("The expansion of exclusive rights allows authors to channel their efforts and investments toward works that may find much of their value in derivative markets. For example, a novelist assured of derivative rights might chose to write about gangsters rather than cowboys, reasoning that the motion picture rights for a gangster story would be more valuable." (footnote omitted)); see also Micro Star v. Formgen Inc., 154 F.3d 1107, 1112 (9th Cir. 1998) ("A copyright owner holds the right to create sequels ....").

200. See, e.g., Sega Enters. Ltd. v. Accolade, Inc., 977 F.2d 1510, 1524 (9th Cir. 1992) (“Computer programs pose unique problems for the application of the 'idea/expression distinction' that determines the extent of copyright protection. To the extent that there are many possible ways of ac complishing a given task or fulfilling a particularmarket demand, the programmer's choice of program structure and design may be highly creative and idiosyncratic. However, computer programs are, in essence, utilitarian articles - articles that accomplish tasks. As such, they contain many logical, structural, and visual display elements that are dictated by the function to be performed, by considerations of efficiency, or by external factors such as compatibility requirements and industry demands. . . In some circumstances, even the exact set of commands used by the programmer is deemed functional rather than creative for purposes of copyright" (citation omitted)). See generally Julie E. Cohen, Reverse Engineering and the Rise of Electronic Vigilantism: Intellectual Property Implications of "Lock-Out" Programs, 68 S. CAL. L. ReV. 1091, 1139-41 (1995) ("[A] programmer maybe efficient, in the sense of getting a task done, without being 
withheld from expression that embodies the methodology of the work, because protection for methods of operation and other utilitarian advancement is the province of the patent law. ${ }^{201}$ Thus, the functional nature of software programs plays an important role in identifying their protectable elements and, correspondingly, the corollary market interests that the derivative work and other exclusive rights are intended to preserve. ${ }^{202}$

at all creative, if the most efficient way [of undertaking a task is] standard within the industry."); Vetter, supra note 5, at 567 ("Software development is changing. The Internet allows far-flung development teams to collaboratively create software. Market forces demanding in teroperability and standardization enc ourage disclosure of traditionally concealed software elements, such as data structures, code, files, and other internal elements. Traditional intellectual property law — copyright, trade secret, and patent-has failed to keep pace." (footnotes omitted)). But see Schaumann, supra note 187, at 265 (arguing for the "marketimpact" approach in connection with unauthorized "appropriation art").

201. See 17 U.S.C. $§ 102$ (2006); Feist Publ'ns, Inc. v. Rural Tel. Serv. Co., 499 U.S. 340, 344-50 (1991); Baker v. Selden, 101 U.S. 99, 102 (1879); Sega Enters. Ltd., 977 F.2d at 1530; Apple Computer, Inc. v. Frank lin Computer Corp., 714 F.2d 1240, 1251 (3d Cir. 1983). See generally Stacey H. King, Are We Ready To Answer the Question?: Baker v. Sheldon, The Post-Feist Era, and Database Protections, 41 IDEA 65, 67 (2001) ("[T]here is a point at which works will not be afforded copyright protection, regardless of how much work or creativity has gone into their creation."); Seungwoo Son, Can Black Dot (Shrinkwrap) Licenses Override Federal Reverse Engineering Rights?: The Relationship Between Copyright, Contract, and Antitrust Laws, 6 Tul. J. Tech. \& InTell. Prop. 63, 74 (2004) ("Copyright protection does not extend to an idea itself, only the expression. Section 102(b) of the Copyright Act states: '[i]n no case does copyright protection for an original work of authorship extend to any idea, procedure, process, system, method of operation, concept, principle, or discovery, regardless of the form in which it is described, explained, illustrated, or embodied in such work.' The idea/expression dichotomy serves the primary purpose of copyright law, to promote creativity and disseminate useful arts, so that the public may benefit from the labor of authors." (footnotes omitted)); Leslie A. Kurtz, Digital Actors and Copyright-From the Polar Express to Simone, 21 Santa Clara Computer \& High Tech. L.J. 783 (2005); see also Ochoa, supra note 172, at 1007-08 ("[An important consideration is the] fundamental principle that a copyright protects only the expression of an idea, and not the idea, procedure, process, system or method of operation itself. If the rules of a [copyrighted] board game (or the 'behavior' of a video game) are considered part of the idea or method of operation, then [modifications] that alter only the unprotected idea or method of operation, rather than its expression (such as the appearance of the board game, or the artwork of the video game), should not be infringing." (footnote omitted)).

202. See Lexmark Int'l, Inc. v. Static Control Components, Inc., 387 F.3d 522, 537-42, 546 (6th Cir. 2004); Sony Computer Entm't, Inc. v. Connectix Corp., 203 F.3d 596, (9th Cir. 2000), cert. denied, 531 U.S. 871 (2000); Sega Enters. Ltd. v. Accolade, Inc., No. 92-15655, 1993 U.S. App. LEXIS 78, at *40-41 (9th Cir. Jan. 6, 1993); Computer Assocs. Int'1, Inc. v. Altai, Inc., 982 F.2d 693, 704 (2d Cir. 1992); Sega Enters. Ltd. v. Accolade, Inc., 977 F.2d 1510, 1524 (9th Cir. 1992); Mitchell L. Stoltz, Note, The Penguin Paradox: How the Scope of Derivative Works in Copyright Affects the Effectiveness of the GNU GPL, 85 B.U. L. REV. 1439, 1456-57 (2005) ("By 1992, courts began to recognize that traditional copyright analysis did not apply well to computer software. Although Congress has declared that computer programs are 'literary works' protected by copyright, programs also have many of the attributes of a machine or process, which traditionally have been protected by patent law. Because computer software is functional and utilitarian rather than purely expressive, courts began to formulate different copyright rules for software, often narrowing the scope of protection. Instead of comparing the 'total concept' of programs, for example, courts began to compare programs at multiple levels of abstraction, from the literal lines of program code 
Generally, protectable expression in a software program is found in its literal source and object code and sometimes in the structure and layout of the program. ${ }^{203}$ These aspects usually manifest the copyright holder's individual creative approach for using a computer to perform a particular function. Copyright protection is limited to this expression of the programmer's approach and does not extend to her idea to use a computer to undertake the designated task, or even to the individual method she devised for having a computer perform the subject task. ${ }^{204}$ Consequently, subsequent programmers are free to write their own programs to undertake the same function performed by the copyright holder's program and may even write programs that perform the function in the same manner as a preexisting program. ${ }^{205}$

Thus, the copyright holder's actual code and creative program structure are generally regarded as creative expression unavailable for unauthorized reuse by the general public. Nonetheless, there can be circumstances in which

to the overall structure and function of the program. Applying the principle that pure ideas are not protected by copyright, the courts began denying protection to specific features of programs that are purely functional, dictated by efficiency, or necessary for compatibility with other programs." (footnotes omitted)).

203. See, e.g., Dun \& Bradstreet Software Servs., Inc. v. Grace Consulting, Inc., 307 F.3d 197, 213-14 (3d Cir. 2002).

204. See § 102(b); Nichols v. Universal Pictures Corp., 45 F.2d 119, 121 (2d Cir. 1930); 4 Nimmer \& NimmER, supra note $2, \S 13.03[\mathrm{~F}][1]$, at 13-132 ("The broad purpose that the program serves, be it managing a dental laboratory, automating a factory, or dispensing cash at a bank teller machine, is an idea. Other elements of the program's structure and design, however, may also constitute ideas for copyright purposes." (emphasis omitted)); see also Meridian Project Sys., Inc. v. Hardin Constr. Co., 426 F. Supp. 2d 1101, 1112 (E.D. Cal. 2006) ("The idea/expression dichotomy serves to severely limit the scope of protection in fact-based works. 'Some ideas can be expressed in myriad ways, while others allow only a narrow range of expression.' Authors that convey facts in original works often can only choose from a narrow range of expression. Similarly, 'a subsequent author wishing to express the same facts will probably be required to use similar language. Therefore the scope of protection afforded factual works is thin." (citations omitted)); Goldstein, supra note 149, at 218 ("According to copyright gospel, infringement will be found only if defendant's work copies from plaintiff's, and only if the copying produces substantial similarities between the expression, and not just the underlying ideas, of the two works.").

205. See Feist Publ'ns, Inc. v. Rural Tel. Serv. Co., 499 U.S. 340, 345 ("Originality does not signify novelty; a work may be original even though it closely resembles other works so long as the similarity is fortuitous, not the result of copying."); see also Christopher Yoo, Copyright and Product Differentiation, 79 N.Y.U. L. REv. 212, 218 (2004) (“"T] he 'idea-expression dichotomy' limits copyright protection to the form of expression without offering any protection for the underlying ideas expressed in the work. This basic principle effectively guarantees that any competitor willing to undertake the same fixed-cost investment as the original author remains free to create alternative works with the same functional characteristics as any existing work." (citations omitted)); $c f$. Apple Computer, Inc. v. Franklin Computer Corp., 714 F.2d 1240, 1253 (3d Cir. 1983) ("If other programs can be written or created which perform the same function as [a copyrighted] program, then that program is an expression of the idea and hence copyrightable. In essence, this inquiry is no different than that made to determine whether the expression and idea have merged, which has been stated to occur where there are no or few other ways of expressing a particular idea."). 
considerations of efficiency may make it socially preferable that a subsequent programmer use some of the expressive elements of a preexisting program to create another program. ${ }^{206}$ In such cases, it would be inefficient and counterproductive (and socially undesirable) to require the later programmer to write an entirely new program. ${ }^{207}$

Take, for example, a hypothetical software program that assesses or regulates water temperature in a coffee brewing machine. The inventor of a new therapeutic muscle massaging device, which involves the application of heated liquids to the body, might wish to include a liquid temperature regulation program within her device. While she could have an original program written to perform this function, if regulating liquid temperature is a relatively minor aspect of her invention, the inventor might find it more efficient to adapt or incorporate the coffee maker's water temperature program for use in the new device. Such adaptation might significantly reduce the development period and costs and shorten the time in which the inventor is able to get a more affordable product to the public. If the adaptation of the preexisting program is not permitted, however, the inventor will have to incur the time and expense of creating an original liquid temperature regulation program, notwithstanding the fact that water temperature technology (as opposed to muscle therapy technology) is not her forte, and that there is already an adequate program in existence which would serve her limited needs. If the muscle massaging device will constitute a major advance upon the state of the art for muscle therapy equipment, from society's standpoint, it may be particularly wasteful to delay or increase the costs of its introduction

206. For example, Lemley \& O'Brien, supra note 7, cogently argue that duplication of code from scratch is generally an inefficient and socially unproductive enterprise:

Software reinvention unnecessarily incurs substantial costs by duplicating effort and failing to incorporate the lessons of past mistakes and inefficiencies into future software designs and implementations. These costs include both the direct costs of designing, coding, debugging, documenting, and supporting reinvented software, and the indirect costs associated with bugs and interoperability problems. Precise quantification of such costs is nearly impossible, but most experts agree that the aggregate costs are substantial. Rough estimates place the annual aggregate cost of reinvention at between $\$ 2$ billion and $\$ 100$ billion.

Id. at 260; see also Computer Assocs. Int'l, Inc. v. Altai, Inc., 982 F.2d 693, 707 (2d Cir. 1992) (holding that even where certain aspects of a software program's structure are creative, such aspects may not be protectable in accordance with the copyright doctrines of merger and scènes à faire).

207. See, e.g., Lemley \& O'Brien, supra note 7, at 260; Vetter, supra note 5, at 575 ("Collaborative necessity stems from the functional nature of software. Functional collaboration with components that must interoperate distinguishes most software from most authorship and artistic endeavor.”). 

in favor of the creation of a redundant liquid temperature regulation
program.

The issue of "reusing" creative elements of protected works in subsequent creative endeavor is addressed by both patent and copyright law but in very different ways. The patent law, which is specifically intended to promote utilitarian advancement for society's overall benefit, ${ }^{209}$ addresses the problem in at least two ways. First, a later inventor is allowed to "design around" a preexisting patent. ${ }^{210}$ This is because the patent protects only the specific method through which the protected invention performs its function, as articulated in the patent claims. ${ }^{211}$ Because other inventors are free to develop their own methods for performing the subject function, the "design around" inventor need only avoid specific and/or substantial duplication of the existing patent's rights. ${ }^{212}$

208. See, e.g., Mark A. Lemley, The Economics of Improvement in Intellectual Property Law, 75 Tex. L. Rev. 989, 1056-57 (1997) ("Improvements that produce positive externalities-that is, social benefits produced by a work that cannot be captured by the work's owner-may not be efficiently produced under a property rights licensing scheme. The willingness of an original copyright owner to license his work to an improver under a property rights scheme depends, not surprisingly, on the improver's willingness to pay. The improver's willingness to pay, in turn, depends (among other things) on the revenue the improver expects to receive from the improvement. Where the improver's expected revenue matches society's expected benefit, externalities do not interfere with efficient licensing between the parties. However, where the improver's work would create a significant social benefit that the improver cannot capture, the improver (and thus the original copyright owner) will undervalue that work. The result is that the improver may be unwilling or unable to pay for a license to use an original work, even though the aggregate benefit to society would more than make up for the license fee demanded."); LaFontaine, supra note 6, at 457-58 ("Over the past decade or so, a growing number of computer programmers, technology enthusiasts, and scholars have begun to question whether [the traditional] approach [to software development] is the best way to maximize the output and value of creative work. Restricting the ability to copy, modify, and distribute software may allow the copyright holder to extract the maximum amount of profit from their work, but that does not always guarantee the highest quality product. Recently there has been a great deal of interest and participation in collaborative soft ware development projects, characterized by wide distribution of code and freedom for users to copy, modify, and distribute it as they wish. This drive toward collaborative development is often referred to as the open source movement and the term F/OSS refers to programs developed under the open source banner." (footnotes omitted)).

209. See U.S. Const. art. I, § 8, cl. 8.

210. See 5B Chisum, supra note $12, \S 18.04$ [1][a][iii], at 18-589 ("The ability of the public successfully to design around [a patent] ... is one of the important public benefits that justify awarding the patent owner exclusive rights to his invention." (citation omitted)).

211. See 3 Chisum, supra note $12, \S 8.03$, at $8-18$.

212. Thus, under the patent doctrine of equivalents the second comer need only modify the preexisting invention such that it performs its function in a manner not proscribed by the patent claims. For example, in the coffee brewing hypothetical, if the water temperature regulator was a mechanical device that used a flotation ball to measure the reservoir water level (i.e., the lower the level the more water that had become steam) a later inventor might substitute a mercury thermometer for the flotation ball to gauge the overall temperature of the water compartment. See 5B CHIsUm, supra note 12, § 18.04, at 18-545. 
In addition to the "design around" option, subsequent inventors are also permitted to adapt patented inventions to entirely new applications. Again, because the patent only protects the specific claims of the patentee (i.e., my invention does " $X$ "), where the subsequent application is entirely novel (i.e., using the invention to do something the patentee never claimed her invention could do, that is, something entirely different from or unanticipated by " $X$ "), the later inventor not only avoids infringement liability, but she obtains her own "blocking" patent. ${ }^{213}$

Thus, variation upon a patented method of performance is a fertile frontier for other inventors, and the opportunity to commercially exploit any resulting achievements is dependent solely upon the inventors' practical and creative ingenuity. Such efforts are permitted, and even rewarded, where the resulting approaches meaningfully differ from the protected work (design around) or constitute novel achievements in their own right (blocking patents). ${ }^{214}$

Consequently, the protected market for a patented invention is effectively limited to the market for the inventor's embodiment of her invention. ${ }^{215}$ The

213. For example, where the first inventor develops a compound for use in curing leather, and the second inventor discovers a way to alter that compound towards use as a cure for some physical ailment, the latter inventor may receive her own patent for her discovery. See 1 Chisum, supra note $12, \S \S 1.03$ [8][b], at 1-348. While the second inventor cannot practice this new use of the compound without obtaining a license from the first inventor, the first inventor is "blocked" from putting her compound to this new use. See 5 Chisum, supra note $12, \S 16.02[1]$, at 16-9 to -10 (“'A] person may own a valid patent but be restrained from making, using or selling the invention by a valid 'blocking' patent of another or by the operation of state or federal laws."). Consequently, the first inventor has strong incentive to improve upon her invention, if she is capable of doing so, because if she chooses to rest on her laurels, she may forfeit certain new market monopolies to later inventors. Thus, later inventors have incentive to improve upon existing inventions, and prior patentees have incentive to license novel applications of their works, as refusing to do so will not preserve these opportunities for the original inventor; withholding a license would be detrimental to both inventors and society as a whole.

214. See Lemley, supra note 208, at 1069 ("Patent law seems better equipped than copyright law to deal with [the] real-world barriers to efficient licensing. The blocking patents and reverse doctrine of equivalents rules ameliorate licensing problems in complementary ways. The doctrine of blocking patents helps to overcome search problems by giving actual improvers a limited property right in their improvement, thus encouraging them to self-identify to original inventors. . . The reverse doctrine of equivalents also serves to counteract some of the holdup problems introduced by intellectual property rights which happen to confer market power. It does this by allowing a radical improver to use an original inventor's idea in certain circumstances in which the original inventor could otherwise have held the radical improvement hostage.").

215. 5B Chisum, supra note $12, \S 18.04$, at $18-73$ to -74 . For this and other reasons, Professor Lemley has argued in favor of patent protection for software "components" as a means by which to promote the reuse of software code. See Lemley \& O'Brien, supra note 7, at 294, 296 ("Patent law is more consistent with the development of a components market... . Because of their strength, patents eliminate a major problem with copyright protection: the incentive to reinvent software in order to appropriate the 
indirect markets that might exist for significant variations upon the original invention's methodology and/or for novel uses of the invention are not reserved to the patentee. ${ }^{216}$ Indeed, it can be reasonably argued that the patentee had no expectations regarding these markets, because she never envisioned entering them. ${ }^{217}$ As a result, the prospect of such markets and any profits therefrom were not a part of her incentive to invent. Moreover, if the first inventor lacks interest or expertise in areas relevant but tangential to her invention, society is not deprived of these advances because other inventors are free to pursue these possibilities.

In contrast to the patent law, the copyright derivative work right gives control over virtually all variations upon individual expression to the copyright holder. ${ }^{218}$ This is because, in the case of artistic works, there is little

ideas in the software component without infringing the original producer's copyright.... Finally, in some respects patent law provides initial developers with less control over others' derivative works than does copyright law. While improving a patented invention still requires a license from the owner of the original invention, substantial improvers can obtain theirown patents for their improvement. Substantial improvers may thus take advantage of the rule of 'blocking patents,' under which either party can prevent the other from using the improved invention unless the parties negotiate a license. The reverse doctrine of equivalents, which excuses literal patent infringement in certain cases of radical improvement, may also benefit some improvers. The additional bargaining power which these rules give the improver should encourage others to improve on prior inventions.... We therefore believe that a pure patent-based system is more conducive than a copyright-based system to the development of a market for reusable software components." (footnotes omitted)). As discussed below, a "market-impact" interpretation of the derivative work right would achieve similar results but would not be limited to programs that satisfied the requirements for patent protection.

216. Lemley, supra note 208, at 1070 ("The basic structure of the patent model is therefore quite simple. The treatment of improvements is a function of the value and significance of the improvement in relation to the original invention. Improvements which are minor in relation to the original invention are likely to be found to infringe, either literally or under the 'insubstantial differences' test for doctrine of equivalents infringement. More significant improvements within the range of the original claims still infringe the original patent, but in such cases the improver is entitled to a patent of his own. This not only encourages the development of significant improvements, but gives improvers bargaining leverage in licensing negotiations in direct proportion to the relative value of their improvements. Finally, truly radical improvements are exempted from liability to the original patent owner, regardless of whether they fall within the literal scope of the original claims, in order to encourage such improvements and to ensure that they reach the market." (footnote omitted)). Of course, many patentees attempt to avoid this limitation by articulating their claims as broadly as the law (or the patent examiner) will allow. See The Honorable Paul Michel, Judicial Constellations: Guiding Principles as Navigational Aids, 54 CASE W. Res. L. Rev. 757, 760 (2004) ("It may not be too cynical to suggest that patent prosecutors strive for the broadest coverage possible, while putting off other considerations until later. Narrower claims will almost always survive challenges, even if the broader claims do not. The doctrine of equivalents is also a background consideration. Ambiguous wording may create an elasticity in the claims. In general, there is a great deal of incentive to be deliberately broad, and even to be deliberately ambiguous.").

217. 5 Chisum, supra note $12, \S 16.03$, at $16-100$ to -185 .

218. See, e.g., Lemley, supra note 208, at 991-92 ("Patent and copyright law differ in how they treat improvements that fall within the scope of the original intellectual property right. Patent doctrines such as 
social benefit in permitting the substantial repetition of another author's creative expression of an idea, and the benefits of permitting the unauthorized interposition of a subsequent author's creative expression upon a previous author's work are outweighed by the accompanying author disincentives. ${ }^{219}$ The encouragement of individual expression while preserving underlying ideas for yet additional individual expression is the very point of American copyright law. ${ }^{220}$

For functional creative works, however, the continued availability of the subject function (the "idea" of the work) for further experimentation,

the rule of blocking patents and the reverse doctrine of equivalents offer some protection to the developers of significant or radical improvements. Improvers are therefore in a position to bargain with original patent owners to allocate the gains from their respective invention, and in some circumstances may even be free to use that invention without payment. By contrast, copyright doctrine currently offers little or no protection to improvers. Rather, the exclusive rights granted to the copyright owner in section 106 extend to cover any 'copy' or adaptation or alteration of the original that is nonetheless 'substantially similar' to the original work. So improvers - even radical improvers - have no power to bargain with copyright owners to divide the value of the improved work. If the work is substantially similar to the underlying copyrighted work, the original copyright owner has the right to exclude it from the market entirely." (footnotes omitted)); Stoltz, supra note 202, at 1453 ("Because unauthorized derivative works infringe the copyright in the original work, the owner of the original work gains effective control over copying and distribution of an unauthorized derivative. [For example] [s]oftware makers have invoked the derivative work right to prevent others from linking modules to their software.... [The GNU General Public License] purports to restrict which modules can be linked with GPL-covered programs by asserting the copyright holder's exclusive right to prepare derivative works." (footnotes omitted)). The copyright holder's ability to preclude the "reuse" of her creative expression is to some extent limited by the copyright doctrines of merger and scènes à faire. See 4 Nimmer \& Nimmer, supra note 2, §§ 13.03[F][2]-[3], at 13-135 to -148.1. As discussed below, however, these mechanisms are insufficient to address the full range of issues presented by software programs as functional copyrighted works.

219. Although American copyright law has always eschewed a natural rights perspective, it nonetheless reflects a reverence for the concept of authorship as well as the right of an author to retain at least some limited dominion over her individual expression. See Harper \& Row, Publishers, Inc. v. Nation Enters., 471 U.S. 539, 552-55 (1985) (discussing the author's right to determine the timing and circumstances under which her work is first presented to the public). See generally Peter Jaszi, Toward a Theory of Copyright: The Metamorphoses of "Authorship," 1991 Duke L.J.455; Litman, supra note 47, at 965-67, 974. In recent years, the copyright law has been amended to embrace limited moral rights for authors. See Visual Artists Rights Act of 1990, Pub. L. No. 101-650, § 603, 104 Stat. 5089, 5128-33 (1990) (codified as amended in scattered sections of 17 U.S.C.); Koenigsberg, supra note 9 ("In addition to copyrights, the copyright law was amended effective June 1, 1991, to grant very limited additional rights to authors of certain types of works.... The moral rights are those of attribution ... and integrity (the right to prevent mutilation or distortion of the work which would prejudice the author's honor or reputation)."); Vetter, supra note 5, at 658-59. See generally Roberta Rosenthal Kwall, Copyright and the Moral Right: Is an American Marriage Possible?, 38 VAND. L. Rev. 1 (1985); Diane S. Ciolino, Moral Rights and Real Obligations: A Property-Law Framework for the Protection of Authors' Moral Rights, 69 Tul. L. Rev. 935 (1995); Roberta Rosenthal Kwall, The Attribution Right in the United States: Caught in the Crossfire between Copyright and Section 43(A), 77 WASH. L. Rev. 985, 987-88 (2002).

220. See U.S. Const., art. I, § 8, cl. 8; supra Part I. 
variation, development, and implementation is as important as protecting any specific method for performing, or for any individual expression of a method for performing, that function. ${ }^{221}$ Inasmuch as software programmers have complete dominion over derivative versions of their works, ${ }^{222}$ however, later programmers have little secular incentive to adapt existing programs to perform their functions in different ways or to perform similar or related functions, even where the original programmer has no inclination or ability to pursue these opportunities herself. ${ }^{223}$

221. See Lemley, supra note 208, at 989, 997 ("Creation does not occur in a vacuum. Rather, knowledge is cumulative - authors and inventors must necessarily build on what came before them. Indeed, if they did not do so, the societal costs in terms of reinvention would be enormous. Try to imagine building something as complex as a car, without using any ideas from anyone who came before you (including such things as the wheel, nuts and bolts, screws, glass, and the combustion engine). As countless economists have demonstrated, efficient creation of new works requires access to and use of old works. And since 'improvements' may in many cases dwarfthe original work in terms of their practical significance, dynamic market efficiency over different generations demands such access as well." (footnotes omitted)).

222. See 17 U.S.C. § 106(2); LaFontaine, supra note 6, at 456 ("Derivative [software] works can be created in two ways. The first (and more straightforward) way occurs when someone adds to or modifies an existing work. This scenario occurs all the time in computer programming. A developer might start with a piece of code which is useful for completing certain tasks, but which does not quite fulfill her needs, and add and subtract code until it does. The second method for creating derivative works is far more complex, and may be unique to the world of software. A completely original piece of code might be considered derivative if it interacts heavily with a pre-existing program, such as where one software module invokes the use of another. This commonly occurs in the context of software 'libraries,' which, although not freestanding executables themselves, contain subprograms and helper data that other programs can utilize. Depending on how a program invokes a copyrighted library, it might be considered a derivative work for the purposes of copyright law." (footnotes omitted)).

223. See Lemley \& O’Brien, supra note 7, at 291-92 (“[O]riginal software developers may use strong copyright protection to control data's migration path by forbidding transfer of the original program data to subsequent, improved programs. Original developers may be unwilling to freely license use of their data, especially to a company whose program might compete with theirs. .. This problem is compounded by the relatively harsh rules governing derivative works, which are 'recast, transformed, or adapted' versions of preexisting works. . . . Ultimately, the derivative works rule discourages software designers using purchased interface components from rewriting, debugging, and generally improving software, since such alterations can potentially create an infringing derivative work. It therefore impedes vertical interoperability in the software market."). Indeed, this "uneasy fit" of software programs in to the copyright regime actually results in an unintended expansion of the copyright holder's derivative work interests. See Campbell v. Acuff-Rose Music, Inc., 510 U.S. 569, 592 (1994) ("The market for potential derivative uses includes only those that creators of original works would in general develop or license others to develop."). The inadvertent expansion of software derivative right interests in turn undermines the copyright function. See, e.g., Schaumann, supra note 187, at 263-64 ("The creative incentive of copyright is not measured directly; instead, the economic impact of the use is used as a proxy. The impact of any use on copyright's economic incentive to create is directly proportional to the economic impact of that use; the greater the positive impact, the more creative incentive is provided, and the greater the adverse economic impact, the more harm is done to the economic incentive to create. Any unauthorized use undermines copyright only to the extent that it impairs the economic incentive to create: if a use does not harm the incentive to create, it will not diminish the public's access to works of authorship, and copyright's purposes are served by the 


\section{The Doctrines of Merger and Scènes à Faire}

There are, of course, some limitations to the copyright holder's right to prevent the reuse of creative elements of her work. While the derivative work right precludes the wholesale modification of copyrighted software programs, the copyright doctrines of merger and scènes à faire effectively provide for the unauthorized use of portions of protected works under certain circumstances. $^{224}$ In general, individual expression that is essential to the

additional increment of access that the use provides." (footnote omitted)).

224. See Meridian Project Sys., Inc. v. Hardin Constr. Co., 426 F. Supp. 2d 1101, 1112 (E.D. Cal. 2006) ("Although the manner in which facts are expressed is protected by copyright, the extent of protection may be narrowed by other limiting doctrines. ... The merger doctrine serves as one such limitation[,] ... [and] the limiting doctrine of scènes à faire is closely related ...." (citation omitted)); Morrissey v. Procter \& Gamble Co., 379 F.2d 675, 678-79 (1st Cir. 1967) ("When the uncopyrightable subject matter is very narrow, so that 'the topic necessarily requires,' if not only one form of expression, at best only a limited number, to permit copyrighting would mean that a party or parties, by copyrighting a mere handful of forms, could exhaust all possibilities of future use of the substance. In such circumstances it does not seem accurate to say that any particular form of expression comes from the subject matter. However, it is necessary to say that the subject matter would be appropriated by permitting the copyrighting of its expression." (citations omitted)); William A. Graham Co. v. Haughey, 430 F. Supp. 2d 458, 466 (E.D. Pa. 2006) ("Under the merger doctrine, if there are no or few other ways of expressing a particular idea, the expression will be found to have merged into the idea. ... [T] he Copyright Act does not protect ideas.... Thus, when the idea and the expression of the idea coincide, then the expression will not be protected in order to prevent creation of a monopoly on the underlying art." (internal quotes omitted) (citations omitted)); 1 GolDSTE IN, supra note $8, \S 2.3 .2$, at 2:34 ("Courts will withhold copyright even from a work's original expression in cases where the work's underlying idea can effectively be expressed in only one way. The reason usually given for this result is that the work's idea and expression 'merge,' making the work as a whole unprotectible."); 4 Nimmer \& Nimmer, supra note $2, \S 13.03$ [B][3], at 13-86 to -87 ("In some circumstances . . . there is a 'merger' of idea and expression, such that a given idea is inseparably tied to a particular expression. In such instances, rigorously protecting the expression would confer a monopoly over the idea itself, in contravention of the statutory command. To prevent that consequence, courts have invoked the merger doctrine. In other words, given the dilemma either of protecting original expression, even when that protection can be leveraged to grant an effective monopoly over the idea thus expressed, or of making the idea free to all with the concomitant result that the plaintiff loses effective copyright protection, even over the precise original expression used, copyright law chooses the latter course. Thus, one famous case held that a jewelry pin in the form of a jewel-encrusted bee was only capable of one particular form of 'expression.' More commonly, however, a variety of expressions are available to jewelry designers. Other applications of the merger doctrine range from candy cane to a label depicting fruit to computer software to the headings on a Washing Instructions Chart." (footnotes omitted)); see also Team Play, Inc. v. Boyer, 391 F. Supp. 2d 695, 698-99 (N.D. Ill. 2005) ("It is commonly said that the [copyright] protection afforded goes only to expression and not to ideas. By judicial gloss, 'scenes a faire' are unprotectable under the Act except in certain limited circumstances. The term 'scenes a faire' refers to 'incidents, characters or settings which are as a practical matter indispensable, or at least standard, in the treatment of a given topic."'); BLACK'S LAW DiCTIONARY 1372 (8th ed. 2004) (“Standard or general themes that are common to a wide variety of works and are therefore not copyrightable. Examples of scènes à faire 
expression of an idea, as well as individual expression that has become stock or standard, is not entitled to copyright protection and can be used without the permission of the copyright holder. Together, the doctrines of merger and scènes à faire prevent a single author from monopolizing an idea (as opposed to monopolizing her individual expression of that idea) where there are only a limited number of ways in which to express that idea or where certain expression is incidental to any meaningful depiction of that idea. ${ }^{225}$

In computer software cases, courts have had ample occasion to explore the doctrines of merger and scènes à faire, most often in the context of allegations of unauthorized non-literal copying of protected programs. ${ }^{226}$ In many of these cases, the alleged infringer has not copied any of the literal source or object code of a program but has instead duplicated the overall structure or layout of the program and/or the sequential steps through which the program performs its designated task. ${ }^{227}$ In some cases, a software

are obvious plot elements and character types.").

225. Thus, expressing the idea of a contest entry form requires the inclusion of questions asking for information that will enable identification of the entrant. If the first person to prepare a contest entry form could monopolize her expression of such questions, no one else could ever create their own form, because there are only a limited number of ways in which to ask for someone's name, address, etc. The expression of such questions is said to "merge" with the idea of a contest entry form. In the same vein, a saloon, a sheriff, and a climatic gunfight are all stock incidentals to expressing the idea of life in the Old West. Under the scènes à faire doctrine, no author can prevent another from duplicating such material in her work. See Nichols v. Universal Pictures Corp., 45 F.2d 119, 121-22 (2d Cir. 1930); see also Sega Enters. Ltd. v. Accolade, Inc., 977 F.2d 1510, 1524 n.7 (9th Cir. 1992) (holding that literal code that embodied the only means for activating a video game console is functional and therefore not protectible under the copyright law).

226. See, e.g., Dun \& Bradstreet Software Servs., Inc. v. Grace Consulting, Inc., 307 F.3d 197, 213-14 (3d Cir. 2002); Lotus Dev. Corp. v. Borland Int'1, Inc., 49 F.3d 807, 814-15 (1 st Cir. 1995); Gates Rubber Co. v. Bando Chem. Indus., Ltd., 9 F.3d 823, 834 (10th Cir. 1993); Computer Assocs. Int'1, Inc. v. Altai, Inc., 982 F.2d 693, 703 (2d Cir. 1992); Whelan Assocs. v. Jaslow Dental Lab., Inc., 797 F.2d 1222 (3d Cir. 1986); Vetter, supra note 5, at 589 n.69 ("With respect to nonliteral copying, what followed software's entry into the copyright regime was a period of uncertainty as the courts struggled to determine the scope of coverage for source code as a literary work. The essential question was whether and how traditional copyright doctrines for literary works applied to parse the protectable from the unprotectable elements of the source code. These doctrines included (1) the idea/expression dichotomy[;] . . (2) not extending coverage to public domain elements; and (3) scènes à faire, a doctrine stating that protection does not extend to stock characters and common contexts. Eventually, courts worked out realistic formulations of these doctrines for source code as a literary work."). See generally Lateef Mtima, Protecting Non-Literal Elements of Computer Programs: Comparing the Approaches of Whelan and Altai (A.L.I.-A.B.A. Course of Study, Mar. 5, 1998) WL SC71 ALI-ABA 133 (reconciling the Whelan and Altai tests).

227. Although copyright protection precludes the non-literal reproduction of a software program, identifying protectable non-literal expression in such works can be difficult. The most widely used test for determining whether a subsequent program constitutes non-literal infringement of a prior program is that set forth in Computer Associates International, Inc. v. Altai, Inc., 982 F.2d 693 (2d Cir. 1992), commonly 
program's overall structure reflects creative expression, much the same as the way in which the overall plot of a novel can be just as expressive as its specific dialogue. In other cases, the structure of a program may not be creative at all, but rather follows a certain sequence or layout as a matter of practical necessity. For example, in a software program for scrambling eggs, the decision to place the step of breaking the eggshell at the beginning of the program probably does not reflect any individual creativity. ${ }^{228}$

In many software non-literal infringement disputes, courts have used the merger and scènes à faire doctrines to exclude portions of an individual software program from copyright protection. ${ }^{22}$ In these cases, courts have

referred to as "abstraction, filtration and comparison," or the Altai test. In applying the Altai test, a computer program is broken down into six levels of declining abstraction: the main purpose of the program; the program structure or architecture; the program modules; algorithms and data structures; source code; and object code. Unprotectable material, such as basic ideas, unoriginal material, etc., is "filtered out" by the court at each level, and then the remaining expressions from the two programs are compared to determine whether the later work incorporates some protectable, albeit non-literal aspect of the original work. See also Gates Rubber Co., 9 F.3d at 834 ("First, in order to provide a framework for analysis, we conclude that a court should dissect the program according to its varying levels of generality as provided in the abstractions test. Second, poised with this framework, the court should examine each level of abstraction in order to filter out elements of the program, which are unprotectable. Filtration should eliminate from comparison the unprotectable elements of ideas, processes, facts, public domain information, merger material, scènes à faire material, and other unprotectable elements suggested by the particular facts of the program under examination. Third, the court should then compare the remaining protectable elements with the allegedly infringing program to determine whether the defendants have misappropriated substantial elements of the plaintiff's program.").

228. Lotus Dev. Corp., 49 F.3d at 814 ("[W]hen faced with nonliteral-copying cases, courts must determine whether similarities are due merely to the fact that the two works share the same underlying idea or whether they instead indicate that the second author copied the first author's expression."); Computer Assocs. Int'l, Inc., 982 F.2d at 709-10 ("Profess or Nimmer points out that 'in many instances it is virtually impossible to write a program to perform particular functions in a specific computing environment without employing standard techniques.' . . . This is a result of the fact that a programmer's freedom of design choice is often circumscribed by extrinsic considerations such as (1) the mechanical specifications of the computer on which a particular program is intended to run; (2) compatibility requirements of other programs with which a program is designed to operate in conjunction; (3) computer manufacturers' design standards; (4) demands of the industry being serviced; and (5) widely accepted programming practices within the computer industry." (citation omitted)).

229. See supra note 224; see also Lexmark Int'1, Inc. v. Static Control Components, Inc., 387 F.3d 522, 537-42 (6th Cir. 2004); Dun \& Bradstreet Software Servs., 307 F.3d at 214 ("[Under] the doctrine of externalities, often referred to in a non-computer literary setting as scènes à faire[,] . . copyright protection is denied 'to those expressions that are standard, stock, or common to a particular topic or that necessarily follow from a common theme or setting.' .. . [F]or these reasons certain content of [an] allegedly infringed program that might have been dictated by external factors may not be subject to copyright protection.”(citations omitted)); Computer Assocs. Int'l, Inc., 982 F.2d at 708 (““[W] hen specific instructions, even though previously copyrighted, are the only and essential means of accomplishing a given task, their later use by another will not amount to infringement. "'); i-Systems, Inc. v. Softwares, Inc., No. Civ. 02-1951 (JRT/FLN) 2004 WL 742082, at*10 (D. Minn. Mar. 29, 2004); Lotus Dev. Corp. v. Borland 
found various aspects of the program to be dictated by practical necessity, industry interoperability standards, and similar "uncreative" decision making. ${ }^{230}$ Thus, the doctrines of merger and scènes à faire can be used to provide the public with access to certain functional, albeit creatively expressed, portions of copyrighted software programs. ${ }^{231}$

Unfortunately, the analytical limits of the merger and scènes à faire doctrines render them insufficient to provide public access to all "functionalalbeit-expressive" aspects of copyrighted software programs. To begin with, some courts have noted that the leading "structural infringement" cases, such as Whelan, Altai, and others, are inapposite to "inexact copying" disputes, which involve partial duplication of literal code. ${ }^{232}$ Thus, the merger and

Int'l, Inc., 799 F. Supp. 203, 210 (D. Mass. 1992) (tying merger to the question whether a "reasonable jury could find that the menu command hierarchy [created by Lotus and copied by Borland] was limited to one or even several alternate designs at the time it was created").

230. See, e.g., Sega Enters. Ltd., 977 F.2d at 1524 ("To the extent that a work is functional or factual, it may be copied."); Brown Bag Software v. Symantec Corp., 960 F.2d 1465, 1473 (9th Cir. 1992) (affirming district court's finding that "plaintiffs may not claim copyright protection of an ... expression that is, if not standard, then commonplace in the computer software industry"); Control Data Sys. v. Infoware, Inc., 903 F. Supp. 1316, 1323 (D. Minn. 1995) ("The court removes from consideration any elements of the program that constitute 'ideas' rather than expression, facts, processes, and any elements that are unoriginal or in the public domain."); Lexmark, Int'l, Inc., 387 F.3d at 536 (“As 'an industry-wide goal,' programming 'efficiency' represents an external constraint that figures prominently in the copyrightability of computer programs."); Computer Assocs. Int'l, Inc., 982 F.2d at 708; Secure Servs. Tech., Inc. v. Time \& Space Processing, Inc., 722 F. Supp. 1354, 1362-63 (E.D. Va. 1989).

231. See Control Data Sys., Inc., 903 F. Supp. at 1323 ("The levels of the program that are most abstract, such as the main purpose of the program, are unprotectable ideas. 'At the other end of the spectrum, source and object code, which are the literal elements of a program, will almost always be found to be protectable expression unless the doctrines of merger and scènes à faire come into play.' The merger doctrine denies copyright protection to any 'expression that is inseparable from or merged with the ideas, processes, or discoveries underlying the expression.' The purpose of the merger doctrine is 'to ensure that courts do not unwittingly grant protection to any idea by granting exclusive rights to the only, or one of only a few, means of expressing that idea.' The scènes à faire doctrine prevents a programmer from obtaining a copyright to 'expressions that are standard, stock, or common to a particular topic or that necessarily follow from a common theme or setting.' The doctrine also denies protection to expressions that are dictated by external factors. Examples of external factors are hardware standards and mechanical specifications, software standards and compatibility requirements, computer manufacturer design standards, target industry practices and demands, and computer industry programming practices."(citations omitted)); see also Meridian Project Sys., Inc. v. Hardin Constr. Co., 426 F. Supp. 2d 1101, 1112-13 (E.D. Cal. 2006), and cases cited therein.

232. See, e.g., Lexmark Int'1, Inc. v. Static Control Components, Inc., 253 F. Supp. 2d 943, 965 (E.D. Ky. 2003) ("As other federal courts have determined, the abstraction-filtration-comparison ... test is either unnecessary or simply does not apply in cases of literal copying."), rev'd on other grounds, 387 F.3d 522 (6th Cir. 2004); see also MiTek Holdings, Inc. v. Arce Eng'g Co., 89 F.3d 1548, 1555 n.16 (11th Cir. 1996) ("[The AFC test] was designed to help assess nonliteral copying of a nonliteral element, not nonliteral copying of computer code (a literal element).”); Lotus Dev. Corp. v. Borland Int'l, Inc., 49 F.3d 807, 815 (1st Cir. 1995) ("While the $[\mathrm{AFC}]$ test may provide a useful framework for assessing the alleged nonliteral 
scènes à faire analyses of these "structural infringement" cases are of limited value in deciding unauthorized derivative work disputes which involve the reuse or "inexact copying" of literal portions of a software program. ${ }^{233}$

Indeed, there are significant obstacles to raising the merger and scènes $\grave{a}$ faire doctrines in defense of the "reuse" of the literal elements of a software program in creating a subsequent program. So far as the merger doctrine is concerned, the later programmer must demonstrate that there are only a limited number of ways in which to express the subject method for performing the desired function as a software program, or that the original program represents the only efficient expression of the method in program code. ${ }^{234}$ Under the scènes à faire doctrine, the subsequent programmer must show that the original program is stock, standard, and/or dictated by standards in the industry. ${ }^{235}$ However, this issue is evaluated from the perspective of the

copying of computer code, we find it to be of little help in assessing whether the literal copying of a menu command hierarchy constitutes copyright infringement."); ILOG, Inc. v. Bell Logic, LLC, 181 F. Supp. 2d 3, 7 (D. Mass. 2002) (holding that literal copying is not governed by the AFC test); Data Gen. Corp. v. Grumman Sys. Support Corp., 803 F. Supp. 487, 490-91 (D. Mass. 1992) ("The complex [AFC] test ... and such a detailed code examination are not applicable to the case before this court. . . Since [the accused infringer] has directly copied [the copyright holder's object code], there is no need to confront the more difficult issue of evaluating 'non-literal' elements of a program."), aff'd, 36 F.3d 1147 (1 st Cir. 1994). Thus, the application of the doctrines of merger and scènes à faire in non-literal infringement cases is of limited value in the assessment of literal infringement claims, such as would be involved in the use and modification of a program's source code in the creation of a new program.

233. See supra note 228.

234. See, e.g., Apple Computer, Inc. v. Franklin Computer Corp., 714 F.2d 1240, 1253 (3d Cir. 1983) ("[Defendant] claims that whether or not the programs can be rewritten, there are a limited 'number of ways to arrange operating systems to enable a computer to run the vast body of Apple-compatible software.' This claim has no pertinence to either the idea/expression dichotomy or merger. The idea which may merge with the expression, thus making the copyright unavailable, is the idea which is the subject of the expression. The idea of one of the operating system programs is, for example, how to translate source code into object code. If other methods of expressing that idea are not foreclosed as a practical matter, then there is no merger. Franklin may wish to achieve total compatibility with independently developed application programs written for the Apple II, but that is a commercial and competitive objective which does not enter into the somewhat metaphysical issue of whether particular ideas and expressions have merged." (citation omitted)), cert. dismissed, 464 U.S. 1033 (1984); see also Computer Assocs. Int'1, Inc. v. Altai, Inc., 982 F.2d 693, 708 (2d Cir. 1992) ("It follows that in order to determine whether the merger doctrine precludes copyright protection to an aspect of a program's structure[,] . . . a court must inquire 'whether the use of this particular set of modules is necessary efficiently to implement that part of the program's process' being implemented.").

235. 2 Gold STEIN, supra note $8, \S 10.1$, at 10:5 (“[S]cènes à faire, in which a series of incidents and reactions are dictated by the nature of the situation being depicted, also belong to the common pool."); see also Lexmark Int'1, Inc. v. Static Control Components, Inc., 387 F.3d 522, 535 (6th Cir. 2004) ("[W]hen external factors constrain the choice of expressive vehicle, the doctrine of 'scenes a faire'- 'scenes,' in other words, 'that must be done'- precludes copyright protection."). See generally Lexmark Int'l, 387 F.3d at 535 ("In the computer-software context, the doctrine means that the elements of a program dictated by 
original programmer and not that of the subsequent programmer, and thus the operative question is whether the program would have been considered stock or standard when it was created, as opposed to whether it has since become a standard in the industry. ${ }^{236}$

Finally, neither doctrine adequately addresses the issue of adapting the original program for entirely new applications, such as in the coffee brewing and muscle massager hypothetical above. As discussed above, the existing water temperature program might constitute the most efficient means for generic performance of that function as part of a more complex device which undertakes a different overall task. While there may be alternative ways in which to express this function as program code and, moreover, alter the original literal code with regard to improving its use in coffee brewing, such variations and improvements may be entirely irrelevant to the advancement of massage therapy technology. Nonetheless, subsequent use of creative expression from a copyrighted program implicates the derivative work right, and the fact that such use involves an entirely new application for the underlying work is no defense to an allegation of infringement. ${ }^{237}$

practical realities-e.g., by hardware standards and mechanical specifications, software standards and compatibility requirements, computer manufacturer design standards, target industry practices, and standard computer programming practices-may not obtain protection."); 4 NIMMER \& NIMMER, supra note 2, $\S 13.03[\mathrm{~B}][4]$ ("[The doctrine] refers to "incidents, characters or settings which are as a practical matter indispensable, or at least standard, in the treatment of a given topic[,]' . . [ [and it] is often invoked to immunize from liability similarity of incidents or plot that necessarily follows from a common theme or setting." (footnote omitted)).

236. See, e.g., Dun \& Bradstreet Software Servs., Inc. v. Grace Consulting, Inc., 307 F.3d 197, 215 (3d Cir. 2002) ("[ [ ]n determining aspects of the program not entitled to protection because of external factors, we examine the program from the viewpoint of the creator. . . [T] circumstances and the external factors surrounding the author of the infringed program." (citation omitted)); see also Mitel, Inc. v. Iqtel, Inc., 124 F.3d 1366, 1375 (10th Cir. 1997); Computer Assocs. Int'l, Inc., 982 F.2d at 714; Control Data Sys. Inc., 903 F. Supp. at 1323 ("The question to be examined is whether external factors limited the choices available to the [original] programmers, not whether external factors may somehow limit the choices of [the subsequent] programmers."). Thus, in some cases, in evaluating the issue of interoperability, the court may be precluded from giving adequate weight to the impact of subsequent and continuing developments in the field.

237. As Professor Lemley has observed, while there is always the option of raising the defense of fair use in connection with such software "reuse," the viability of the fair use doctrine in these cases is questionable:

First, a critical factor in fair use analysis is the market impact of the use on the copyright owner. The Supreme Court has described this impact as "undoubtedly the single most important element of fair use," and Melville Nimmer has gone so far as to say that it is determinative. The Supreme Court has indicated that 'fair use, when properly applied, is limited to copying by others which does not materially impair the marketability of the work which is copied.' And the courts have further made it clear that this market impact includes not just the potential for lost sales of the original work, but also potential losses in the markets for derivative works and licensing fees. This emphasis 
In short, insofar as software programs are concerned, the traditional derivative work right inadvertently allows the first programmer to monopolize a program's function, short of another programmer's creation of an entirely new expression of that function. ${ }^{238}$ Because efficiency and utilitarian efficacy are considerations estranged from the copyright law, insufficient emphasis is placed upon the need for incremental improvement upon a program's function through the modification of the creative expression in which it is first embodied. $^{239}$ Moreover, because the derivative work right's reservation of

on market harm to the original copyright owner seems to preclude the possibility that a radical improvement which competes with the original work, or even with actual or potential licensed derivatives of that work, can nonetheless be a fair use.

Lemley, supra note 208, at 1024-25 (footnotes omitted). As discussed infra, to the extent that market impact is regarded as the predominant fair use factor, the proposed software derivative work right and concomitant public derivative work privilege will produce results consistent with fair use, albeit more expeditiously, in that the proposed software derivative work right consists of, at best, a two factor test. At the same time, however, fair use would remain a viable alternative in those cases in which moderate market impact is offset by favorable assessments under the remaining fair use factors.

238. See Reger, supra note 2, at 233 ("[C] ]urrent copyright deposit provisions sacrifice efficiency and experience by demanding reinvention rather than reuse. In other words, a programmer will write, expand, modify and finally develop an efficient code that enables a basic program to function in a certain way. Another company can not use this basic code and build upon it, but rather must reinvent another way to accomplish the same function."); Samuelson et al., supra note 10, at 2322-23 ("Typically, a programmer writes every line of code afresh, no matter how large the program is, or how common its tasks. To perceive the impact of this lack of standard building blocks, imagine trying to design an entire car in complete detail, down to the last fastener, without being able to assume the existence of any standard parts at all (not even nuts, bolts, or screws). With programs, every individual part has to be designed from scratch, and all of their design elements must be tested under a variety of conditions to be sure they work. This is one reason why programs are often so complex and their design so difficult." (footnotes omitted)). This is typical of the problems resulting from the unique nature of software programs as copyrightable works. See, e.g., Sega Enters. Ltd. v. Accolade, Inc., 977 F.2d 1510, 1526 (9th Cir. 1992) ("In summary, the record clearly establishes that disassembly of the object code in Sega's video game cartridges was necessary in order to understand the functional requirements for Genesis compatibility. The interface procedures for the Genesis console are distributed for public use only in object code form, and are not visible to the user during operation of the video game program. Because object code cannot be read by humans, it must be disassembled, either by hand or by machine. Disassembly of object code necessarily entails copying. Those facts dictate our analysis of the second statutory fair use factor. If disassembly of copyrighted object code is per se an unfair use, the owner of the copyright gains a de facto monopoly over the functional aspects of his work - aspects that were expressly denied copyright protection by Congress.").

239. See, e.g., Lotus Dev. Corp. v. Borland Int'1, Inc., 49 F.3d 807, 819 (1st Cir. 1995) (Boudin, J., concurring) ("Most of the law of copyright and the 'tools' of analysis have developed in the context of literary works such as novels, plays, and films. In this milieu, the principal problem-simply stated, if difficult to resolve - is to stimulate creative expression without unduly limiting access by others to the broader themes and concepts deployed by the author. ... The problem presented by computer programs is fundamentally different in one respect. The computer program is a means for causing something to happen; it has a mechanical utility, an instrumental role, in accomplishing the world's work. Granting protection, in other words, can have some of the consequences of patent protection in limiting other people's ability to perform a task in the most efficient manner. Utility does not bar copyright (dictionaries 
indirect markets was developed with artistic - as opposed to utilitarian or functional—works in mind, the inadvertent monopoly extends to commercial markets for entirely new applications of copyrighted programs, even where the copyright holder lacks concrete expectations or interests in such markets or, for that matter, any ability to satisfy them. ${ }^{240}$

Some software programmers and legal commentators have attempted to address this and other shortfalls in the extension of copyright protection to software programs through the advent of the open source movement. ${ }^{241}$ Open

may be copyrighted), but it alters the calculus."); Samuelson et al., supra note 10, at 2330-31 ("Innovation in software development is typically incremental. Programmers commonly adopt software design element-ideas about how to do particular things in software - by looking around for examples or remembering what worked in other programs. These elements are sometimes adopted wholesale, but often they are adapted to a new context or set of tasks. In this way, programmers both contribute to and benefit from a cumulative innovation process." (footnotes omitted)); Lemley \& O'Brien, supra note 7, at 256-57 ("Software developers routinely reinvent the software equivalents of the wheel and the transistor every time they develop a new program. By contrast, more traditional scientific and engineering disciplines, such as mechanical and electrical engineering, build upon existing components, structures, and methods with attributes and limitations widely known within these fields. These components, structures, and methods are incrementally improved, reused, and improved again in a constant cycle of innovation. As a result, a robust market exists for components such as gears, transistors, and standard cell semiconductor designs, whereas there is currently little, if any, market for software components. Many software cost and reliability problems stem from this software reinvention culture. In the words of one computer science professor, software development 'needs to become more of an engineering discipline.... It's treated too often as an art form ...." (footnotes omitted)). Where the original program is being adapted to an entirely new application, such as the hypothetical coffee brewing and water temperature program, the program might be approached as an efficient "standard" for incorporating liquid temperature regulation as a generic "subfunction" in programs and devices designed to perform entirely new tasks. Whereas improving upon the generic standard can provide social benefits, adapting it to provide a new functionality is also a socially desirable goal. See LaFontaine, supra note 6, at 455-56 ("Computer programs are a fertile ground for the creation of derivative works. Rather than writing a new program from scratch, it is often much easier to take existing code and modify it to provide new functionality. One need look no further than popular applications such as Adobe Acrobat (currently in its seventh incarnation) or the Microsoft Office suite of programs (eleventh) to see this process in action. In copyright terms, each is a derivative of the previous version." (footnote omitted)).

240. Lemley, supra note 208, at 1019 ("One thing that the derivative works right does do is make it clear that copyright law is intended to reach improvers as well as counterfeiters. The copyright owner's control over works in markets other than the one he entered is no accident, but part of the scheme of copyright protection."); Shubha Ghosh, How to Build a Commons: Is Intellectual Property Constrictive, Facilitating, or Irrelevant?, in Underst ANDING KNOWLEDGE AS a Commons: From Theory to Practice 209, 213 (Charlotte Hess \& Elinor Ostrom eds., 2006) ("While the grant of a patent or a copyright to an individual establishes only the right to exclude others from imitating the subject of the patent or copyright, exclusivity gives the intellectual property owner the legal ability to restrict entry into a field of endeavor and to deny access to knowledge.").

241. See Vetter, supra note 5, at 563; Reger, supra note 2, at 215; Natasha T. Horne, Open Source Software Licensing: Using Copyright Law to Encourage Free Use, 17 GA. St. U. L. REv. 863 (2001); Matthew D. Satchwell, The Tao of Open Source: Minimum Action for Maximum Gain, 20 Berkeley Tech. L.J. 1757 (2005); Klaus M. Schmidt \& Monika Schnitzer, Public Subsidies for Open Source? Some 
source, or "copyleft," essentially utilizes the exclusive rights mechanism of the copyright law to promote the unfettered development and adaptation of software programs. ${ }^{242}$ Programmers participating in open source permit the unrestrained adaptation of their programs in exchange for the user's promise that she will likewise permit the use and adaptation of the resulting derivative work toward the same ends. ${ }^{243}$

Perhaps unsurprisingly, however, there are many software program creators who are disinclined to participate in the open source movement. ${ }^{244}$

Economic Policy Issues of the Software Market, 16 HaRv. J.L. \& Tech. 473 (2003); David S. Evans \& Bernard J. Reddy, Government Preferences for Promoting Open-Source Software: A Solution in Search of a Problem, 9 Мich. Telecomm. \& Tech. L. Rev. 313 (2003); Andres Guadamuz Gonzalez, Open Science: Open Source Licenses in Scientific Research, 7 N.C. J.L. \& Tесн. 321, 323-24, 326-27 (2006); Stephen J. Davidson \& Gabriel Holloway, Protecting Trade Secrets in an Open Source Environment, in Open Source Software Spring 2006: Critical Issues in Today's Corporate Environment 143 (PLI Pats., Trademarks, and Literary Prop., Course Handbook Series No. 8821, 2006); see also Smith \& Mann, supra note 12, at 256 ("Software developers have responded to the demand for greater interoperability and product transparency in a variety of ways. First, many developers document and disclose essential interfaces and protocols so that independent developers and hardware manufacturers can easily write interoperable programs and hardware device drivers... . [S]ome developers also provide access to their programs' underlying source code and combine these with opportunities for licensing so that users and others can take advantage of these disclosures for their own purposes. In addition, firms across the IT industry regularly contribute to developing voluntary, industry wide technology standards.").

242. See LaFontaine, supra note 6, at 450-51 ("Recently, . . . another [distribution] model . . development known as the 'free/open-source software' (F/OSS) movement has emerged to challenge the dominance of the proprietary model. This new model turns traditional notions of limited access on its head by inviting interested programmers from all over the world to freely copy, share, and modify each other's work. Thanks in no small part to the advent of the Internet, numerous projects have sprung up to develop F/OSS applications, often with the express purpose of competing with their commercially developed counterparts. Anyone may volunteer to participate in these projects in whatever capacity they desire; those who make contributions to such projects are rarely paid for their services, and the resulting products may be freely used by anyone." (footnotes omitted)).

243. See, e.g., Vetter, supra note 5, at 590 ("[F]rom the moment [source] code is originally authored ... [copyright] protection attaches. The open-source approach leverages this protection to extend 'additional' control over the work. But the 'additional control imposes conditions that effectively ensure that the work is freely usable. This is the antithesis of traditional copyright-based licensing controls.... It uses the control of copyright to ensure that the collaborative aspects of the software persist: source code availability and royalty-free use." (footnote omitted)).

244. See, e.g., LaFontaine, supra note 6 , at 450 ("The copyright prong imposes a statutory prohibition on the copying, use, or modification of the work without the copyright holder's permission. The license prong is a contractual grant of that permission, subject to a set of restrictive terms designed to prevent the licensee from diluting the copyright holder's monopoly. By lifting copyright prohibitions in exchange for money, this arrangement ... allows the author to earn a profit from their creation, which in turn incentivizes them to produce new works. The proprietary model of copyright and restrictive license is particularly prevalent in the software industry: companies like Microsoft license their programs to end users for a fee, using the proceeds to pay for the development of the next version of 'Windows' or 'Office." (footnotes omitted)). Moreover, other commentators have proposed alternatives that would facilitate software modification while preserving software developers' traditional property rights, including the right to exploit 
Consequently, there is a need for mechanisms within the traditional copyright framework that will increase the availability of copyrighted software programs for adaptation and modification by the general public. ${ }^{245}$

The functional nature of software programs provides a substantive basis for special treatment of software derivative works, and section 117 provides statutory confirmation that such special treatment is consistent with Congressional intent. ${ }^{246}$ Software programs warrant special treatment with

and license their programs. See, e.g., Lemley \& O'Brien, supra note 7, at 255 (advocating patent protection for software components); Samuelson et al., supra note 10, at 2310.

245. As other commentators have noted, it is preferable to interpret and apply copyright protection for software in a manner so as to achieve the overarching goals of the copyright law. See Reger, supra note 2, at 216 ("[E]ven as early as the 1909 Copyright Act, the quid pro quo of federal copyright protection has been disclosure.... [D]isclosure promotes economic efficiency by building upon current works to create better, more efficient creations and processes. Society, in return, receives a creative work that stimulates and promotes future works of greater efficiency." (footnotes omitted)); Vetter, supra note 5, at $572 \mathrm{n} .22$ ("[S]oftware development is a creative activity that benefits from lessening the effective protection of the works, or preserving a realm of use for others, rather than successively endowing the work with controlenabling rights."). Rather than abandon the copyright regime, the proposed software derivative work right construes copyright protection in a manner that reconciles the objectives of the Copyright Act with software's unique characteristics as copyrightable works.

246. Other commentators have made cogent arguments in support of the "reuse" of copyrighted software. For example, Mark Lemley and David O'Brien have argued that more widespread software reuse, as opposed to software "reinvention" would improve program quality and reduce development costs. See Lemley \& O'Brien, supra note 7, at 265 (“[S]ystematic software reuse can improve the quality of components, increase the productivity of the creators, and reduce the time to market of the finished product. It is well known that the quality of code improves over time as bugs in a program are identified and fixed. Reuse facilitates this quality improvement because each piece of code is used over the life of several applications. Further, computer companies have a greater incentive to catch and remove defects in reusable components, where the cost of debugging is spread over a longer lifetime, than in software that is used once and thrown away." (footnote omitted)). Indeed, the authors have argued that software code should be developed with the intention that it be reused, not only by the copyright holder in subsequent projects, but by other developers as well:

Although they are difficult to quantify precisely, the private costs associated with the practice of software reinvention are substantial simply because so much code needs to be rewritten. A system that rewards reinvention rather than reuse also has substantial social costs. The social costs incurred by reinvention rather than include the indirect costs imposed by errors and bugs that go undetected after the implementation of a program. Software reinvention imposes indirect and consequential costs because newly created software modules exhibit much higher error rates than software components used multiple times. Some of these costs are predictable; the costs of identifying and correcting design and coding errors (bugs) appear privately as increased production costs and are passed on to the public as higher prices. Other costs are not predictable; latent, undiscovered bugs, and the delays associated with identifying and correcting such errors (debugging), can result in consequential losses. ...

Reinvention incurs these indirect and consequential costs each time programmers craft software from scratch. ... Although reused software is by no means bug-free, various studies have shown dramatic reductions in error rates for reused software compared with new code. An advantage of reused software is that bugs which are identified during prior use can be avoided or corrected in 
respect to the public's ability to modify them because, in passing section 117, Congress has said so. At the same time, however, judicial interpretation of section 117 confirms that the special treatment afforded in connection with the ordinary use and concomitant modification of software programs ceases when it results in the usurpation of the copyright holder's commercial market interests. ${ }^{247}$

If Congress determined that preservation of the copyright holder's commercial market interests is an appropriate countervailing consideration in ensuring optimal public use of software programs, it seems reasonable to conclude that that countervailing concern should also apply in assessing uses that engender additional works. In other words, just as the adaptation privilege is curtailed to preserve the copyright holder's market interests, the derivative work right should be similarly adjusted to accommodate the public interest in creative variation toward the development of additional software programs.

The proposed narrowing of the derivative work right, to preclude only those unauthorized derivative software programs which have an undue impact upon the market for the underlying program, is one way to attain this objective. ${ }^{248}$ The software derivative work right would preserve the property

subsequent uses.

Id. at 262-63 (footnotes omitted).

247. See 17 U.S.C. $\$ 117(2)$; Pamela Samuelson, Should Economics Play a Role in Copyright Law and Policy?, 1 U. Otтawa L. \& Tесн. J. 1, 3 (2003-04) ("The principal justification for intellectual property . . . laws in the Anglo-American tradition is economic. Without a grant of exclusive rights, innovators would have too little incentive to invest in socially beneficial innovations for this simple reason: developing the first embodiment of an innovation generally requires a very substantial investment; subsequent copies are generally far less costly to make, and are often trivially cheap and easy."); Yoo, supra note 205, at 214-15 ("If authors are to break even, the per-copy price they charge for a must cover both a portion of the fixed costs needed to produce the work in the first place ... as well as the incremental cost of making the particular copy sold.... Allowing third parties to copy freely would allow those third parties to underprice original authors, because the prices charged by those third parties would need only to cover the costs of producing an additional copy without having to include any surplus to defray the first-copy costs incurred by the authors. This would deprive authors of any reasonable prospect of recovering their fixed-cost investments and would thus leave rational authors with no economic incentive to invest in the production of creative works."); supra Parts II, III.

248. There have been other proposals proffered to broaden the public's right to modify and adapt copyrighted material in the digital age. See, e.g., Michael J. Madison, Social Software, Groups, And Governance, 2006 Mich. ST. L. REV. 153, 164-76 (discussing the impact of digital technological advances upon social group norms and the social benefits of intellectual property "de-regulation"); Durham, supra note 21, at $854-55$ ("I suggest ... recognizing a consumer's fair use right to modify a copyrighted work for private consumption if the modification is ephemeral or if the consumer possesses a copy of a work available in many copies, and the modification alters, at most, only that particular copy."). Indeed, the fact that an unauthorized use of a copyrighted work is undertaken in a non-competing market is also a 
right incentives of program developers while enhancing the opportunities for creative modification and adaptation of protected programs with concomitant benefits to society as a whole. ${ }^{249}$ The proposed narrowing "of the derivative work right" would permit incremental variation upon the function embodied within a program's creative expression while preserving the copyright market for the underlying program, such as where the program is modified towards

consideration in the implementation and enforcement of many international canons for copyright protection. See Daniel J. Gervais, Towards a New Core Copyright International Norm: The Reverse Three-Step Test, 9 Marq. Intell. Prop. L. Rev. 1, 13-14 (2005) (“The Berne Convention contains a general rule, known as the 'three-step test,' which guides national legislators ... with respect to the right of reproduction. ... [T] he so-called three-step-test allows exceptions to the reproduction right: 1) in certain special cases; 2) that do not conflict with the normal commercial exploitation of the work; and 3) do not unreasonably prejudice the legitimate interests of the author. . . . The three-step test has become the cornerstone for almost all exceptions to all intellectual property rights at the international level. It has been used as the model for exceptions to all copyright rights in the TRIPS Agreement (Article 13), to the rights created by the WIPO Copyright Treaty (Article 10), and the WIPO Performances and Phonograms Treaty (Article 16). Interestingly, in the TRIPS Agreement, it is also the basis for exceptions to industrial design protection (Article 26(2)), and patent rights (Article 30)." (footnotes omitted)).

249. See Lemley \& O'Brien, supra note 7, at 265-66 (“[I]ncreased productivity [from software reuse] results from the fact that companies develop fewer programs from scratch, [and] extends beyond the coding phase to corresponding improvements in documentation, testing, and maintenance productivity. Both vertical reuse of software components within a particular department and horizontal reuse of software components across a large number of unrelated projects may reduce aggregate labor costs. Reuse may also reduce labor costs by encouraging internal specia lization or by capitalizing on external specialists as sources of reuse components, since specialization tends to increase efficiency. This potential savings in development and testing time not only translates into a reduction in development costs, but also reduces the time-to-market, which is critical to success in the fast-paced software industry." (footnotes omitted)). See generally Computer Assocs. Int'1, Inc. v. Altai, Inc., 982 F.2d 693, 696 (2d Cir. 1992) ("[T]he copyright law seeks to establish a delicate equilibrium. On the one hand, it affords protection to authors as an incentive to create, and, on the other, it must appropriately limit the extent of that protection so as to avoid the effects of monopolistic stagnation. In applying the [copyright law] to new types of cases, courts must always keep this symmetry in mind."); Raymond T. Nimmer, Licensing in the Contemporary Information Economy, 8 WASH. U. J.L \& POL'Y 99, 146 n.94 (2002) (“'A]rguably, a person will be less likely to undertake the task of writing a book if at the end of the day there will be no ability to control distribution of the work or to obtain financial benefits from the distribution. Similarly, expensive motion picture projects will be less likely to occur if the developer of the work knows that the completed motion picture can be freely appropriated by anyone who chooses to do so. On the other hand, of course, the book or movie, once created, may serve as a basis for work by subsequent persons, thus establishing the peculiar circle that arises in reference to all forms of property law: creating protected rights benefits the current rights owner, but creating too strong of rights may impinge on the creation of subsequent value by other parties."); Durham, supra note 21, at 855 ("Copyright is, primarily, a means to 'increase . . . the harvest of knowledge.' By providing authors certain exclusive economic rights, assuring 'contributors to the store of knowledge a fair return on their labors,' copyright encourages the production of expressive works to inform and entertain the public. Authors forced to compete for sales with copiers, whose prices need reflect only the costs of duplication and not the potentially much higher costs of authorship, could find their efforts unprofitable. ... It must be remembered, however, that the primary beneficiary of copyright law is the public." (footnotes omitted)). 
an entirely new application. ${ }^{250}$ Moreover, making copyrighted programs available for adaptation to new applications and their concomitant markets provides protection more closely related to that provided by functional and quasi-functional intellectual property regimes. ${ }^{251}$ Thus, identifying the copyright holder's legitimate market and incentive interests and permitting unauthorized program modification that does not threaten these interests balances the competing constituent interests and furthers the overarching goals of the copyright law. ${ }^{252}$

250. See Litman, supra note 47, at 965-67 ("Our copyright law is based on the charming notion that authors create something from nothing, that works owe their origin to the authors who produce them.... The process of authorship, however, is more equivocal than that romantic model admits. To say that every new work is in some sense based on the works that preceded it is such a truism that it has long been a cliché ... This is not parasitism: it is the essence of authorship... Because copyright's paradigm of authorship credits the author with bringing something wholly new into the world, it sometimes fails to account for the raw material that all authors use. This tendency can distort our understanding of the interaction between copyright law and authorship. Specifically, it can lead us to give short shrift to the public domain by failing to appreciate that the public domain is the law's primary safeguard of the raw material that makes authorship possible." (footnotes omitted)); Ghosh, supra note 240, at 215 ("The right to exclude serves to provide an incentive to produce and disseminate creative and innovative works. . . In the context of intellectual property, my ability to exclude your access to my work may create impediments to your ability to create your own work. . . When intellectual property constricts the information commons, our commitment to exclusivity has to give way to the need for open access.").

251. As discussed above, utilitarian and quasi-utilitarian intellectual property regimes permit greater flexibility with respect to unauthorized variation upon the creative elements of protected works. Patent law addresses the issue through the doctrine of equivalents and blocking patents. Similarly, trademark law precludes the use or variation upon a distinctive mark where such use or variation is likely to cause confusion in the market place. However, the fact that a similar mark is being used in connection with an entirely different line of business is a factor that is typically viewed as decreasing the likelihood of confusion, particularly if the owner of the original mark is not likely to enter the market in which the subsequent mark is being used. See, e.g., Fred W. Amend Co. v. Am. Character Doll Co., 223 F.2d 277 (C.C.P.A. 1955); Time, Inc. v. T.I.M.E. Inc., 123 F. Supp. 446 (S.D. Cal. 1954); AMF Inc. v. Sleekcraft Boats, 599 F.2d 341 (9th Cir. 1979); Polarad Corp. v. Polarad Electronics Corp., 287 F.2d 492, 495 (2d Cir. 1961).

252. See Madison, supra note 248, at 154 ("The social dimension of computing reminds us that computing is about people, not merely about information. Computing builds connections, networks, and pathways for information and activity, channels that constrain the individual and that enable the group.... [W] e should look for value in the social dimensions of computing; as matters of law and policy, therefore, we should look for ways to enhance — and, where appropriate, to limit - that social character." (footnote omitted)); Litman, supra note 47, at 969 ("The purpose of the copyright law is to encourage authorship. When we embody that encouragement in property rights for authors, we can lose sight of a crucial distinction: Nurturing authorship is not necessarily the same thing as nurturing authors. When individual authors claim that they are entitled to incentives that would impoverish the milieu in which other authors must also work, we guard against protecting authors at the expense of the enterprise of authorship."). 
Narrowing the Derivative Work Right to Preclude Only Unauthorized Derivative Programs That Unduly Impact the Market for the Original Work

Delineating the commercial market for a copyrighted work has long been an arduous task for the courts. ${ }^{253}$ On the one hand, the mere fact that someone has found a way to profit from the use of a copyrighted work does not automatically render that use one within the commercial or "copyright market" for the work. ${ }^{254}$ On the other hand, where the use involves engagement in one or more of the copyright holder's exclusive rights, copyright law effectively presumes that the use falls within the copyright holder's copyright market. The alleged infringer may attempt to defend her use, however, by resort to the fair use doctrine. ${ }^{255}$ In essence, the defendant argues that her encroachment

253. See, e.g., Campbell v. Acuff-Rose Music, Inc., 510 U.S. 569 (1994); Harper \& Row, Publishers, Inc. v. Nation Enters., 471 U.S. 539 (1985); Sony Corp. of Am. v. Universal City Studios, Inc., 464 U.S. 417 (1984); see also Okediji, supra note 10, at 124-26 ("Consistent with the contraction of public welfare norms, the 1976 Act extended protection to derivative works. . . . Derivative rights extended the reach of copyright beyond the original work to the popular subjects of fair use under common law, such as abridgments and compilations.... The protection of derivative rights, at least in theory, makes navigation between protected rights and works that constitute legitimate uses an onerous process." (footnotes omitted)); Samuelson, supra note 247, at 6-7 ("Many copyright professionals have backgrounds in fields other than economics and are more inclined to embrace a romantic conception about art and literature and the people and firms who create and commercialize copyrighted works. This tendency disinclines them to look to economics for guidance about how the law should be crafted."); Mtima, supra note 142, at 432-35, $439-43$.

254. For example, the profitable use of a work that does not involve engagement in any of the exclusive rights is typically outside the copyright market for the work: "An unlicensed use of the copyright is not an infringement unless it conflicts with one of the specific exclusive rights conferred by the copyright statute." Sony Corp. of Am., 464 U.S. at 447; see also Twentieth Century Music Corp. v. Aiken, 422 U.S. 151, 154-55 (1975). Thus, while literary, theater, and movie critics are paid to review and comment upon copyrighted works everyday, reading and commenting are uses available to the public, the copyright holder has no right to demand a royalty in connection with such "commercial use" of her work. Teleprompter Corp. v. Columbia Broad. Sys., Inc., 415 U.S. 394, 398 n.2 (1974) ("Use of copyrighted material not in conflict with a right secured [as an exclusive right], no matter how widespread, is not copyright infringement. ... [Public] 'use short of infringement is to be encouraged."'); Fortnightly Corp. v. United Artists Television, Inc., 392 U.S. 390, $393-95$ (1968) ("The Copyright Act does not give a copyright holder control over all uses of his copyrighted work. Instead, $\S 1$ of the Act enumerates several 'rights' that are made 'exclusive' to the holder of the copyright. If a person, without authorization from the copyright holder, puts a copyrighted work to a use within the scope of one of these 'exclusive rights,' he infringes the copyright. If he puts the work to a use not enumerated in $\S 1$, he does not infringe." (footnotes omitted)). Indeed, even where there is unauthorized engagement in the copyright holder's exclusive rights which harms the commercial market for the work, such as where the use is an unfavorable parody of the copyrighted work, the copyright holder does not control such use. See, e.g., Campbell, 510 U.S. at 591-92.

255. The fair use defense requires the assessment of at least four express factors, one of which is the impact of the use on the market for the work. 17 U.S.C. $\S 107$ (2006) states:

Notwithstanding the provisions of sections 106 and 106A, the fair use of a copyrighted work, including such use by reproduction in copies or phonorecords or by any other means specified by 
upon the copyright holder's exclusive rights should be excused because, inter alia, her use does not in fact harm the copyright holder's copyright market. ${ }^{256}$

Fair use jurisprudence is thus replete with copyright market impact analyses. ${ }^{257}$ In Sony Corp. of America v. Universal City Studios, Inc., ${ }^{258}$ the Supreme Court articulated the prevailing standard for determining the copyright market for a work in connection with an unauthorized use of the work:

The purpose of copyright is to create incentives for creative effort. ... But a use that has no demonstrable effect upon the potential market for, or the value of, the copyrighted work need not be prohibited in order to protect the author's incentive to create. [Where the use is noncommercial] [t] he prohibition of such noncommercial uses would merely inhibit access to ideas without any countervailing benefit. . . . A challenge to a noncommercial use of a copyrighted work requires proof either that the particular use is harmful, or that if it should become widespread, it would adversely affect the potential market for the copyrighted work.... What is necessary is a showing by a preponderance of the evidence that some meaningful likelihood of future harm exists. If the intended

that section, for purposes such as criticism, comment, news reporting, teaching (including multiple copies for classroom use), scholarship, or research, is not an infringement of copyright. In determining whether the use made of a work in any particular case is a fair use the factors to be considered shall include-

(1) the purpose and character of the use, including whether such use is of a commercial nature or is for nonprofit educational purposes;

(2) the nature of the copyrighted work;

(3) the amount and substantiality of the portion used in relation to the copyrighted work as a whole; and

(4) the effect of the use upon the potential market for or value of the copyrighted work.

256. The fair use defense can be invoked in connection with unauthorized engagement in any of the exclusive rights, including the preparation of a derivative work. Accordingly, the fourth fair use factor is concerned with assessing the impact on the market for a work as a whole, whichever specific exclusive right is at issue. In assessing a use under the fourth factor, a court seeks to identify and evaluate any cognizable copyright market impact, including impact on derivative markets. See Campbell, 510 U.S. at 590; Harper \& Row, Publishers, Inc., 471 U.S. at 568. Consequently, a use that has no copyright market impact for purposes of fair use should also have no copyright market impact for purposes of assessing infringement of a particular exclusive right. See, e.g., Iowa State Univ. Research Found., Inc. v. American Broad. Cos., 621 F.2d 57 (2d Cir. 1980); Meeropol v. Nizer, 560 F.2d 1061, 1070 (2d Cir. 1977).

257. See Frank Pasquale, Breaking the Vicious Circularity: Sony's Contribution to the Fair Use Doctrine, 55 CASE Wes. Res. L. Rev. 777, 783-84 (2005) ("Like the fair use doctrine generally, 'effect on the market' analysis is in flux. There are a few fixed guideposts: clearly commercial uses are suspect, and 'transformative' or 'productive' uses are treated more favorably than mere copying. Courts must keep in mind not only the case at hand, but also its potential ramifications: a use is not fair if 'it would adversely affect the potential market for the copyrighted work' should it 'become widespread." (footnote omitted)). See generally Wendy J. Gordon, Fair Use as Market Failure: A Structural and Economic Analysis of the Betamax Case and its Predecessors, 82 Colum. L. Rev. 1600 (1982).

258. 464 U.S. 417 (1984). 
use is for commercial gain, that likelihood may be presumed. But if it is for a noncommercial purpose, the likelihood must be demonstrated. ${ }^{259}$

While the Sony standard distinguishes between commercial and noncommercial uses with respect to the burden of proof of actual harm ${ }^{260}$ to a copyright market, ${ }^{261}$ it nonetheless emphasizes that merely theoretical or speculative assertions of market injury will not establish copyright market injury in either case. ${ }^{262}$ Commentators have observed that the standard articulated in Sony prevents extension of the copyright market to encompass every conceivable use for the work. ${ }^{263}$ Sony therefore avoids the circular

259. Id. at $450-51$.

260. But see Campbell, 510 U.S. at 591 ("No 'presumption' or inference of market harm that might find support in Sony is applicable to a case involving something beyond mere duplication for commercial purposes.").

261. Whether the Sony presumption regarding copyright market injury from an unauthorized commercial use should apply to a market impact analysis under the proposed software derivative work right is open to reasonable debate. An argument in favor of applying the presumption is that given the low threshold of copyright creativity necessary for qualification as a derivative work, the presumption would serve as an additional bulwark against competition from derivative works that are nearly identical to the original program. An argument against applying the presumption is that the equities that underlie its application in connection with the fair use doctrine, an "equitable rule of reason," are less relevant to the construction and application of a derivative work right for functional works. There are additional arguments on either side. For the present analysis, however, the presumption will be applied inasmuch as its affects are counterbalanced by the invocation of a complementary fair use principal - that of a transformative use outweighing its commercial nature. See id. at 579 ("Although such transformative use is not absolutely necessary for a finding of fair use the goal of copyright, to promote science and the arts, is generally furthered by the creation of transformative works. Such works thus lie at the heart of the fair use doctrine's guarantee of breathing space within the confines of copyright and the more transformative the new work, the less will be the significance of other factors, like commercialism, that may weigh against a finding of fair use." (citations omitted)); see also Micro Star v. Formgen Inc., 154 F.3d 1107, 1113 (9th Cir. 1998); Durham, supra note 21, at 869 ("Transformative uses are favored because they further the goal of copyright .... A transformative work is a new work, offering additional expression or a new point of view. Moreover, to the extent that the work is genuinely 'transformed' in comparison to the original, it is less likely to substitute for the original in the marketplace. Consumers attracted to Roy Orbison's version of 'Oh Pretty Woman' . . . are unlikely to consider 2 Live Crew's impressionistic rap parody an acceptable substitute." (footnote omitted)). Thus where the program is being is adapted to perform an entirely different function, for example, a coffee brewing water temperature program adapted for use in a muscle massage device, the use is arguably transformative. Moreover, such a use has little impact on the market for coffee brewing. Consequently, whatever unfavorable presumption that might attach to the commercial nature of such a derivative program can be overcome by its transformative nature, as well as evidence that it has little or no impact on the commercial market for the underlying work.

262. Sony Corp. of Am., 464 U.S. at 451, 456.

263. See, e.g., Pasquale, supra note 257, at 810 ("Sony either limited the range of "traditional, reasonable, or likely to be developed' markets that could be claimed by the copyright owner, or determined that negative effects in one such market would likely be swamped by positive effects in other markets.... Either interpretation ... expands the range of evidence that must be considered before a court can deny a fair use defense."). 
reasoning that has permitted some courts to find that an unauthorized use falls within the copyright market for a work simply because the use is a commercially viable one. ${ }^{264}$

A key flaw in the reasoning of the "commercially viable use equals copyright market" decisions is the failure to give proper deference to the fact that, as a positive social utility regime, American copyright law does not reserve all profitable or commercial uses of a copyrighted work to the copyright holder. ${ }^{265}$ Thus, the fact that an alleged infringer is using the work,

264. This is essentially the view of the dissent in Sony:

First, an infringer cannot prevail merely by demonstrating that the copyright holder suffered no net harm from the infringer's action. Indeed, even a showing that the infringement has resulted in a net benefit to the copyright holder will not suffice. Rather, the infringer must demonstrate that he had not impaired the copyright holder's ability to demand compensation from (or deny access to) any group who would otherwise be willing to pay to see or hear the copyrighted work. Second, the fact that a given market for a copyrighted would not be available to the copyright holder were it not for the infringer's activities does not permit the infringer to exploit that market without compensating the copyright holder.

Sony Corp. of Am., 464 U.S. at 485 (Blackmun, J., dissenting). In short, if the infringer can turn a profit through the contested use of the work, so could the copyright holder, and thus, the use should be considered one within the copyright market for the work. Commentators have observed the speculative nature of a work's copyright market under this approach. See, e.g., Pasquale, supra note 257, at 783-84; Hannibal Travis, Building Universal Digital Libraries: An Agenda for Copyright Reform, 33 Pepp. L. Rev. 761, 814, 822 (2006) ("[The fair use] doctrine in its current form has little to offer . . . becau se courts have eviscerated it. These courts have fallen under the influence of a theory that even uses of copyrighted material that have no provable adverse effect on the sales of a work are unfair if there is a 'potential' for harm to schemes for licensing the work.... [The] central focus should return to the actual effects of unauthorized uses on revenue or profits earned on copyrighted works, rather than speculation about conceivable harms to 'potential' markets for such works.").

265. See Campbell, 510 U.S. at 584 ("[T] $]$ he mere fact that a use is educational and not for profit does not insulate it from a finding of infringement, any more than the commercial character of a use bars a finding of fairness."); see also H.R. REP. No. 60-2222, at 7 (1909) (“The enactment of copyright legislation by Congress under the terms of the Constitution is not based on any natural right that the author has in his writings ... but upon the ground that the welfare of the public will be served and progress of science and useful arts will be promoted by securing to authors for limited periods the exclusive rights to their writings.... In enacting a copyright law, Congress must consider two questions: first, how much will the legislation stimulate the producer and so benefit the public; and second, how much will the monopoly granted be detrimental to the public? The granting of such exclusive rights, under the proper terms and conditions, confers a benefit upon the public that outweighs the evils of the temporary monopoly."); 2 Nimmer \& Nimmer, supra note $2, \S 8.01$ [A], at 8-15 (“[N] ot every unauthorized exploitation of a work ... necessarily infringes the copyright. As the Supreme Court expresses the matter, copyright 'protection has never accorded the copyright owner complete control over all possible uses of his work.' Thus, the suggestion in certain cases that use alone constitutes infringement is in error. More precisely, the use of a copyrighted work, to the extent not falling within the scope of those rights expressly granted to the copyright proprietor, does not infringe. To give some examples, 'maintaining' copyrighted computer code does not infringe. Privately reading a literary work and privately performing a dramatic or musical work constitute non-infringing uses. All the more so, no cause of action exists under the Copyright Act for withholding tangible copies of works and thereby purportedly preventing their exploitation. It would also 
even if that use is commercial and/or injurious to the copyright holder's commercial interests, does not necessarily mean that the use and any concomitant commercial market is within the copyright market for the work. ${ }^{266}$ "[A] potential market ... has always been supplanted in every fair use case, to the extent that the defendant ... has made some actual use of plaintiff's work, which use could in turn be defined in terms of [a] . . potential market."267 A rule that equates commercially viable use with "copyright market" circuitously concludes that every use which turns a profit falls within or has a negative impact upon the copyright market for the work. ${ }^{268}$ Thus,

seem error to hold infringing the mere act of registering a copyright, without any reproduction, distribution, public performance, etc. of the work in question." (footnotes omitted)). See generally Lateef Mtima, Natural Law and Positive Social Utility in the Digital Copyright Age, in Ad Honorem Ion Dogaru: Studi JuRidice Alese 255, 258-59 (2005) ("Congress and the federal courts have determined that unlike natural law regimes, the primary objective underlying American intellectual property law is to engender the broadest possible production and dissemination of creative works and inventions.... [T] The mechanism of exclusive rights is counterbalanced by the fact that outside of these rights, the public is free to use, enjoy, and build upon protected works. ... Accordingly, when an entirely new means for exploiting [a copyrighted work] is developed . . . it is not axiomatic that the creator of the [work] owns or controls the right to exploit her [work] in this new manner."); Marci A. Hamilton, Copyright at the Supreme Court: A Jurisprudence of Deference, 47 J. COPYRIGHT Soc'Y U.S.A. 317, 319 (2000); Pierre N. Leval, Toward A Fair Use Standard, 103 HARV. L. Rev. 1105, 1107 (1990); Jason S. Rooks, Note, Constitutionality of Judicially Imposed Compulsory Licenses in Copyright Infringement Cases, 3 J. InTELL. Prop. L. 255 (1995).

266. See, e.g., Campbell, 510 U.S. at 591-92 ("[W]hen a lethal parody, like a scathing theater review, kills demand for the original, it does not produce a harm cognizable under the Copyright Act.”); Pasquale, supra note 257, at $798 \mathrm{n} .83$ ("This classic distinction in fair use law is intended to exempt certain affects on the market from being considered in the fourth factor inquiry. If a scathing review or cutting parody reduces market sales for a work, it has most likely done so by disparaging the work. This kind of market harm is not counted. However, an abridgement of the work or unauthorized copy may usurp sales simply by substituting for the work. That market harm is counted in the fourth factor inquiry.").

267. 4 Nimmer \& Nimmer, supra note 2, § 13.05[A][4], at 13-196; see also Sega Enters. Ltd. v. Accolade, Inc., 977 F.2d 1510, 1523 (9th Cir. 1992) ("By facilitating the entry of a new competitor, the first lawful one that is not a Sega licensee, Accolade's disassembly of Sega's software undoubtedly 'affected' the market for Genesis-compatible games in an indirect fashion. We note, however, that . . video game users typically purchase more than one game. There is no basis for assuming that Accolade's 'Ishido' has significantly affected the market for Sega's 'Altered Beast,' since a consumer might easily purchase both; nor does it seem unlikely that a consumer particularly interested in sports might purchase both Accolade's 'Mike Ditka Power Football' and Sega's 'Joe Montana Football,' particularly if the games are, as Accolade contends, not substantially similar.").

268. See Pasquale, supra note 257 , at 778 . Indeed, if the view of the Sony dissent were adopted, there would be no need to express the fourth fair use factor in terms of market impact; the copyright holder would need only to demonstrate defendant's engagement in an unauthorized use, from which some potential market harm could be inferred. But see Goldstein, supra note 149, at 232-33 ("The problem with the potential market factor is that courts have given the term 'potential' a far narrower construction than is appropriate in light of the Copyright Act's expansive grant of derivative rights. ... [T] he Act gives the author of a novel excusive rights not only to the market for hardcover sales, but also to paperback sales, 
under Sony, copyright market injury must be more than theoretical to preclude an unauthorized use of a work. ${ }^{269}$

The courts have had some occasion to evaluate the alleged affects of unauthorized derivative works upon the commercial market for an underlying software program. For example, in Midway Manufacturing Co. v. Artic International, Inc., ${ }^{270}$ the plaintiff manufactured video games and game machines, and the defendant manufactured circuit boards that, when inserted into plaintiff's machines, "speeded up" the video games' audiovisual images. ${ }^{271}$ Plaintiff brought suit alleging, inter alia, copyright infringement on the grounds that the speeded-up images constituted the unauthorized creation of derivative versions of plaintiff's audiovisual works.

In deciding whether the speeded-up images constituted derivative works, the court compared them to "playing at 45 or 78 revolutions per minute ('RPM's') a phonograph record recorded at 33 RPM's."272 The court reasoned that while speeded-up recordings would not constitute derivative works, speeded-up video games do constitute derivative works because of the latter's impact upon the copyright market for the underlying work:

There is this critical difference between playing records at a faster than recorded speed and playing video games at a faster than manufactured rate: there is an enormous demand for speeded-up video games but there is little if any demand for speeded-up records. ... Speeding up a video game's action makes the game more challenging and exciting and increases the licensee's revenue per game. Speeded-up games end sooner than normal games and consequently if players are willing to pay an additional price-per-minute in exchange for the challenge and excitement of a faster game, licensees will take greater total revenues. Video game copyright owners would undoubtedly like to lay their hands on some of that extra revenue.... ${ }^{73}$

Thus, the court emphasized the likely impact of the unauthorized versions upon the commercial market for the underlying work as dispositive of its classification as a derivative work. While the Midway court may go too far

\footnotetext{
magazine serialization or condensation, and motion picture and television productions, to list just the major potential markets. ... Yet, courts applying the potential market factor have generally inclined to identify potential markets with the market in which the work was first introduced or, at most, with closely bordering markets."). As is typically the case, the best approach lies somewhere in between the extremes; the emphasis should be placed upon the relationship between the original market and those served by the unauthorized work and not merely on whether the unauthorized use is a commercial or profitable one.

269. Sony Corp. of Am., 464 U.S. at $451,456$.

270. 704 F.2d 1009 (7th Cir. 1983).

271. Id. at 1010-11.

272. Id. at 1013.

273. $I d$.
} 
in holding that a lack of market impact alone would automatically disqualify a version for characterization as a derivative work, ${ }^{274}$ the absence of copyright market injury is a compelling consideration in determining whether an unauthorized work infringes the derivative work right. ${ }^{275}$

$[\mathrm{T}]$ he additional value to the copyright owner of having the right to market separately the speeded-up version of the recorded performance is too trivial to warrant legal protection for that right. A speeded-up video game is a substantially different product from the original game. ... For that reason, the owner of the copyright on the game should be entitled to monopolize it on the same theory that he is entitled to monopolize the derivative works specifically listed in Section $101 .^{276}$

Similarly, the court in Vault Corp. v. Quaid Software Ltd. held that where the allegedly infringing program performs a different function than that of the original work, the subsequent program does not infringe the derivative work right attendant to the original program. ${ }^{277}$ As discussed in Part II, the defendant in Vault developed its RAMKEY program to "trick" computers into thinking that it was the plaintiff's PROLOK program. ${ }^{278}$ Because PROLOK and RAMKEY performed entirely different (indeed, opposing) functions, the court consequently ruled that RAMKEY was not a derivative version of PROLOK:

The cases upon which Vault relies . . . involved situations where the derivative work performed essentially the same function as the copyrighted work. In this case, Vault's

274. While the protection of market interests is obviously a salient objective of the derivative work right, market impact is not an express element in the definition of a derivative work under section 101. See, e.g., Lewis Galoob Toys, Inc. v. Nintendo of Am., Inc., 964 F.2d 965, 969 (9th Cir. 1992) (“[T] he existence of a market does not ... determine conclusively whether a work is an infringing derivative work."). Under the proposed software derivative work right (applicable only to software programs) unauthorized programs which qualify as derivative works but do not unduly impact the copyright market for the original program are still derivative works, merely a class of derivative works that the copyright holder does not control.

275. See Goldstein, supra note 149, at 211 ("The fact that the Copyright Act aims to encourage investment in original and derivative works alike seriously complicates the determination whether a particular derivative work infringes an original work.").

276. Midland Mfg. Co., 704 F.2d at 1014; see also Suntrust Bank v. Houghton Mifflin Co., 268 F.3d 1257, 1274 (11th Cir. 2001); Micro Star v. Formgen Inc., 154 F.3d 1107, 1113 (9th Cir. 1998); Fisher v. Dees, 794 F.2d 432, 438 (9th Cir. 1986); Consumers Union of U.S., Inc. v. General Signal Corp., 724 F.2d 1044, 1050 (2d Cir. 1983); Harper \& Row, Publishers, Inc. v. Nation Enters., 723 F.2d 195, 208 (2d Cir. 1983); Foresight Res. Corp. v. Pfortmiller, 719 F. Supp. 1006, 1008-1 0 (D. Kan. 1989); Salinger v. Random House, Inc., 650 F. Supp. 413, 425 (S.D. N.Y. 1986) (finding that defendant's quotation of plaintiff's letters in no way diminishes the marketability of the letters among plaintiff's readers), rev' $d, 811$ F.2d 90 (2d Cir. 1987) (holding impairment of market likely), cert. denied, 484 U.S. 890 (1988).

277. 847 F.2d 255, 268 (5th Cir. 1998).

278. Id. at 257 . 
program and RAMKEY serve opposing functions; while Vault's program is designed to prevent the duplication of its customers' programs, RAMKEY is designed to facilitate the creation of copies of Vault's customers' programs. ... We therefore reject Vault's contention that . . RAMKEY constitutes a derivative work. ${ }^{279}$

Reconciled with the principal objectives of the derivative work right and the copyright market parameters enunciated in Sony, the decisions in Midway and Vault can be construed as requiring that courts confirm that an unauthorized derivative work will have some concrete impact upon the legitimate copyright market expectations of the copyright holder before holding that the unauthorized work infringes the derivative work right. ${ }^{280}$ Thus, because recording artists have few, if any, expectations regarding markets for speeded-up versions of their works, but video game manufacturers might reasonably expect to gain from faster and more challenging versions of their protected games, only unauthorized works in the latter case can be reasonably said to misappropriate legitimate copyright market interests. ${ }^{281}$

279. Id. at 268 (citations omitted); see also Lexmark Int'l, Inc. v. Static Control Components, Inc., 387 F.3d 522, 544 (6th Cir. 2004) (analyzing the first fair use factor and noting that where the unauthorized use utilizes the work for a purpose different from that of the original work, such use might not usurp the work's "commercial value as a copyrighted work"). Indeed, the Vault decision provides wider latitude than what would be available under the proposed software derivative work right, in that the Vault rationale seems to ignore the possible market impact of a derivative version which performs a different function from that of the underlying work. While the fact that the subsequent work performs a different function than that of the underlying work is typically indicative of its copyright market impact, it is by no means irrefutably conclusive. In a case such as Vault in which the subsequent work is essentially designed to impair the market for the original work, it seems perverse to ignore the fact that portions of the copyrighted work were used without permission to create the later work. This would seem to qualify as a derivative work that impairs the market for the original work, notwithstanding the works' differing functions. Similar to the case of a parody, any latitude extended in such a case is more appropriately considered within the context of the fair use doctrine, in connection with which additional equitable factors (such as any transformative qualities of the later work) are taken into account. Needless to say, the foregoing concerns regarding market impact would not be relevant in the case of an entirely original program which has a similarly devastating effect upon the market for a preexisting work.

280. Foresight Res. Corp., 719 F. Supp. at 1009-10. In weighing the social benefit of unauthorized program modifications against the likelihood of actual copyright market injury, the Foresight court observed that unauthorized derivative works do not always threaten the commercial market for the original work: "The comparison of [program modification] to extensive marginal note-taking in a book is approp riate: note-taking is arguably the creation of a derivative work, but unless the note-taker tries to copy and vend that work, the copyright owner is unlikely to be very concerned." Id.; see also Campbell v. AcuffRose Music, Inc., 510 U.S. 569, 591 (1994) ("[W]hen . . . the second use is transformative, market substitution is at least less certain, and market harm may not be so readily inferred.... This is so because the [transformative use] and the original usually serve different market functions.").

281. In addition, "speeded-up" versions and similar uses of copyrighted works will typically be addressed under the reproduction right, particularly because "speeding-up" usually does not involve copyright creativity. 
Similar "market expectation" arguments can be made with respect to derivative programs designed to perform different and/or opposing functions as compared with that of the original work.

The proposed software derivative work right adapts the Sony standard to the unique realities of software programs as copyrightable works by implementing the pragmatic rationales of Midway and Vault. The proposed derivative right acknowledges that the copyright law does not reserve all uses and markets for a protected program to the copyright holder, but only those necessary to provide a sufficient incentive to create additional works. ${ }^{282}$ Concededly, these market interests extend beyond the immediate or direct markets for the work. Returning to the hypothetical coffee brewing machine and water temperature program, the relevant copyright market should extend to indirect markets such as adapting the water temperature program for use in automatic tea brewers or other beverage makers as reasonably anticipated indirect markets for the original program. ${ }^{283}$

282. Sony Corp. of Am. v. Universal City Studios, Inc., 464 U.S. 417, 431-32 (1984) (“The limited scope of the copyright holder's statutory monopoly ... reflects a balance of competing claims upon the public interest: Creative work is to be encouraged and rewarded, but private motivation must ultimately serve the cause of promoting broad public availability of literature, music, and the other arts.... The sole interest of the United States and the primary object in conferring the [author's] monopoly ... lie in the general benefits derived by the public from the labors of authors." (internal quotes omitted) (quoting Fox Film Corp. v. Doyal, 286 U.S. 123, 127 (1932)); Lessig, supra note 158, at 35 ("We first imagine a creative work mixed together by someone; and then someone else remixes that creative work. In this sense, culture is remix. Knowledge is remix. Politics is remix .... Corporations engage in remix .... You watch a movie... and you whine to your friends that this is the best movie you have ever seen, or the worst movie ever made, and you are using [this] work in your life. You are remixing it into your life and sharing that remix with others. In that process, you are changing the world in tiny little ways. You are changing the way our culture is. You are constructing and reconstructing culture by these acts that you engage in. Every single act of reading and choosing and criticizing and praising our culture is, in this sense, remix. This is how cultures get made.").

283. See, e.g., Goldstein, supra note 149, at 227 ("Derivative rights affect the level of investment in copyrighted works by enabling the copyright owner to proportion its investment to the level of expected returns from all markets, not just the market in which the work first appears .... The publisher who knows that it can license, and obtain payment for, the translation, serialization, condensation, and motion picture rights for a novel will invest more in purchasing, producing, and marketing the novel than it would if its returns were limited to revenues from book sales in the English language." (emphasis omitted)); Jessica Litman, The Exclusive Right to Read, 13 CARDOzo ARTs \& EnT. L.J. 29, 43 (1994) ("This is the central justification for further enhancing the rights in the copyright bundle: without strong copyright protection, there will be no national information infrastructure. The public might believe that what it wants is unfettered access to copyrighted works in return for reasonable royalty payments to authors, but, if we let the public set the freight charges, we risk underproduction of freight. If authors and publishers cannot reliably control their works, they will decline to make them available at all.”); Michael G. Anderson \& Paul F. Brown, The Economics Behind Copyright Fair Use: A Principled and Predictable Body of Law, 24 LoY. U. CHI. L.J. 143, 158-59 (1993) ("Copyright law vests a bundle of rights in the creator of certain kinds of intellectual property.... Copyright law, both ancient and modern, is founded on the fundamental, though 
To the extent that unauthorized derivative programs implicate market opportunities beyond the copyright holder's reasonable expectations, however, they involve "market interests" outside the copyright market and therefore comprise opportunities that the copyright law does not reserve as exclusive to the copyright holder. ${ }^{284}$ In addition, the functional nature of software programs, and the accompanying considerations of social efficiency, provide a compelling basis for permitting unauthorized derivative versions of software programs in the absence of cognizable copyright market injury. ${ }^{285}$ Moreover,

perhaps implicit, notion that adverse economic incentives are created if unrestricted [use] of intellectual products is permitted. When adverse incentives exist, society will not have as much creative innovation as it wishes to encourage. Therefore, the emphasis of copyright law is on the benefits derived by the public from the creative efforts of authors. Reward to copyright owners or authors is a necessary but secondary consideration." (footnotes omitted)). Given the functional nature of software programs, the developer of the hypothetical water temperature program might reasonably expect to reuse or adapt her program for use in similar devices, such as tea brewing machines. Consequently, devices which perform similar overall functions or which serve markets related to that served by the original program should be considered within the copyright market for the original program. See, e.g., Time, Inc. v. Life Television Corp., 123 F. Supp. 470, 474-77 (D. Minn. 1954); see also Gervais, supra note 248, at 29 (Proposing a similar approach through a combination of American fair use and the Berne Convention three-step test: "Use that interferes with normal commercial exploitation or unreasonably or unjustifiably prejudices the copyright holder's rights. Any use that demonstrably and substantially reduces financial benefits that the copyright owner can reasonably expect to receive under normal commercial circumstances would be 'unfair' without authorization.").

284. See Sony Corp. of Am., 464 U.S. at 429 ("The monopoly privileges that Congress may authorize are neither unlimited nor primarily designed to provide a special private benefit. Rather, the limited grant is a means by which an important public purpose may be achieved. It is intended to motivate the creative activity of authors and inventors by the provision of a special reward, and to allow the public access to the products of their genius after the limited period of exclusive control has expired. 'The copyright law, like the patent statutes, makes reward to the owner a secondary consideration."'). Unanticipated commercial opportunities are not part of an author's incentive to create and, consequently, there is no copyright policy basis upon which to assign them to the copyright market for the work. In appropriate cases, such as in connection with some new technological uses for copyrighted material, Congress has authority to decide whether an unanticipated use or market for copyrighted material should be allocated to the copyright holder. See, e.g., Mtima, supra note 142, at 401-02, 411-12 ("Each time a new technological advance or development provides a new means by which copyrighted works may be used or exploited, a challenge is presented to the balance between the author's incentive/exclusive rights mechanism and the corollary objective of broad public access to creative works. Initially the courts, and often ultimately Congress, must decide whether the "new use" is one that falls within the category of exclusive rights, or if it is a use that should remain freely available to the public.... Consistent with the policy objectives that underlie the copyright law, courts typically resist the entreaties of copyright holders to expand the realm of exclusive rights to a 'default' classification option, to be invoked when confronted with a new technological use that does not easily fit into the exclusive rights/public free access dichotomy. Indeed, traditional judicial construction of American copyright as positive law imposed for the public benefit mandates the rejection of an exclusive rights 'default' approach." (footnotes omitted)).

285. See, e.g., Foresight Res. Corp., 719 F. Supp. at 1009-10; LaFontaine, supra note 6, at 459 (" $[\mathrm{T}]$ he open source development model has different goals in mind from the proprietary code model. For all its ideological underpinnings, the primary objective of F/OSS development is quite functional: to 
by requiring that variations to the original program reflect copyright creativity as a prerequisite to qualification as a derivative work, the software derivative work right further assures that any incidental onus on the interests of the copyright holder is offset by concrete, if minimal, copyright endeavor, as well as the general social utility benefits of additional software programs. ${ }^{286}$

The proposed software derivative work right achieves an appropriate balance between the interests of copyright holders and the software-using public. ${ }^{287}$ Indeed, there are also potential benefits to the authors of underlying programs. By definition, a permitted derivative work services a different market than that of the original program; consequently, the author of the

produce the best code possible by allowing many individuals to participate in its creation. Software of all kinds is often plagued by coding errors called 'bugs,' which cause programs to malfunction or crash. A key component of the open source philosophy is that the best way to produce well written and bug-free software code is to allow a large number of programmers to tinker with it."). See Schaumann, supra note 187, for a similar argument in favor of creative artists "reusing" portions of copyrighted works to create "appropriation art": [E]ffective communication requires artists to use the aesthetic vocabulary of their times. It is hard to imagine commenting to present-day society, about present-day society, without using a present-day aesthetic vocabulary. To do so, however, will infringe copyright. In other words, when the aesthetic vocabulary of a culture becomes private property, copyright is positioned in opposition to art." Id. at 254-55; see also Dan L. Burk, Muddy Rules for Cyberspace, 21 CARdozo L. Rev. 121, 133 (1999); Lawrence Lessig, The Law of the Horse: What Cyberlaw Might Teach, 113 Harv. L. Rev. 501, 527 (1999); William W. Fisher III, Property and Contract on the Internet, 73 CHI.-KENT L. REV. 1203, 1249 (1998).

286. See, e.g., Nicolas, supra note 26 , at 4 ("The basic policy behind federal copyright law is twofold: first, copyright law provides an incentive, mainly economic, to authors in the form of a temporary monopoly over their works to encourage the creation of new works; second, copyright law seeks to provide society with reasonable access to an author's work so others may be exposed to that work and improve upon it.").

287. See Sony Corp. of Am., 464 U.S. at 429 ("Because this task [of promoting the dissemination of creative works] involves a difficult balance between the interests of authors and inventors in the control and exploitation of their writings and discoveries on the one hand, and society's competing interest in the free flow of ideas, information, and commerce on the other hand, our patent and copyright statutes have been amended repeatedly."); Schaumann, supra note 187, at 262 ("Copyright's purpose, then, is to remunerate authors, but not because society believes them to be inherently noble or deserving of remuneration. Instead, copyright aims to benefit society as a whole by ensuring access to more works, and thereby access to more good works. Copyright's essential strategy is to manipulate directly an aspect of the legal system - securing exclusive rights to authors - to accomplish a goal that cannot be achieved by direct manipulationincreasing the quantity and quality of the works to which the public has access."); Hamilton, supra note 265, at 319-21 ("Elements of the [Supreme] Court's . . interpretation of the Copyright Clause . . . include[s] an emphasis on the public good that forces author's right[s] to be conditioned by the public.... From the first case, through the present, the Court has treated copyright law as positive law, the parameters of which are determined by Congress ([as] limited by the Constitution's strictures)."); Leval, supra note 265, at 1107 ("The Supreme Court has often and consistently summarized the objectives of copyright law. The copyright is not an inevitable, divine, or natural right that confers on authors the absolute ownership of their creations. It is designed rather to stimulate activity and progress in the arts for the intellectual enrichment of the public."); see also Barker, supra note 159, at 263 (arguing for a balancing the social equities test in enforcement of patent rights). 
original program would be free to adapt the derivative program for use in her market (i.e., adapting the derivative liquid-heating therapeutic massage program for use in a new tea brewing machine). Thus, the original programmer may get a "leg up" in developing derivative versions and applications of her own original program. ${ }^{288}$ In short, allowing the public the privilege to prepare derivative programs that do not unduly impact the copyright market for the underlying programs would further the social policy of the copyright law to the ultimate benefit of society. ${ }^{289}$

\section{B. The Software Derivative Work Right: A Benediction for Fair Use}

In addition to being consistent with the principal objectives of section $106(2)$ and section 117, adoption of the software derivative work right and the public derivative work privilege would broaden the range and availability of the social utility options typically pursued under the fair use doctrine as codified in section 107. In general, the fair use doctrine permits unauthorized engagement in the exclusive rights where, when evaluated under the four fair use factors, the balance of societal and author interests favor a limited impingement upon the copyright holder's property rights. ${ }^{290}$

288. See Nimmer, supra note 249, at 106 ("Modern transactions in information do not always stem from intellectual property rights; often, such rights are irrelevant. ... Value, rather than property rights, forms the basis for commercial exchange.... Property rights may sometimes be important in a market, but not always. What is critical is that there exists a sufficient basis for an exchange in light of the assets, rights, control, money, knowledge, skill, or access of both parties and in relation to the overall market.”).

289. See Lawrence Lessig, The Future of Ideas: The Fate of the Commons in a Connected WORLD 9 (Vintage Books $2 \mathrm{~d}$ ed. 2002) ("We have the potential to expand the reach of creativity to an extraordinary range of culture and commerce. Technology could enable a whole generation to create-remixed films, new forms of music, digital art, a new kind of storytelling, writing, a new technology for poetry, criticism, political activism - and then, through the infrastructure of the Internet, share that creativity with others. This is the art through which free culture is built.").

290. See, e.g., Sega Enters. Ltd. v. Accolade, Inc., 977 F.2d 1510, 1520-27 (9th Cir. 1992); Madison River Mgmt. Co. v. Bus. Mgmt. Software Corp., 387 F. Supp. 2d 521, 535-37 (M.D.N.C. 2005); Samuelson, supra note 247, at 51 ("Fair use has historically served as a flexible and adaptable mechanism for balancing the interests of copyright owners, their competitors or potential competitors, and the public to fulfill the larger purposes of copyright law which have traditionally been understood to be promoting the production and dissemination of knowledge.”); Leval, supra note 265, at 1105; see also 2 GoldsteIN, supra note $8, \S 7.0 .2$, at 7:7 ("The social judgment in these cases is that, even if transaction costs do not systematically disable negotiated licenses, these users are not only so important but also so characteristically underfunded that they deserve a free ride or, at least, should be required to compensate the copyright holder with no more than a reasonable fee. These social judgments presuppose that the copyright owner will be able to earn returns in other markets that are sufficient to provide it with the incentives it needs to produce copyrighted works in the desired quantity and of the desired quality."). 
For eligible modified programs, adoption of the software derivative work right would effectively reduce the fair use four-factor test to, at most, two factors. In addition to satisfying the fourth factor of market impact, the software derivative work right arguably requires some minimal satisfaction of the first factor, in that it requires that the original program be "transformed" into a derivative work. ${ }^{291}$ Of course, in light of the broad definition of derivative work, in some cases the minimal changes that will qualify as creating a derivative work will not qualify as substantive "transformations" in the usual fair use sense. However, as discussed above, if characterization as a derivative work requires variation that at least meets the threshold of "copyright creativity," then in all software derivative work right cases there will be at least some marginal copyright "transformation" of the original program. ${ }^{292}$ Thus, in satisfying the substantive prerequisites of the derivative work right, an unauthorized derivative program will at least minimally satisfy the first fair use factor. ${ }^{293}$

With regard to the second fair use factor, the nature of the copyrighted work, although disregarded under the proposed software derivative work right, in most cases, its absence from consideration should cause little variation from the results obtained under fair use. This is due to the limited significance of this factor in the assessment of unauthorized uses of factual and utilitarian

291. The first fair use factor, the purpose of the unauthorized use, favors transformative uses of copyrighted works, even when such uses are commercial nature. See, e.g., Campbell v. Acuff-Rose Music, Inc., 510 U.S. 569, 578-79 (1994); Schaumann, supra note 151, at 288 ("Courts and commentators in recent years have stressed the idea that to be fair, a use should be 'transformative.' A transformative use constitutes creative departure from the original work. Access to such a creative departure is presumably in the public interest; if the use meets this criterion, it is more likely to be held non-infringing than if it is not transformative. This analysis dovetails well with the market-impact approach discussed immediately above, insofar as market substitution of a transformative work for the copied work is less likely than the substitution of a non-transformative work: a 'transformative' work is by definition different in some important way from the copied work, and therefore is probably not a good substitute. Thus, to the extent a use is transformative, adverse market impact is less likely." (footnotes omitted)).

292. See discussion supra note 262. Again, revisions that fall below the threshold of copyright creativity should be treated as resulting in the production of a non-literal copy of the original program, not as derivative works. Professor Ochoa appears to share this view: "[I]n the absence of a derivative work right the other four rights could have been construed to be limited to versions which were closely similar to, or nearly identical with, the original fixed version of the work." Ochoa, supra note 172, at 1022.

293. Thus, where the original program is modified toward an entirely different application, the resulting derivative work will likely satisfy the first fair use factor on a variety of levels, as having transformed the work and also in furthering the public interest, another important consideration in weighing the first fair use factor. See, e.g., Sega Enters. Ltd., 977 F.2d at 1523, 1526-27 ("We further note that [in assessing the first fair use factor] we are free to consider the public benefit resulting from a particular use notwithstanding the fact that the alleged infringer may gain commercially."). 
works. ${ }^{294}$ Although not entirely ignored in assessing the unauthorized use of software programs, courts tend to provide wider latitude to defendants in this context, and thus, this factor typically weighs in favor of permitting the unauthorized use. ${ }^{295}$

Consequently, the principal difference between infringement assessments under the software derivative work right, as compared with fair use analyses, will be the absence of consideration of the third fair use factor - the amount and substantiality of the work being used. Under the software derivative work right, even the entire program could be used, provided that such use will have little or no impact on the copyright market for the original program. In evaluating an unauthorized use under the fair use doctrine, however, such extensive use of a copyrighted work typically militates against a finding of fair use. $^{296}$

In sum, the principal social benefit to be achieved through adoption of the software derivative work right is a broader range of permissible "reuses" of greater portions of copyrighted programs. Some unauthorized derivative works that fail the fair use four-factor test could be allowed under the software derivative work right, because, under the latter test, an unauthorized derivative work need only reflect copyright creativity (as opposed to full-fledged copyright transformation) and could involve the "reuse" of virtually any amount of the underlying program in order to be eligible for immunity from infringement liability. Consequently, the creation of both "transformative" (i.e., new application) and "quasi-transformative" (i.e., mere creative variation) derivative works are removed from the exclusive province of the copyright holder, subject to the impact upon the copyright holder's legitimate copyright market interests.

294. See id. at 1524 ("The second statutory factor, the nature of the copyrighted work, reflects the fact that not all copyrighted works are entitled to the same level of protection. The protection established by the Copyright Act for original works of authorship does not extend to the ideas underlying a work or to the functional or factual aspects of the work. To the extent that a work is functional or factual, it may be copied as may those expressive elements of the work that 'must necessarily be used as incident to' expression of the underlying ideas, functional concepts, or facts. Works of fiction receive greater protection than works that have strong factual elements, such as historical or biographical works or works that have strong functional elements, such as accounting textbooks." (citations omitted)).

295. See id.

296. See, e.g., id. at 1526-27; 4 Nimmer \& Nimmer, supra note 2, § 13.05[D][1], at 13-230.9. Of course, the unauthorized use of a substantial portion of copyrighted work is sometimes permissible under the fair use doctrine. In the case of parody, for example, it is often necessary that the parodist use substantial portions of a protected work, and often to the detriment of the work's copyright market, in order to accomplish her critical ends. See, e.g., Campbell, 510 U.S. at 586-89; Sony Corp. of Am. v. Universal City Studios, Inc., 464 U.S. 417, 449-50 (1984). 
Accordingly, the proposed software derivative work right and public derivative work privilege is not merely redundant of fair use; it not only provides an expedient alternative for the creation of derivative programs, but it might also aid in the development of a more uniform fair use jurisprudence. ${ }^{297}$ The public derivative work privilege would provide special latitude in connection with the unauthorized "reuse" of software programs as copyrighted works. Moreover, just as an unauthorized work that does not qualify for fair use might be allowed under the software derivative work right, the reverse would also true. The prohibitive market impact under the software derivative work right could be sufficiently counter-balanced by a highly transformative reuse of a limited portion of a program, which could collectively tip the scales toward permitting an authorized derivative work as a fair use. ${ }^{298}$

\section{CONCLusion}

The functional nature of software programs necessitates special copyright accommodations with respect to the public's ability to modify these works. Congress has acknowledged this by adopting section 117. Congress has left to the courts, however, the responsibility for interpreting and applying section 117 so as to effectuate its ultimate social utility goals. The leading section 117 case law has laid the ground work for a clearer interpretation-initially by clarifying the "essential step utilization" prerequisite and more recently by identifying the copyright holder's commercial market incentives as the sociodoctrinal counterweight to software user modification needs. The larger issue, however, that of the public's ability to modify and build upon copyrighted software programs as a general matter as balanced against the symbiotic

297. See Ochoa, supra note 172 , at 1023 \& n. 162 ("[T] he fair use doctrine is already asked to carry a tremendous portion of the policy considerations present in U.S. copyright law. ... For example, the fair use doctrine has been invoked to determine the legality of home videotaping for time-shifting purposes, educational and corporate photocopying, news reporting, parody and satire, use of letters and film clips in biographies and documentaries, fan and collector's guides, digital sampling, decompilation and reverse engineering, comparative advertising, and internet searching engines."). The adoption of the software derivative work right would make it unnec essary to resort to fair use in most software derivative work cases and would reduce some of the distortion and uncertainty that arises from efforts to utilize fair use to accommodate every socially beneficial intrusion upon a copyright holder's exclusive rights.

298. See, e.g., Campbell, 510 U.S. at 586-90; Sega Enters. Ltd., 977 F.2d at 1522-23, 1527; Schaumann, supra note 187, at 267, 269. 
concern of copyright holders' indirect and derivative market interests, remains largely unaddressed and of imminent significance. ${ }^{299}$

The adoption of the proposed software derivative work right and corollary public derivative work privilege based upon a practical-use versus marketimpact balancing rationale is one means by which to address these concerns and achieve a socially responsible "copyright constituent CON[fluence]." With regard to the public's adaptation privilege, the practical-use versus market-impact balancing rationale further delineates the rights of software users to create and disseminate not only "essential" adaptations, but also "adaptation-derivative works," subject to any undue impact upon the copyright market for the underlying software program. With regard to the derivative work right of copyright holders and their attendant commercial market interests, the software derivative work right would preserve such rights and interests while stimulating the derivation of new programs from, and the development of new, applications for, preexisting works. Accordingly, the social balancing objectives of section 117, as well as the overarching goals of the copyright law, would be better achieved to the benefit of society overall.

299. See Okediji, supra note 10, at 108 ("[I]nformation technology has empowered ordinary users to become part of the creative process both by its interactive nature and the very architecture of the pennon of the information society, the Internet."); Madison, supra note 248, at 153 ("The 'personal computing' technology paradigm of the last twenty years has done much to expand the scope of individual agency in the context of law and policy. Computers help individuals to create and consume information at unprecedented scale and at unprecedented speed."); Mtima, supra note 159, at 572 ("[T] he digital revolution and similar technological advances present unheralded opportunities though which to confront [intellectual property social inequity] from a socially redeeming vantage point .... [T] he new technologies can provide the apparatus through which to achieve a more equitable distribution of the benefits of creative endeavor. In order to attain these goals, however, it is necessary to reorient our construction and application of the intellectual property law toward the aspiration of social justice."); Lessig, supra note 158, at 37 (arguing in favor of greater public freedom to make "digital reuse" of copyrighted works: "This is digital creativity. This is digital remix. ... Anybody with a $\$ 1,500$ computer can take images and sounds from the culture around us and remix them together to express ideas and arguments more powerfully than anything any of us could write as text. This is remix with more than text, yet it is the literacy of a twentyfirst century. It is what kids do with computers once they are finished hoarding all of the content that was ever produced in the history of man. When they grow bored with the hoarding, what do they do next? They find things to do with the content they've collected.... This is what they do. This is writing for them. It has extraordinary creative potential."). 